Investigation of drugs influencing the outcome of Chlamydia pneumoniae infection and the immune response induced by the pathogen

\author{
Ph.D. thesis
}

Dóra Paróczai M.D.

Supervisor: Katalin Burián M.D., Ph.D.

Doctoral School of Interdisciplinary Medicine

Department of Medical Microbiology and Immunobiology

Faculty of Medicine, University of Szeged

Szeged

2021 


\section{Table of contents}

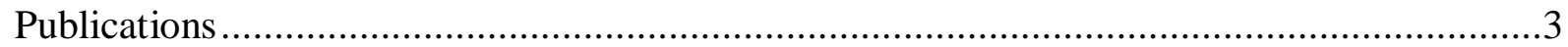

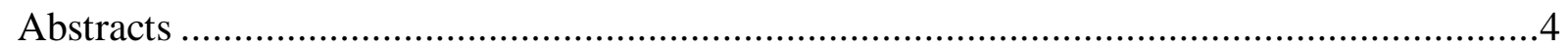

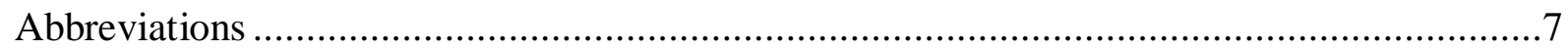

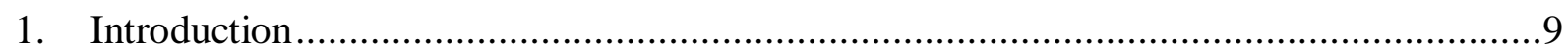

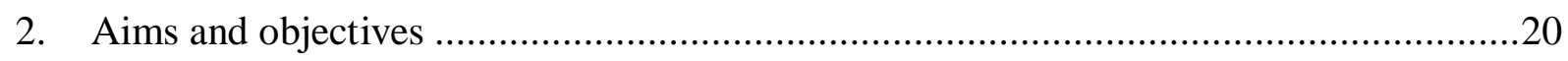

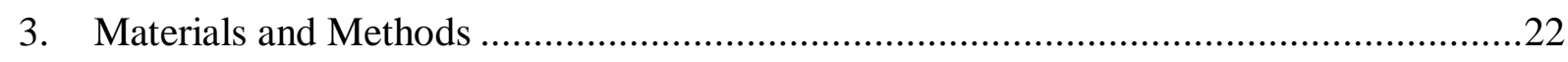

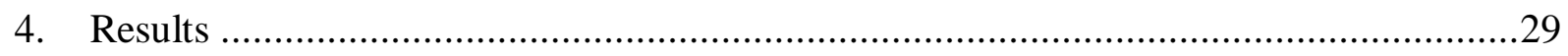

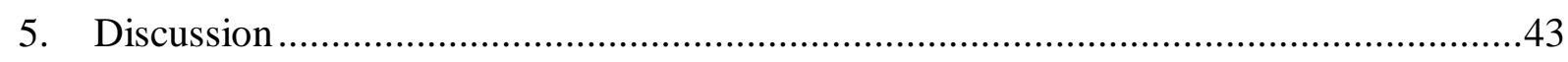

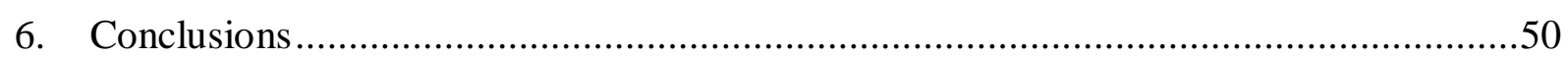

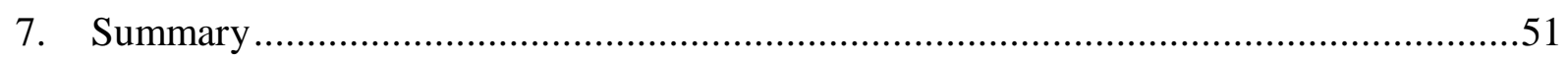

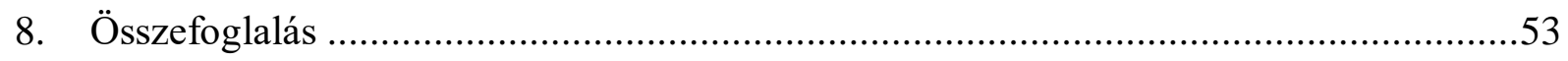

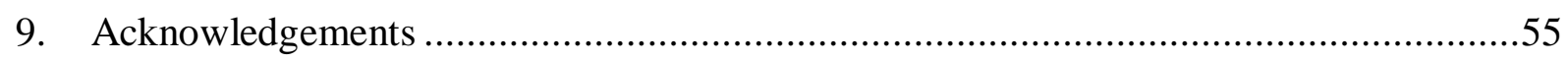

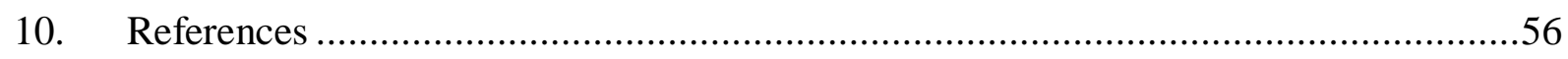

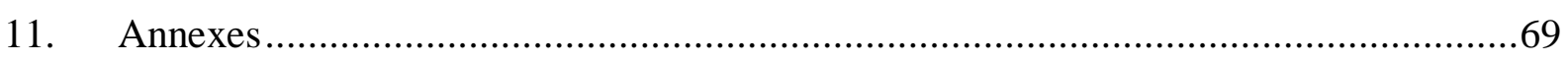




\section{Publications}

\section{Publications related to the subject of the Thesis:}

1. Dóra Paróczai, Anita Sejben, Dávid Kókai, Dezső P.Virok, Valéria Endrész, Katalin Burián:

Beneficial Immunomodulatory Effects of Fluticasone Propionate in Chlamydia pneumoniaeinfected Mice

Pathogens 2021, 10(3), 338

Impact factor: 3.018, Q1

2. Dóra Paróczai, Tímea Mosolygó, Dávid Kókai, Valéria Endrész, Dezső P. Virok, Attila Somfay, Katalin Burián:

Chlamydia pneumoniae Influence on Cytokine Production in Steroid-Resistant and SteroidSensitive Asthmatics

Pathogens 2020 Feb 11;9(2):112

Impact factor: 3.018, Q1

\section{Publications not related to the subject of the Thesis:}

1. József Furák, Dóra Paróczai, Katalin Burián, Zsolt Szabó, Tamás Zombori (shared first author):

Oncological advantage of nonintubated thoracic surgery: Better compliance of adjuvant treatment after lung lobectomy

Thorac Cancer 2020 Nov;11(11):3309-3316

Impact factor: 2.610, Q2

2. Dezso P. Virok, Tímea Raffai, Dávid Kókai, Dóra Paróczai, Anita Bogdanov, Gábor Veres, László Vécsei, Szilárd Poliska, László Tiszlavicz, Ferenc Somogyvári, Valéria Endrész and Katalin Burián:

Indoleamine 2,3-Dioxygenase Activity in Chlamydia muridarum and Chlamydia pneumoniae-Infected Mouse Lung Tissues

Front Cell Infect Microbiol 2019 Jun 12;9:192

Impact factor: 4.123, Q1 


\begin{abstract}
s
Abstracts related to the Thesis:

1. Dóra Paróczai, Dávid Kókai, Katalin Burián:

The effects of inhaled corticosteroids and a beta-2 agonist on C. pneumoniae-infected airway epithelial cells

European Respiratory Society (ERS) International Virtual Congress September 7-9, 2020
\end{abstract}

2. Paróczai Dóra, Kókai Dávid, Burián Katalin:

Inhalációs kortikoszteroidok és formoterol lokális hatásai $C$. pneumoniae fertőzött légúti eptihel sejtekben

A Magyar Tüdőgyógyász Társaság 61. Nagygyülése, Pulmonológus Kutatók Fóruma, 2020. 08.29-09.01., Budapest

3. Dóra Paróczai, Tímea Mosolygó, Dávid Kókai et al.:

C. pneumoniae serostatus influences cytokine production patterns in steroid resistant and sensitive asthmatics

European Respiratory Society International Congress, Madrid, 28 September- 2 October 2019

4. Dóra Paróczai, Tímea Mosolygó, Dávid Kókai et al.:

C. pneumoniae serostatus influences cytokine production patterns in steroid resistant and sensitive asthmatics

European Respiratory Journal 54: Suppl. 63 Paper: PA4395 (2019)

5. Dóra Paróczai, Tímea Mosolygó, Dávid Kókai et al.:

C. pneumoniae serostatus influences cytokine production patterns in steroid-resistant and -sensitive asthmatic

EU Respiratory Forum, Paris, 12-13/02/2020

6. Paróczai Dóra, Mosolygó Tímea, Kókai Dávid et al.:

Szteroid kezelésre rezisztens és szenzitív asthma bronchiale-ban szenvedő betegek perifériás mononucleáris sejtjeinek vizsgálata (2018)

Magyar Tüdőgyógyász Társaság 60. Nagygyülése, Pécs 2018.05.23-26.

7. Paróczai Dóra, Mosolygó Tímea, Kókai Dávid et al.:

Szteroid-kezelésre rezisztens és szenzitív asthma bronchialéban szenvedő betegek perifériás momonucleáris sejtjeinek vizsgálata

Medicina Thoracalis (Budapest) 71: 3 pp. 187-188. (2018) 


\section{Abstracts not related to the Thesis:}

1. Dóra Paróczai, Dávid Kókai, Áron Ulbert, Gabriella Terhes, Katalin Burián: Prevalence of Chlamydia pneumoniae antibodies in Southern Hungary

European Respiratory Society (ERS) International Virtual Congress September 7-9, 2020

2. Dávid Kókai; Dóra Paróczai; Dezső Virok; Valéria Endrész; Katalin, Burián Ambroxol possesses an antichlamydial effect in vitro and in vivo 18th German Chlamydia Workshop 2020 2020-02-05

3. Paróczai Dóra, Kókai Dávid, Ulbert Áron, Terhes Gabriella, Burián Katalin:

C. pneumoniae szeroprevalencia vizsgálata a dél-magyarországi régióban (2020)

A Magyar Tüdőgyógyász Társaság 61. Nagygyülése 2020. 08.29-09.01., Budapest

4. Kókai Dávid, Paróczai Dóra, Burián Katalin:

Egy mukolitikum in vitro és in vivo anti-chlamydiális hatással

A Magyar Tüdőgyógyász Társaság 61. Nagygyülése Pulmonológus Kutatók Fóruma 2020. 08.29-09.01., Budapest

5. Paróczai Dóra, Burián Katalin, Szabó Zsolt, Zombori Tamás, Furák József

Nem intubált thoracoscopos (NITS) lobectomia onkológiai előnye

Bronko, 2020.10.08-10. Székesfehérvár

6. Kókai Dávid, Paróczai Dóra, Virok Dezső et al.:

Viscum album tumorellenes hatásának vizsgálata

A Magyar Mikrobiológiai Társaság 2020. évi Nagygyülése és a XIV. Fermentációs Kollokvium 2020-10-14, Kecskemét

7. Dóra Paróczai, Tímea Raffai, Dávid Kókai et al.:

Expression of IDO1-2, iNOS and interferon-inducible GTPases in Chlamydia-infected murine lung

Hungarian Medical Association of America (HMAA) Summer Conference, August 3031,2019

8. Dávid Kókai, Dóra Paróczai, Dezső Virok et al.:

Growth modulating effect of Hedera helix extract on bacteria

Acta Microbiologica et Immunologica Hungarica

66 Suppl. 1 pp. 156-157., 2 p. (2019)

9. Dávid Kókai, Dóra Paróczai, Dezső Virok et al.:

Antimicrobial effect of the commonly used mucolytic agent, ambroxol

Acta Microbiologica et Immunologica Hungarica

66 : Suppl. 1 pp. 52-52. , 1 p. (2019) 
10. Dóra Paróczai, Edit Csada

Pushing the boundaries: a convincing case in treating CNS metastasis with alectinib 18th CELCC and best of WCLC November 21-23, 2019, Budapest

\section{Paróczai Dóra}

Hepaticus hydrothorax

II. Kraszkó Pál Emlékülés, Harkány, 2019.04. 26-27.

\section{Paróczai Dóra}

Hepaticus hydrothorax

Magyar Tüdőgyógyász Társaság Allergológiai és Légzéspathológiai szekciójának tudományos ülése és a fiatal pulmonológusok kazuisztikai fóruma, Hajdúszoboszló, 2019. 03.21-24.

13. Dávid Kókai, Dóra Paróczai, Dezső Virok et al.:

Antimicrobial effect of the commonly used mucolytic agent, ambroxol

A Magyar Mikrobiológiai Társaság 2018. évi Nagygyülése és a XIII. Fermentációs Kollokvium: Absztraktfüzet, (2018) p. 33

14. Paróczai Dóra, Mosolygó Tímea, Kókai Dávid et al.:

Szteroid kezelésre rezisztens és érzékeny betegek citokin profil vizsgálata $C$. pneumoniae szerostatus függvényében

PulmoAkadémia 2018. 11.16-17. Visegrád

15. Paróczai Dóra, Burián Katalin:

A D-vitamin hatása Chlamydia pneumoniae-val fertőzött egerek tüdejében Medicina Thoracalis (Budapest) 71:3 pp. 186-187. (2018) 


\section{Abbreviations}

AHR

airway hyperresponsiveness

ANOVA

Analysis of variance

BAL

bronchoalveolar lavage

BUD

budesonide

COPD

chronic obstructive pulmonary disease

Cpn

Chlamydia pneumoniae

DMSO

dimethyl sulfoxide

DPI

dry powder inhaler

EB

elementary body

ELISA

enzyme-linked immunosorbent assay

FBS

foetal bovine serum

FEF25/75

forced expiratory flow at $25-75 \%$ of the pulmonary volume

FEV1

forced expiratory volume in 1 second

FITC

fluorescein isothiocyanate

FP

fluticasone propionate

FVC

forced vital capacity

GINA

Global Initiative for Asthma

GR

glucocorticoid receptor

HDC

histidine decarboxylase

HE

haematoxylin-eosin

HFA

hydrofluoroalkane

ICS

inhaled corticosteroid

IDO

indolamine 2,3-dioxygenase

IFN

interferon

$\operatorname{IgG}$

immunoglobulin G

IL

interleukin

LPS

lipopolysaccharide 
MEM minimal essential medium

MMP-9 matrix metalloproteinase-9

MOI multiplicity of infection

$\mathrm{NF}-\kappa \mathrm{B}$ nuclear factor kappa B

PBMC peripheral blood mononuclear cell

PBS phosphate-buffered saline

PHA phytohemagglutinin

qPCR quantitative polymerase chain reaction

RB reticular body

SD standard deviation

SPG sucrose-phosphate-glutamic acid

TDO tryptophan 2,3-dioxygenase

TGF- $\beta \quad$ transforming growth factor beta

TIMP-1 tissue inhibitor of matrix metalloproteinases-1

TNF- $\alpha \quad$ tumour necrosis factor alpha

VDR vitamin D receptor 


\section{Introduction}

\subsection{General characteristics of chlamydia infections}

Chlamydiae are Gram-negative, obligate intracellular bacteria with biphasic developmental cycle which can infect wide range of host species from amoebae to humans. The genus Chlamydia currently contains nine species; however, three species (Chlamydia psittaci, Chlamydia trachomatis, and Chlamydia pneumoniae) have clinical relevance regarding human infections.

Chlamydia psittaci (C. psittaci) can infect birds, ruminants, and humans and is implicated in the so-called psittacosis, appearing as mild or severe pneumonia in humans. $C$. trachomatis serovars $\mathrm{A}, \mathrm{B}, \mathrm{Ba}$, and $\mathrm{C}$ cause trachoma, a leading cause of blindness worldwide while LGV biovar, serovars L1-3 are associated with the sexually transmitted lymphogranuloma venereum disease. Moreover, C. trachomatis serovars D-K also infect humans and cause urogenital tract infections, such as urethritis, epididymitis, or pelvic inflammatory disease, and with its chronic characteristic, they trigger fibrosis and scarring of the genital tract in women, resulting in infertility and ectopic pregnancy as well.

C. pneumoniae replicates in respiratory epithelial cells, and is responsible for community-acquired atypical pneumonia, bronchitis, pharyngitis, and sinusitis and is implicated in the development of severe asthma and acute exacerbations [1,2]. C. pneumoniae accounts for not only for acute, but also for chronic infections [3]. Thus, further investigations are needed that can contribute to a better understanding of the role of $C$. pneumoniae in chronic obstructive respiratory diseases or even lung cancer.

The Chlamydiaceae have a unique biphasic lifecycle during which they appear in two different types of developmental form: elementary body (EB) and reticulate body (RB). The smaller EBs are the metabolically inactive, extracellular forms of the pathogen that can infect the host cells. After entering the host cells, EBs containing endosomes fuse into a vesicle called inclusion. As the inclusions are formed, EBs can transform into the metabolically active, larger form of chlamydiae, termed RB. Obviously, to maintain this developmental cycle, chlamydiae require ATP, host cell metabolites, and nutrients such as amino acids, glucose, or iron. Then, RBs undergo 8-12 rounds of cell division and asynchronously differentiate back into EBs. (Figure 1) 
However, disruption of this developmental cycle can often occur. In 1961, Galasso and Manire revealed that $C$. psittaci exposed to penicillin or anti-serum $C$. psittaci transformed into a non-infectious but viable form, and when the stressors were removed, it returned to the infectious EB state [4]. Later, it was proved that under the effect of penicillin Chlamydia can transform into an enlarged, irregular form, termed an aberrant body (AB), which is in a viable but non-infectious state and can maintain persistent infections [5].

Numerous studies have revealed the complexity of the chlamydial developmental cycle and described the main stimuli in cell cultures leading to persistence and the formation of ABs. The main factors are the following: (1) penicillin exposure; (2) IFN- $\gamma$ exposure; (3) glucose, amino acid (mainly tryptophan), and iron deprivation; (4) chlamydiaphage infection; (5) exposure to cigarette smoke components; (6) co-infection with herpes simplex virus (HSV); (7) heat shock treatment; and (8) the presence of extracellular adenosine [6-11].

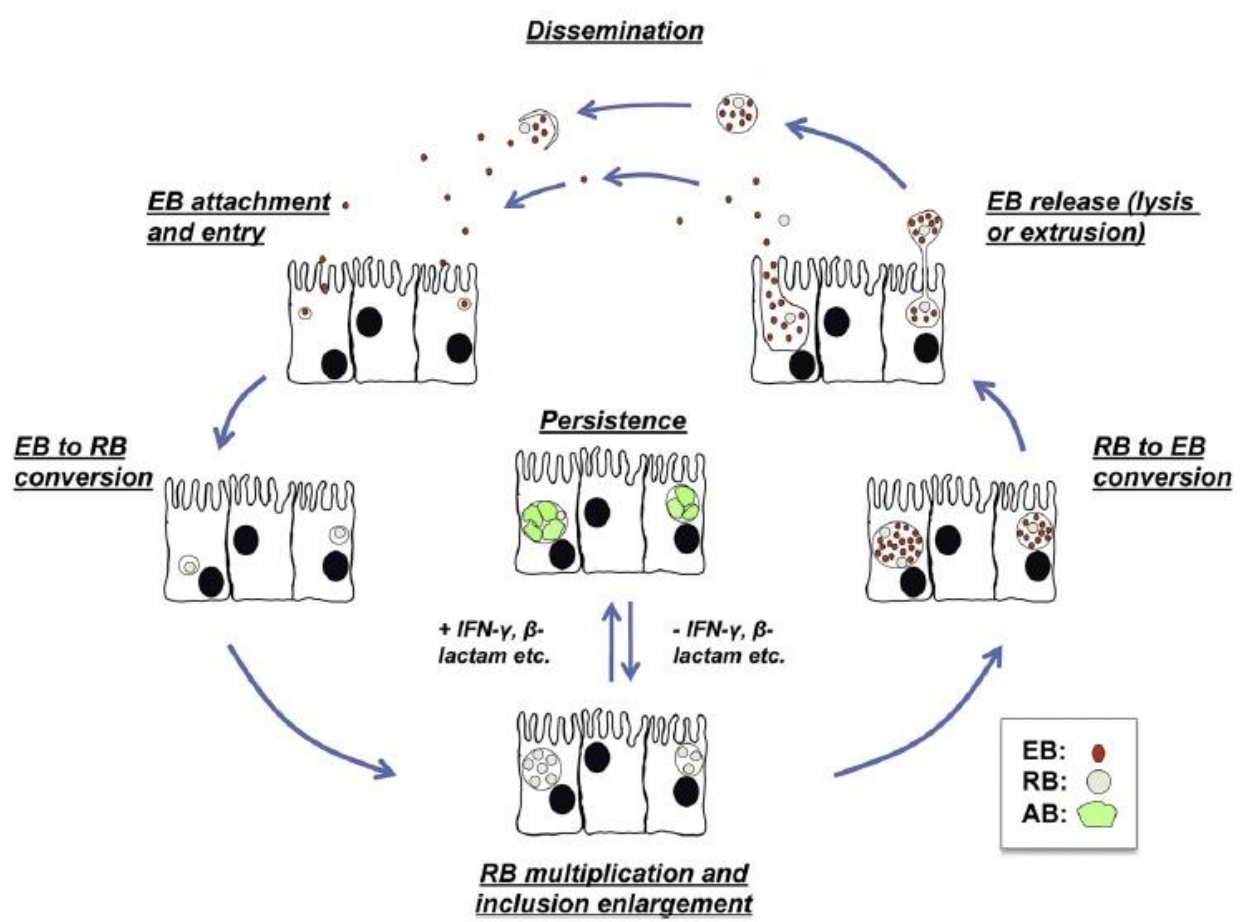

Figure 1 The developmental cycle of chlamydiae [10] 


\subsection{Potential anti-chlamydial mechanisms}

Chlamydia infections elicit predominantly cellular responses and trigger IFN- $\gamma$ production by $\mathrm{CD}^{+}$and $\mathrm{CD} 8^{+} \mathrm{T}$-cells [12-14]. IFN- $\gamma$ activates the indolamine 2,3-dioxygenase (IDO) that catabolises L-tryptophan to N-formylkynurenine, resulting in the deprivation of tryptophan. As chlamydiae are tryptophan-auxotroph bacteria, this mechanism could lead to the elimination of the infectious Chlamydia or cause a persistent state [15]. In addition, IFN$\gamma$ induces further genes involved in the elimination of chlamydiae. Consequently, IFN- $\gamma$ is one of the major intracellular defence mechanisms that has been studied since 1963 as IFN- $\gamma$ inhibited C. psittaci growth in cell cultures [16]. Furthermore, the amount of infectious $C$. psittaci also decreased in human epithelial cells exposed to IFN- $\gamma$ and the accumulation of kynurenine metabolites was also observed, suggesting that IFN- $\gamma$ enhanced IDO activity [17]. Similarly, this phenomenon was also detected in $C$. psittaci-infected human macrophages [18]. In the case of $C$. trachomatis and C. pneumoniae a restricted bacterial growth was also reported, due to the effect of IFN- $\gamma$ and tryptophan depletion $[19,20]$.

IFN- $\gamma$ is a pleiotropic cytokine secreted by T-lymphocytes and NK cells, and is involved in the regulation of host defence. A transcriptome analysis of IFN- $\gamma$-exposed, Chlamydiainfected murine epithelial cells revealed that IFN- $\gamma$ significantly enhanced the expression of Tcell chemokines, MIG/ CXCL-9, IP-10/ CXCL-10, I-TAC/CXCL-11, and increased the expression level of genes involved in the attraction or activation of neutrophils and monocytes such as MCP1, MCP-3, and IL-6 [21]. Another study demonstrated that MIG/CXCL-9 inhibited C. pneumoniae growth in vitro and in mice, the production of MIG/CXCL-9 was detected at gene expression and protein levels as well, and correlated with IFN- $\gamma$ production [22]. In addition, IFN- $\gamma$ is capable of inducing antimicrobial GTPases and iNOS, thus contributing to further anti-chlamydial mechanisms [21,23-25]. Upon IFN- $\gamma$ exposure, several key biological processes are modulated in cells infected with chlamydiae, and a range of host defence or metabolic genes are up- or downregulated, as summarized in Figure 2 [25].

IDO activity can be triggered by various factors such as IL-10, TNF- $\alpha$, IFN- $\gamma$, or oxidative stress and it plays a pivotal role in eliminating viral or bacterial infections [26]. On the other hand, IDO activity can be a burden in several cancer types, especially in non-small cell lung cancer (NSCLC) it was observed to cause metabolic vulnerabilities, distinct metabolic 
profile, and therapeutic resistance to immunotherapies; thus, IDO is also considered to be a biomarker in cancer [27].

C. pneumoniae lung infection in mice is characterized by neutrophil influx and lymphocyte infiltration; however, the role of neutrophil granulocytes in C. pneumoniae infection remains unclear [28]. It is well-established that IL-23, a member of the IL-12 family, promotes the secretion of IL-17A and IL-17F, resulting in neutrophilic inflammation and neutrophil-derived pro-inflammatory cytokine production [29]. The IL-17/IL17R axis activity can modulate the host susceptibility to Chlamydia infection in mice [30]. Moreover, a previous study demonstrated that the neutralization of IL-17A in C. pneumoniae infected mice resulted in a higher level of bacterial load, decreased neutrophil influx, and diminished cytokine levels, suggesting that IL-17A could provoke anti-chlamydial activity indirectly through initiating neutrophilic inflammation [31].

Although there are many unanswered questions in the elimination of Chlamydia in vitro and in vivo, the above-described mechanisms are investigated in Chlamydia infections to identify novel triggers of cytokine production, IDO activity, or chemokine expression, as well as to unveil further associations with the potential to inhibit Chlamydia growth. 


\section{IFN $\gamma$-induced persistence}

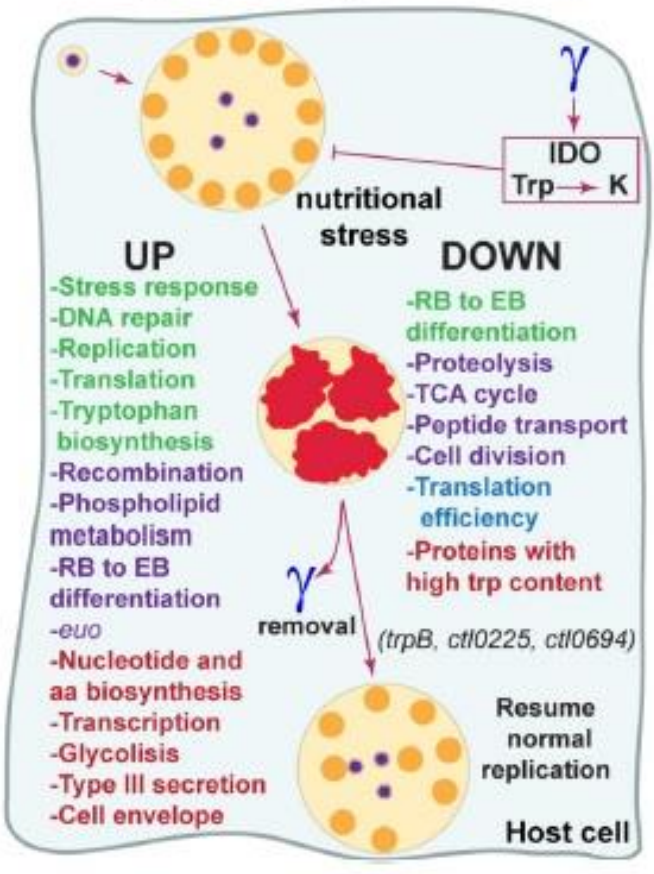

Figure 2. The model of Chlamydia evasion of antimicrobial activity under IFN- $\gamma$ exposure

IFN- $\gamma$ induces indolamine 2,3-dioxygenase (IDO) resulting in the catabolism of tryptophan (Try) into kynurenine metabolites $(\mathrm{K})$ and triggering nutritional stress to Chlamydia. In response to this stress, Chlamydia enters a persistence state that alters the main biological processes and gene expressions in the host cell to survive [25].

\subsection{The mechanism of infection-mediated asthma with focus on $C$. pneumoniae}

Asthma is a chronic airway disease associated with airway remodelling, reversible bronchial obstruction, and airway hyperresponsiveness (AHR), with $1 \%$ to $18 \%$ of the global population being affected. Asthma is a population-based clinical and economic burden with a wide variety of disease severity from mild to severe forms: $20 \%$ of the severe cases account for $80 \%$ of healthcare utilization [32]. Several triggers of asthma exacerbations are well-known; however, other factors remain elusive. Thus, unravelling the mechanisms related to asthma severity has clinical relevance, since approximately $15 \%$ of adult asthmatic patients remain uncontrolled despite their anti-inflammatory therapies [33].

C. pneumoniae is of particular interest as it is implicated in asthma pathomechanism, airway remodelling, disease severity, and treatment resistance. Over the past 20 years, 
increasing evidence have pointed to the association of $C$. pneumoniae infection with asthma. The first evidence was reported by Hahn et al. who proved that acute bronchitis, as well as wheezing and chronic asthma were caused by $C$. pneumoniae infection $[34,35]$. Clinical trials were initiated to evaluate the effect of macrolides in asthma exacerbations caused by $C$. pneumoniae, Mycoplasma pneumoniae, or both. A randomized, double-blind, placebocontrolled study proved the beneficial effects of telithromycin treatment in patients with asthma exacerbations since it resulted in a significant improvement in lung function parameters [36], although, a recent trial of azithromycin treatment of patients with acute exacerbations of asthma (AZALEA) demonstrated no results of statistical or clinical significance [37].

Evidence of the association of $C$. pneumoniae infection with asthma disease severity have accumulated since several studies reported that persistent $C$. pneumoniae infection contributes to severe, chronic asthma and is a risk factor in developing asthmatic symptoms and exacerbations [38-40]. However, the possible underlying mechanisms are still controversial. It is well-established that $C$. pneumoniae infects alveolar epithelial cells, macrophages, and even human bronchial smooth muscle cells, leading to an enhanced production of interleukin (IL)$1 \beta$, IL-6, IL-8, and tumour necrosis factor (TNF)- $\alpha$, resulting in a potential bronchial hyperreactivity and lung remodelling. Moreover, chlamydial heat shock protein 60 (cHSP60) and lipopolysaccharide (LPS) can trigger inflammation in the airways [41]. Additionally, $C$. pneumoniae induces ciliostasis, leading to an altered bacterial clearance [42].

Multiple animal model studies showed that chronic C. pneumoniae infection influences pro-inflammatory cytokine production, directly causes lung damage, indirectly affects allergic response through enhancing histidine decarboxylase (HDC) to produce histamine, and triggers the production of Chlamydia-specific IgE $[3,41]$. Horvat et al. reported that in a $C$. pneumoniaeinfected neonatal mouse model, mixed and modified T-cell responses are present, and developed the features of asthma [43]. Another study confirmed that $C$. pneumoniae-infected neonatal mice were not able to clear the infection and Chlamydia-specific IgE antibodies were persistent [44]. Collectively, these factors result in airway hyperresponsiveness, inflammatory cytokine production and altered lung immunopathology in mouse models, as summarised in Figure 3. 


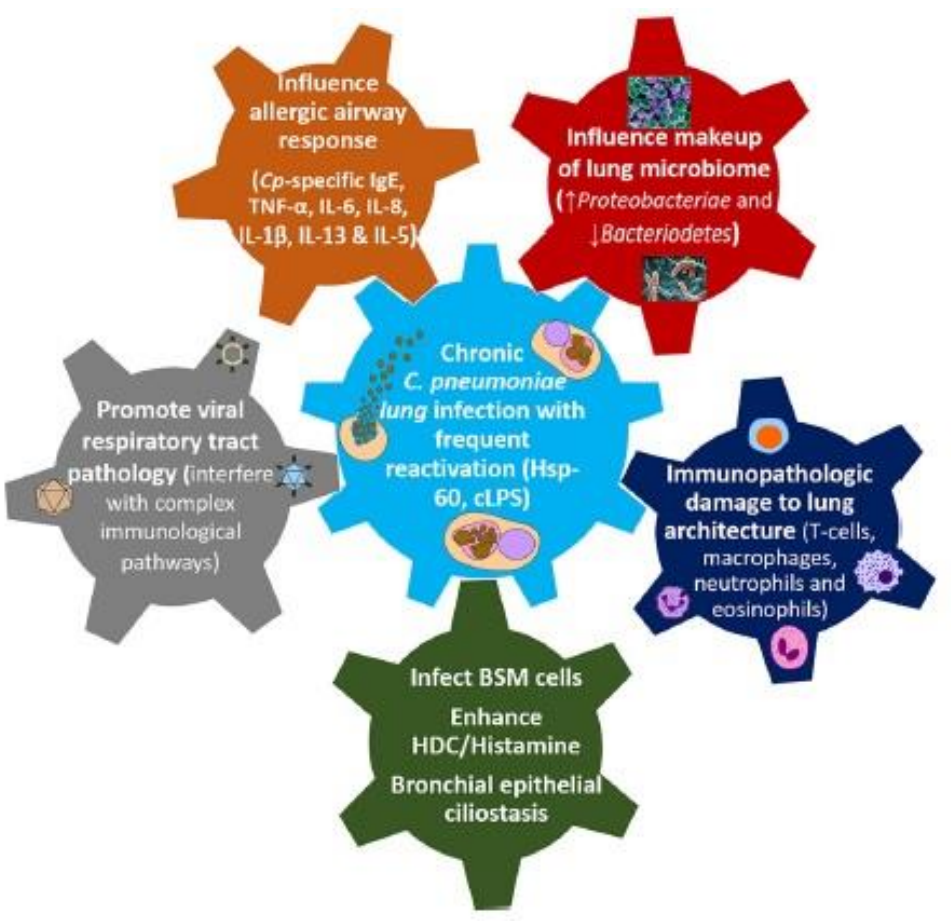

Figure 3 An overview of the role of $C$. pneumoniae infection in asthma pathogenesis [41].

Several observational studies were conducted to determine how C. pneumoniae affects the outcomes of asthma in humans. Fifty percent of the general population show C. pneumoniae IgG seropositivity at the age of 20 , and this ratio is $70-80 \%$ higher at the age of $60-70$. Most of the studies focused on the association between Chlamydia-specific serology and clinical evaluation of asthma; therefore, the results are highly dependent on the number of recruited patients, the diagnostic criteria of chronic, stable asthma, and the evaluation of the titres of $C$. pneumoniae-specific IgG, IgE, IgM, IgA, and cHSP60 antibodies [45]. Cook et al. reported fourfold higher levels of $C$. pneumoniae-specific IgG in asthmatics and found that reinfection and previous infection were significantly more common in patients with asthma [40].

A significantly higher level of $C$. pneumoniae IgA was detected in asthmatic patients (52\% vs. $15 \%$ of control subjects) and C. pneumoniae IgG was also elevated in asthmatics (18.2\%), compared to that in non-asthmatic individuals (3.0\%) [46]. IgA level against $C$. pneumoniae measured by microimmunfluorescence assay (MIF) was significantly higher in asthma and acute bronchitis, whereas cHSP60 antibodies were associated only with asthma [47]. Persistent IgA levels were related to respiratory dysfunction and the elevated IgA strongly supported the associations between chronic C. pneumoniae infection and severe asthma $[48,49]$. 
Thus, higher levels of $C$. pneumoniae antibodies provided evidence of the role of infection in the outcome of asthma [50]. Of note, serological markers also determined a decline in lung function, reflecting an enhanced airflow limitation in $C$. pneumoniae-infected patients with asthma [51].

However, C. pneumoniae can also affect cytokine responses in patients with asthma and amend therapeutic outcomes. $C$. pneumoniae can induce the secretion of IL-8, TNF- $\alpha$ in peripheral blood mononuclear cells (PBMC), enhance the NF- $\kappa \mathrm{B}$ activity, and trigger IFN- $\gamma$ responses in airway epithelial cells [52-54]. PBMCs obtained from asthmatic individuals and stimulated with $C$. pneumoniae showed a significant increase in IFN- $\gamma$, IL-4, and IgE responses compared to mock-infected cells, suggesting that $C$. pneumoniae can induce allergic responses in asthmatics [55]. Smith-Norowitz et al. also proved that lower levels of TNF- $\alpha$ were produced by the PBMCs of patients with asthma; however, this TNF- $\alpha$ production was enhanced after adding ciprofloxacin, azithromycin, or doxycycline to the infected cultures [56]. The TNF- $\alpha-$ dependent pathway contributed to increased cell proliferation in $C$. pneumoniae, suggesting a possible negative impact of $C$. pneumoniae infection on steroid treatment in asthmatics [57]. $C$. pneumoniae-induced IFN- $\gamma$ responses were also higher in PBMCs of asthmatics, compared to healthy individuals [58].

Taken together, $C$. pneumoniae affects cytokine responses in a different way in asthmatics compared to non-asthmatic subjects and serological evidence showed that previous or persistent C. pneumoniae infection leads to a decline in lung function and modulates therapeutic responsiveness to steroids. Consequently, we focused on the associations between $C$. pneumoniae infection, cytokine responses, and therapeutic outcomes.

\subsection{Corticosteroid treatment in patients with asthma and its association with respiratory infections}

Inhaled corticosteroids (ICSs) are regarded as the most effective treatment for asthma and chronic obstructive pulmonary disease (COPD) to reduce the risk of exacerbation and improve lung function, however, ICSs have been associated with an increased risk of pneumonia [59]. Earlier studies have provided controversial data about the potential risk of pneumonia in patients using ICSs and emphasise on their difference in the mechanism of action of the different types of corticosteroids [60,61]. It is well established that budesonide (BUD) and 
fluticasone propionate (FP) show differences in their pharmacokinetic, physicochemical, and even immunosuppressive properties, which can explain their distinct effects on respiratory infections and exacerbations [62,63]. As ICSs may have an anti-inflammatory effect in the course of respiratory infections, BUD and FP were studied to determine whether they can affect common viral or bacterial infections associated with COPD and asthma exacerbations. Previous studies have revealed that BUD can inhibit rhinovirus replication, and beneficially modulate cytokine responses in vitro depending on the type of the infected cell $[64,65]$. Although both BUD and FP can suppress pro-inflammatory cytokine expression, BUD had a greater impact on antimicrobial proteins [66]. Furthermore, BUD came into focus during the SARS-CoV-2 pandemic, and was examined in coronavirus $\mathrm{HCoV}-229 \mathrm{E}$ infection, where it was found to decrease the expression of the viral entry receptor and infection-induced cytokines, especially IL-6, IL-8, and IFN- $\gamma$, resulting in inhibited viral replication in vitro [67]. Transcription of genes

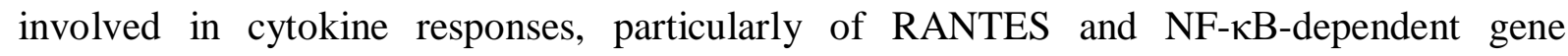
expression, is altered more extensively by FP than BUD [68].

However, it remains unclear why ICSs have different effects on the immune responses to respiratory infections. FP has been reported to cause a tenfold more potent inhibitory effect on airway immune cells and pro-inflammatory cytokine production due to its prolonged presence in the airway mucus, as compared to BUD [69,70]. Since BUD is in conjugated form intracellularly and creates a depot before it is activated [71], its effect remains unexplained in intracellular bacterial infections. In contrast to in vitro studies, BUD attenuated pulmonary antibacterial host defence and increased the number of viable bacteria in mouse lungs [72].

\subsection{Steroid-resistant asthma and its associations with $C$. pneumoniae infection}

Approximately $5 \%$ to $10 \%$ of asthmatic patients fail to fully respond to steroid therapy, and these patients also show higher mortality and morbidity rates [73]. A diagnosis of steroid resistance is established when patients exhibit $<15 \%$ improvement in the forced expiratory volume in one second (FEV1) during post-bronchodilator spirometry after 14 days of oral prednisolone therapy. Steroid resistance was first recognized in 1968 and several studies have since been performed in order to expand our understanding of the complex mechanisms resulting in steroid insensitivity [74]. Currently, there is an emerging clinical need to identify the factors contributing to the disease pathogenesis, as severely steroid-resistant asthmatic patients do not respond well to conventional therapies. A variety of factors such as infections 
and air pollution cause changes in cytokine production at the transcriptional and protein levels, leading to steroid resistance [75-77]. Several studies have confirmed that infections, particularly early-life respiratory infections, are implicated in the pathogenesis of steroidresistant asthma $[43,78,79]$. Asthmatics with earlier C. pneumoniae infection are more likely to develop steroid-resistant asthma, and their positive serostatus is associated with an increased severity of asthma and airway neutrophilia $[50,80]$.

IL-10 is an anti-inflammatory cytokine produced by regulatory T cells, macrophages, and even dendritic cells. IL-10 plays a crucial role in maintaining lung immune responses and participates in asthma pathogenesis by regulating and inhibiting Th2 responses. Asthmatic patients exhibit diminished IL-10 levels in bronchoalveolar lavage (BAL) fluid and, to the best of our knowledge, there are no congruent data about the IL-10 production by the peripheral blood cells of these patients. In addition, IL-10 secretion by circulating cells has not been investigated in relation to the use of inhaled corticosteroids $[81,82]$. IL-10 regulates responses of the immune and airway cells that are infected with $C$. pneumoniae. A former, persistent infection can affect cytokine production through enhancing Toll-like receptor (TLR) signalling and nucleotide-binding oligomerization domain-like receptor family, pyrin domain-containing 3 (NLRP3) activity. TLR2, 4 signalling, and NLRP3 activity have a connection with glucocorticoid resistance mechanisms, including changes in glucocorticoid receptor (GR) expressions and altered cytokine secretion $[83,84]$. To the best of our knowledge, no data have been published regarding the differences in cytokine production between asthmatics in association with their Chlamydia serostatus.

TNF- $\alpha$ response plays a significant role in AHR via eosinophil and neutrophil attraction, nuclear factor kappa B (NF- $\mathrm{kB})$ activation, production of adhesion molecules, and even myocyte proliferation [85]. All of these factors, along with immune and cytokine responses, can lead to the modification of GRs and changes in receptor affinity and binding capacity, resulting in reduced steroid responsiveness and a decline in lung function [86]. C. pneumoniae is able to induce TNF- $\alpha$ production and trigger cellular proliferation, leading to decreased steroid responsiveness of peripheral blood mononuclear cells (PBMCs) [57]. A previous $C$. pneumoniae infection could have a long-term effect on TNF- $\alpha$ response; hence, we investigated TNF- $\alpha$ secretion by PBMCs of Chlamydia-specific IgG-negative and -positive patients. 
Matrix metalloproteinases (MMPs) and their inhibitors are involved in the changes of the extracellular matrix and determine airway epithelium thickness. MMP-9 has a pivotal role in airway remodelling and it was the first type of MMP to be investigated in asthma. Elevated MMP levels, particularly MMP-9, are detected in the BAL fluids and even in the sera of asthmatic patients [87,88]. Rödel et al. found increased MMP-1 and -3 production due to $C$. pneumoniae infection in smooth muscle cells [89]. C. pneumoniae affects MMP-9 and tissue inhibitor of metalloproteinase-1 (TIMP-1) production by PBMCs and weakens the impact of glucocorticoids on the secretion of MMPs [90]. The levels of MMP-9 inhibitor, TIMP-1, can be altered in asthmatics; however, the relationship with infections is not well studied. Corticosteroids do not normalize the elevated MMP-9 levels [91], and MMP-9 seemed to be differentially released in exhaled condensates from asthmatics and based on this phenomenon, different biological phenotypes of asthma can be determined that can help to monitor disease severity [92].

Taken together, IL-10 and TNF- $\alpha$ cytokine production by PBMCs of steroid-sensitive and -resistant asthmatic patients have not been analysed without and with antigen stimulation in relation to their $C$. pneumoniae serostatus. As $C$. pneumoniae is involved in asthma exacerbation, as well as in persistent infections, it can have a momentous impact on the cytokine production in asthmatic patients. 


\section{Aims and objectives}

\subsection{Effects of ICS in in vitro and in vivo C. pneumoniae infection}

To our knowledge, the consequences of ICS use in C. pneumoniae infection have not been investigated yet. To address the question of whether ICS use could directly or indirectly influence $C$. pneumoniae infection, we investigated the effects of FP and BUD treatment in an infected mouse model. We hypothesised that C. pneumoniae replication and infection-induced immune responses, especially anti-chlamydial IFN- $\gamma$, and IFN-related chemokine production, IFN- $\gamma$ triggered gene expressions, could be influenced by the administration of ICSs. Since BUD and FP have different immunomodulatory effects, they can cause distinct alterations in the immune response to $C$. pneumoniae infection. To investigate this, we assessed the effects of FP and BUD on the in vitro and in vivo growth of $C$. pneumoniae.

In our study, we aimed to investigate:

- the C. pneumoniae growth after corticosteroid treatments in vitro and in vivo;

- the effects of ICSs on potential anti-chlamydial mechanisms in vivo, including the gene expression of IFN- $\gamma$, IFN- $\gamma$-inducible chemokines, IDO1, IDO2, and tryptophan 2,3dioxygenase (TDO);

- the impact of ICSs on IFN- $\gamma$, MIG/CXCL-9 production at the protein level;

- whether ICSs alter Th2 (IL-4 and IL-10) and Th17 (IL-17A) cytokine production at the protein level;

- the influence of ICSs on the expressions of receptors involved in immunomodulatory functions (vitamin D receptor (VDR) and GR).

\subsection{Differences in cytokine production of PBMCs between steroid-resistant and -sensitive asthmatics in vitro}

We hypothesised that a previous $C$. pneumoniae infection can change cytokine pattern and have an impact on subsequent IL-10 and TNF- $\alpha$ production with or without specific antigen stimulation of cells from steroid-resistant and -sensitive asthmatics. Consequently, we hypothesised that the determination of IL-10 responses in steroid-resistant and -sensitive asthmatics would disclose whether a former infection induces alterations in a different manner in asthma phenotypes. MMP-9 is implicated in the remodelling process of the lung and is 
believed to be influenced by $C$. pneumoniae infection. As there are no data available regarding MMP-9 levels in steroid-sensitive and -resistant asthmatics, we intended to investigate the MMP-9 concentration in the patients' sera according to their C. pneumoniae serostatus and steroid responsiveness.

In this study our aims were as follows:

- to define the main characteristics of steroid-resistant and -sensitive asthmatic patients, with regard to lung function testing, comorbidities, asthma medications and demographic data;

- to determine the C. pneumoniae serostatus in steroid-resistant and -sensitive asthmatics;

- to compare the IL-10 responses of PBMCs obtained from $C$. pneumoniae seropositive or seronegative steroid-resistant or -sensitive asthmatics after stimulation with $C$. pneumoniae or a polyclonal antigen;

- to compare TNF- $\alpha$ production of PBMCs obtained from $C$. pneumoniae seropositive or seronegative steroid-resistant or -sensitive asthmatics after stimulation with $C$. pneumoniae or a polyclonal antigen;

- to determine the serum MMP-9 level in C. pneumoniae seropositive or seronegative steroidresistant or -sensitive asthmatics. 


\section{Materials and Methods}

\subsection{In vitro study design}

A549 human airway epithelial cells (ATCC, Manassas, VA, USA) were transferred to a 96-well plate at a density of $4 \times 10^{4}$ cells/well in $100 \mu \mathrm{L}$ of minimal essential medium (MEM) with Earle's salts supplemented with 10\% heat-inactivated foetal bovine serum (FBS), 2 mmol/L-glutamine, 1x non-essential amino acids, $4 \mathrm{mM}$ HEPES and $25 \mu \mathrm{g} / \mathrm{mL}$ gentamycin. The cells were pre-treated and incubated for $24 \mathrm{~h}$ at $37^{\circ} \mathrm{C}, 5 \% \mathrm{CO}_{2}$ with FP (Sigma Aldrich, Saint Louis, MO, USA) or BUD (Sigma Aldrich) or left untreated. The highest non-toxic drug concentrations (FP: $3.5 \times 10^{-4} \mathrm{mM}$, BUD: $7 \times 10^{-4} \mathrm{mM}$ ) determined by the 3- (4,5dimethylthiazol -2yl)-2,5-diphenyl-2H-tetrazolium bromide (MTT) cytotoxicity test. After 24 $\mathrm{h}$ treatment, the wells were washed twice with phosphate buffered saline (PBS) and the cells were infected with $C$. pneumoniae at a multiplicity of infection (MOI) of 0.01 . The cells were inoculated in $0.5 \%$ (w/v) glucose medium, and centrifuged $(800 \mathrm{~g}, 60 \mathrm{~min})$, followed by the addition of FP or BUD to the wells. Control infected cells were left untreated. After infection, the plates were incubated at $37^{\circ} \mathrm{C}$, under $5 \% \mathrm{CO}_{2}$ for $48 \mathrm{~h}$. Subsequently, the wells were washed twice with PBS and $100 \mu \mathrm{L}$ sucrose-phosphate-glutamic acid (SPG) solution was added to each well. The plates were subjected to two freeze-thaw cycles with a quick freezing $\left(-80^{\circ} \mathrm{C}, 15\right.$ min) to obtain cell lysates, which were used directly as templates for quantitative polymerase chain reaction (qPCR). To evaluate $C$. pneumoniae propagation, direct $\mathrm{qPCR}$ was performed as described previously $[93,94]$.

\subsection{Inoculum preparation and immunostaining}

C. pneumoniae strain CWL-029, kindly gifted by Agathe Subtil (Pasteur Institute, Paris, France), was propagated on HEp-2 cells as described previously [3]. The EBs were partially purified with concentration, and subsequently aliquoted in SPG, followed by storage at $-80{ }^{\circ} \mathrm{C}$ until further use. Indirect immunofluorescence was performed to determine the concentration of infectious C. pneumoniae EBs. Serial dilutions of purified EBs were inoculated onto McCoy cell monolayers (ECACC, London UK). After incubation for $48 \mathrm{~h}$, the infected cells were fixed with acetone at $-20^{\circ} \mathrm{C}$ and stained with monoclonal anti-Chlamydia LPS antibody (AbD Serotec, Oxford, UK) and FITC-labelled anti-mouse IgG (Sigma, St. Louis, MO, USA). The number of $C$. pneumoniae inclusions was counted under a UV microscope and the titre was expressed as inclusion forming units (IFU)/mL. 


\subsection{Corticosteroid treatment in mice}

FP and BUD powder were obtained, and dimethyl sulfoxide (DMSO) was used as a vehicle for the drugs. Mice were exposed to nebulized BUD (40 $\mu \mathrm{g}, 1000 \mu \mathrm{g} / \mathrm{kg})$ and FP (25 $\mu \mathrm{g}, 625 \mu \mathrm{g} / \mathrm{kg}$ ) in an inhalation chamber for 15 min once a day, as described previously [95]. We used BUD and FP at equivalent concentrations with the ratio FP:BUD $=1: 1.6$, based on former clinical studies [96] and the higher potency of FP [68].

\subsection{Animals and experimental design}

Female BALB/c mice (6-8-weeks-old) were obtained from Charles River Laboratories (Hungary). The mice were kept under standard husbandry conditions at the animal facility of the Department of Medical Microbiology and Immunobiology, University of Szeged. Animals were fed regular mouse chow and provided with water ad libitum. The mice were randomly divided into three groups: the control, the BUD-treated and FP-treated ( $n=16$ in each group). Mice received either BUD, FP, or vehicle alone, for three days prior to infection, and then for seven days after infection. On day 3 , the mice were sedated with intraperitoneal injection of sodium pentobarbital $(200 \mu \mathrm{L}, 7.5 \mathrm{mg} / \mathrm{mL})$ and were infected with $5 \times 10^{5}$ IFU C. pneumoniae in $20 \mu \mathrm{L}$ SPG. On day 10, i.e. seven days after infection, the mice were anaesthetised and sacrificed. The lungs were removed and homogenised with acid-purified sea sand (Fluka Chemie AG, Buchs, Switzerland) using a mortar with a pestle. One half of the homogenised lungs was prepared for total RNA extraction, and the other half was suspended in $1 \mathrm{~mL}$ SPG for the detection of recoverable $C$. pneumoniae and for cytokine measurements. The experiments were implemented with the approval of the Animal Welfare Committee of the University of Szeged, Hungary and conformed to the Directive 2010/63/EU.

\subsection{Culturing of $C$. pneumoniae from the lungs}

One half of the homogenised lungs was centrifuged (10 $\mathrm{min}, 400 \mathrm{~g}$ ) and serial dilutions of the supernatants were inoculated onto McCoy cell monolayers and centrifuged (60 min, 800g). The number of recoverable $C$. pneumoniae inclusions was determined by indirect immunofluorescence as described earlier, and expressed in terms of IFU/mL.

\section{6. mRNA extraction and cDNA synthesis}

Total RNA was extracted from the other half homogenised lung tissues of the control $(n=12)$, as well as BUD- and FP-treated mice ( $n=12$ for each group) using TRI reagent (Sigma) 
according to the manufacturer's protocol. Total RNA concentrations and purity were measured using a NanoDrop spectrophotometer (Thermo Scientific, Waltham, MA, USA). First-strand cDNA was synthesised from $2 \mu \mathrm{g}$ of total RNA using Maxima First Strand cDNA Synthesis $\mathrm{Kit}$, and $20 \mathrm{pM}$ random hexamer primer in $20 \mu \mathrm{L}$ reaction buffer according to the manufacturer's protocol (Thermo Fisher Scientific Inc. Waltham, MA, USA).

\section{7. $\mathrm{qPCR}$ validation}

qPCR was performed in a Bio-Rad CFX96 real-time system with SsoFast ${ }^{\mathrm{TM}}$ EvaGreen ${ }^{\circledR}$ qPCR Supermix (Bio-Rad, Hercules, CA, USA) master mix and murine specific primer pairs. The sequences of used murine specific primers for qPCR are shown in Table 1. Cycle threshold (Ct) values were calculated for $\beta$-actin, IDO1, IDO2, TDO, IFN- $\gamma$, MIG/CXCL9, IP10/CXCL10, ITAC/CXCL11, VDR, and GR, and the relative gene expression levels were determined by the $2^{-(\Delta \Delta \mathrm{Ct})}$ method. The relative expression level was indicated as $2-(\Delta \Delta \mathrm{Ct})$, where $\Delta \Delta \mathrm{Ct}=\Delta \mathrm{Ct}$ for the experimental sample $-\Delta \mathrm{Ct}$ for the control sample. 


\begin{tabular}{|c|c|}
\hline Murine specific primers & Sequence \\
\hline$\beta$-actin sense & 5'-TGGAATCCTGTGGCATCCATGAAAC-3' \\
\hline$\beta$-actin antisense & 5'-TAAAACGCAGCTCAGTAACAGTCCG-3' \\
\hline IDO1 sense & 5'-GCTTCTTCCTCGTCTCTCTATTG-3' \\
\hline IDOI antisense & 5'-TCTCCAGACTGGTAGCTATGT-3' \\
\hline IDO2 sense & 5'-CCTGGACTGCAGATTCCTAAAG-3' \\
\hline IDO2 antisense & 5'-CCAAGTTCCTGGATACCTCAAC-3' \\
\hline TDO sense & 5'-GGCATGGCTGGAAAGAACAC-3' \\
\hline TDO antisense & 5'-CTCCCTGGAGTGCACGGTAT-3' \\
\hline$I F N-\gamma$ sense & 5'-CAAGTGGCATAGATGTGGAAGA-3' \\
\hline IFN- $\gamma$ antisense & 5'-GCTGTTGCTGAAGAAGGTAGTA-3' \\
\hline MIG/CXCL9 sense & 5'-ACGTAGGTTTCGAGACCAGGGATT-3' \\
\hline MIG/CXCL9 antisense & 5'-CAACACCAAGTGTTCTGCCACCAA-3' \\
\hline IP10/CXCL10 sense & 5'-TGGCTAGTCCTAATTGCCCTTGGT-3' \\
\hline IP10/CXCL10 antisense & 5'-TCAGGACCATGGCTTGACCATCAT-3' \\
\hline ITAC/CXCL11 sense & 5'-TACCCGAGTAACAGCTGCGACAAA-3' \\
\hline ITAC/CXCL11 antisense & 5'-TATGAGGCGAGCTTGCTTGGATCT-3' \\
\hline VDR sense & 5'-TACACCCCCTCACTGGACATGAT-3' \\
\hline VDR antisense & 5'-CGATGACCTTTTGGATGCTGTAA-3' \\
\hline GR sense & 5'-GTTCCTAAGGAAGGTCTGAAGAG-3' \\
\hline GR antisense & 5'-CAATTCTGACTGGAGTTTCC-3' \\
\hline
\end{tabular}

Table 1. Murine specific primer pairs used for $q P C R$ 


\subsection{Lung histology}

Microscopic examination of the lungs of infected control, as well as BUD- and FP-treated mice ( $n=4$ from each group) was performed. After the removal of the lungs, tissues of individual mice were immediately placed into plastic tubes, pre-filled with $10 \%$ formalin, resulting in 1:10 of tissue:formalin ratio. During dissection, tissue samples in the tube were cut into $1 \mathrm{~mm}$ slices and embedded into paraffin blocks. Four-micrometre sections were cut, and regular haematoxylin-eosin (HE) staining was performed. All tissue sections were examined by light microscopy.

\subsection{Preparation of the $C$. pneumoniae antigen}

C. pneumoniae CWL29 (ATCC, US) elementary bodies (EBs) were purified from infected Hep2 cells (ECACC, London, UK) by density gradient centrifugation and inactivated with formaldehyde treatment, as described by Penttila et al. [97]. The protein content of the antigen was measured by spectrophotometry, and the antigen was stored at $-80^{\circ} \mathrm{C}$ until use.

\subsection{Separation and stimulation of PBMCs}

PBMCs from $10 \mathrm{~mL}$ heparinized blood were separated using Ficoll gradient (Sigma), 5 $\times 10^{5}$ cells in three parallel wells were incubated in the presence of $2 \mu \mathrm{g} / \mathrm{mL}$ C. pneumoniae antigen or $10 \mu \mathrm{g} / \mathrm{mL}$ polyclonal mitogen (phytohemagglutinin, PHA) or left untreated in 200 $\mathrm{mL}$ RPMI medium containing $10 \%$ foetal bovine serum supplemented with glutamine, nonessential amino acids, gentamycin, and fluconazole. Supernatants of the stimulated wells were harvested $48 \mathrm{~h}$ after treatment, aliquoted, and stored at $-80{ }^{\circ} \mathrm{C}$ until performing the cytokine ELISA.

\subsection{C. pneumoniae-specific enzyme-linked immunosorbent assay}

C. pneumoniae-specific antibodies from the patients and the controls were detected using the "NovaLisa TM Chlamydia pneumoniae" enzyme-linked immunosorbent assay [ELISA] kit (Nova Tec Immundiagnostica GmbH, Germany). Fifty-fold diluted sera were tested in duplicate in accordance with the manufacturer's instructions for the presence of $C$. pneumoniae-specific IgG.

\subsection{Cytokine and chemokine measurements from the lungs, supernatants of PBMCs and patients' sera}

The supernatants of homogenised lung tissues were centrifuged $(12000 \mathrm{~g}, 5 \mathrm{~min})$ and ELISA for IFN- $\gamma$, IL-4, IL-10, IL17-A, MIG/CXCL-9 was performed according to the manufacturers' instructions. MIG/CXCL-9 concentration was determined using a mouse 
MIG/CXCL-9 ELISA Kit (Sigma Aldrich), and IL-17A was measured using Quantikine mouse IL-17 immunoassay (R\&D Systems, Minneapolis, MN, USA). IFN- $\gamma$, IL-4 and IL-10 concentrations were detected with Invitrogen mouse ELISA kits (Thermo Fisher Scientific Inc., Waltham, MA, USA). Sensitivity for IFN- $\gamma$, IL-4, IL-10, IL-17A and MIG/CXCL-9 measurements ranged between $15-2000$ pg/mL, 4-500 pg/mL, 32-4000 pg/mL, $10.9-700$ pg/mL and $2.741-2000 \mathrm{pg} / \mathrm{mL}$, respectively.

The supernatants of the stimulated or untreated PBMCs obtained from patients, were centrifuged (5 min, $1200 \mathrm{rpm}$ ) and assayed for the concentrations of IL-10 and TNF- $\alpha$ using Human Mini ELISA Development cytokine kits (PeproTech), while the quantity of MMP-9 in the sera was determined using the human MMP-9 ELISA kit (Sigma). The sensitivities of the IL-10, TNF- $\alpha$ and MMP-9 measurements were in the range of 23 to 3000,16 to 2000 , and 8.23 to $6000 \mathrm{pg} / \mathrm{mL}$, respectively. The clarified supernatants and sera were tested in duplicate in accordance with the manufacturer's instructions.

\subsection{Study population and participants}

Eighty adult patients with asthma were recruited from the outpatient departments and inpatient wards at the Department of Pulmonology (University of Szeged, Hospital of Chest Diseases, Deszk). The inclusion criteria included clinically stable asthma, persistent asthma symptoms, inhaled steroid use, absence of current exacerbation, and complete follow-up periods. The exclusion criteria included a history of HIV infection, current viral or bacterial infections, chronic immunosuppression or autoimmune disease, cancer, systemic intravenous corticosteroid use (in the past 30 days), and antibiotic treatment (in the past 30 days). As a control group, 40 non-asthmatic, healthy blood donors without obstructive lung diseases, nasal polyposis, allergic rhinoconjunctivitis, cancer, chronic heart disease, autoimmune diseases, and immunosuppression were selected. Patients' demographic and clinical characteristics were recorded. To investigate cytokine production, $5 \mathrm{~mL}$ native and $5 \mathrm{~mL}$ unfractionated heparin anticoagulated blood samples were collected from each patient. Before collecting blood samples from the patients with asthma, post-bronchodilator tests were performed. After administering $400 \mu \mathrm{g}$ inhaled salbutamol, dynamic lung volumes (the FEV1, forced vital capacity [FVC], FEV1/FVC, and forced expiratory flow at $25 \%$ to $75 \%$ of the pulmonary volume [FEF25/75]) were measured. Spirometry was carried out using a Carefusion MasterScreen Body Plethysmograph (Sentrysuite software 2.13). 
Asthmatic and control patients were not involved in the development, implementation, and interpretation of the study. Our study was undertaken in accordance with the Regional Human Biomedical Research Ethics Committee, University of Szeged (WHO-3220, 77/2013, 27/05/2013). Patients received written and verbal information about the purpose of blood sampling. All patients volunteered and their written informed consents were obtained.

\subsection{Statistical analysis}

Statistical analysis of data was performed with GraphPad Prism 8.0.1. software, using one-way and two-way ANOVA, and Kruskal-Wallis test. All post hoc comparisons were performed using Tukey's method. Further statistical analysis of the patient data was carried out using SigmaPlot for Windows Version 11.0 software, using the Wilcoxon-Mann-Whitney twosample test. Data are expressed as mean \pm standard deviation (SD). Differences at $p<0.05$ were considered statistically significant. 


\section{Results}

\section{1. $\quad$ FP suppressed $C$. pneumoniae replication in A549 cells}

We tested $C$. pneumoniae-infected A549 cells to investigate whether FP or BUD treatment could modulate bacterial growth. As shown earlier, assessment of chlamydial genome concentration by direct qPCR correlated with manual fluorescent microscopic quantitation, wherein qPCR was used to measure the concentration of chlamydia in infected cells [93]. We assessed C. pneumoniae growth in FP- and BUD-treated epithelial cells based on the cycle threshold $(\mathrm{Ct})$ values. FP treatment resulted in significantly higher $\mathrm{Ct}$ values, indicating suppressed $C$. pneumoniae growth, compared to that measured in BUD-treated (32.35 \pm 0.51 vs. $30.81 \pm 0.55, p<0.01)$ and untreated control $(32.35 \pm 0.51$ vs. $31.41 \pm 0.39, p<0.01)$ cells. BUD

treatment did not affect $C$. pneumoniae growth significantly (Figure 4). Given that our in vitro observations could have significant clinical relevance, we next addressed the elucidation of possible immunomodulatory effects of FP and BUD in mice to explore the underlying mechanisms.

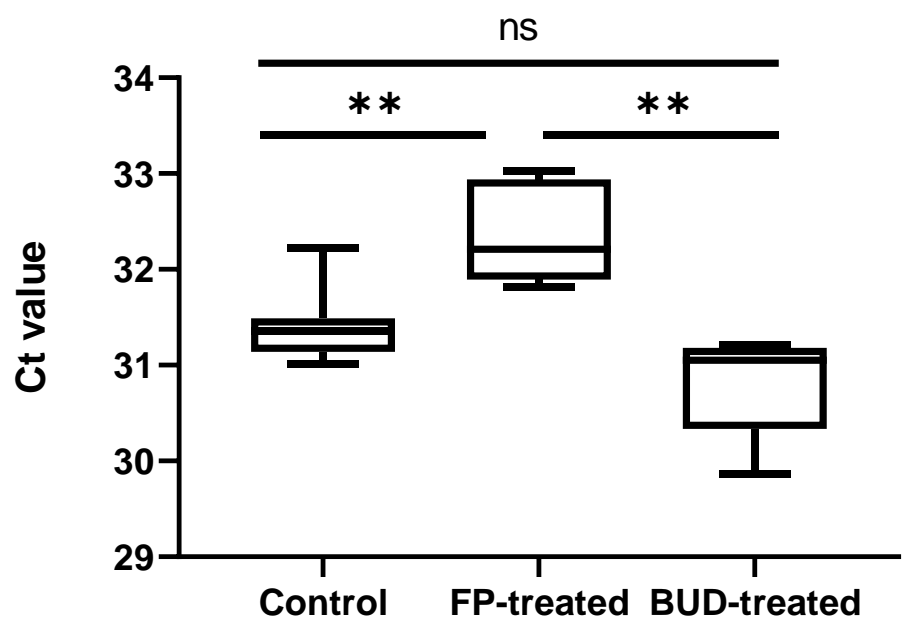

Figure 4. C. pneumoniae growth in A549 cells treated with BUD or FP.

A549 cells were treated with BUD or FP for $24 \mathrm{~h}$ before, and for $48 \mathrm{~h}$ after infection with $C$. pneumoniae (0.01 MOI). Growth of $C$. pneumoniae was estimated by direct qPCR, as described in the Materials and Methods section. The concentration of $C$. pneumoniae is shown in terms 
of $\mathrm{Ct}$ value. Error bars denote the mean $\pm \mathrm{SD}$ of five parallel cultures. Asterisks indicate significant differences, $* * p<0.01$, ns means not significant difference.

\section{2. $\quad$ FP inhibited $C$. pneumoniae growth in the lungs of mice}

We found that the viable number of $C$. pneumoniae was significantly lower in FP-treated mice compared to the control group $\left(5.33 \times 10^{4} \pm 3.42 \times 10^{4}\right.$ IFU/mL vs. $1.13 \times 10^{5} \pm 1.28 \times 10^{5}$ IFU/mL, $p<0.0001$ ) (Figure 5). A similar trend was observed upon comparing FP-treated mice with BUD-treated mice $\left(5.33 \times 10^{4} \pm 3.42 \times 10^{4} \mathrm{IFU} / \mathrm{mL}\right.$ vs. $1.15 \times 10^{5} \pm 1.42 \times 10^{4} \mathrm{IFU} / \mathrm{mL}$, $\mathrm{p}<0.001)$. In contrast, no inhibition was detected in BUD-treated mice compared to the control (Figure 5).

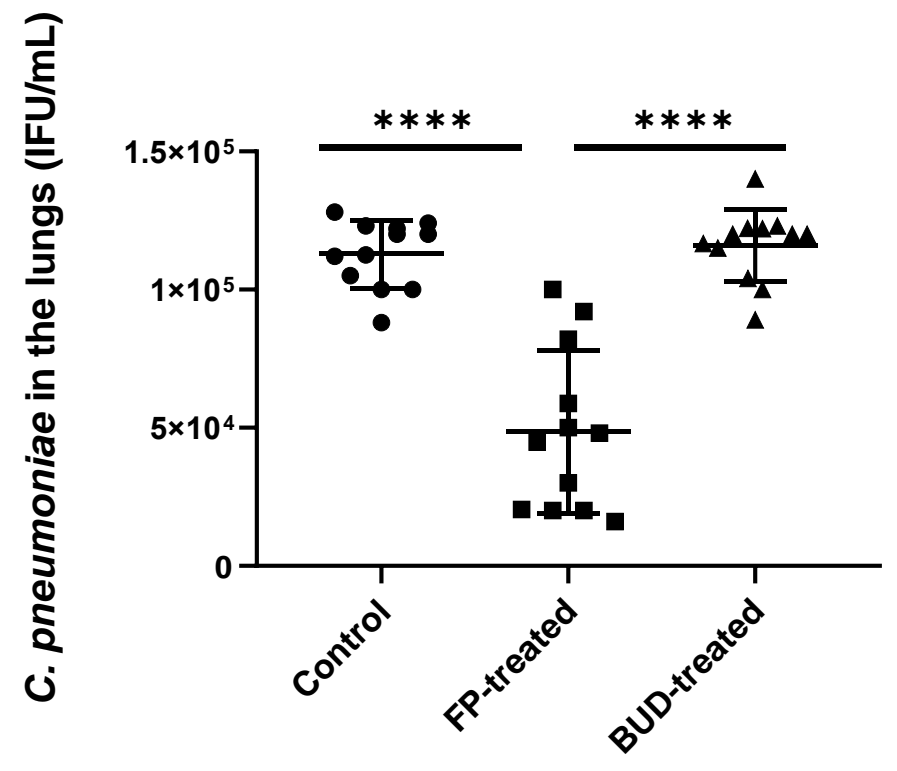

Figure 5. Quantity of recoverable C. pneumoniae in mouse lungs.

Supernatants of lung homogenates were cultured on McCoy cells, and the number of recoverable $C$. pneumoniae was counted by indirect immunofluorescence test after two days of incubation. Symbols show data from individual mice. Horizontal lines indicate mean \pm SD. Significant differences are indicated by asterisks, $* * * * p<0.0001$.

\subsection{Effects of FP and BUD on chlamydia-infected lung tissue histopathology}

In the haematoxylin-eosin (HE)-stained mouse lung tissues, a distinctive difference in the general blueish appearance of the background in the control and BUD-treated specimen was observed, which was caused by extensive lymphoid infiltration. Even though the inflammation appeared diffusely, accentuated perivascular and peribronchial infiltration was observed at high 
magnification (Figure 6A, B). Similarly, in the FP-treated mouse lung tissues, lymphocytic and plasmacytic infiltration was observed; centriacinar emphysema was also visible, with thin alveolar septa (Figure 6C).

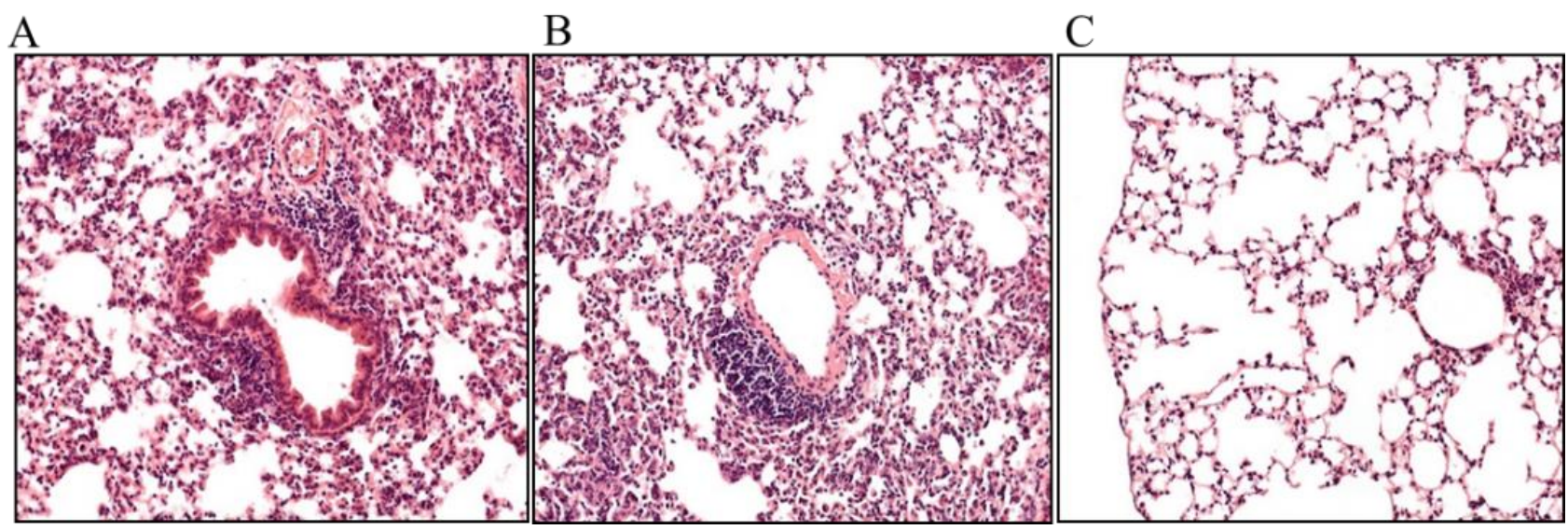

Figure 6. The effects of ICSs on Chlamydia-induced histopathology in BALB/c mouse lung tissues.

Representative HE-stained sections of $C$. pneumoniae-infected, untreated (A), C. pneumoniaeinfected, BUD-treated (B), and C. pneumoniae-infected, FP treated (C) lung tissues (magnification $200 \mathrm{x}$ ).

\subsection{Effects of FP and BUD treatment on gene expressions related to IFN- $\gamma$ and corticosteroid responses in $C$. pneumoniae infected mice}

Next, we explored whether the expression of IFN- $\gamma$ and IFN- $\gamma$ induced genes was altered in FP- and BUD-treated lung tissues, including the typical, inducible defence genes against chlamydia infection, such as IDO1, IDO2, MIG/CXCL9, IP-10/CXCL10 and I-TAC/CXCL11. qPCR using total RNA isolated from homogenised lung tissues revealed that the relative expression of IFN- $\gamma$ was significantly enhanced in FP-treated mice $(p<0.001)$ compared to BUD-treated and control mice, the relative expression was $12.8 \pm 5.8$ vs. $0.9 \pm 0.43$, and $12.8 \pm 5.8$ vs. $0.75 \pm 0.1$, respectively (Figure 7A).

Our previous studies showed that the IFN- $\gamma$ inducible IDO1 and IDO2 are highly expressed in C. pneumoniae infected mouse lungs [98]. Thus, we next investigated the effects of FP and BUD treatment on the expression of IFN- $\gamma$ inducible IDO1, IDO2 and TDO involved 
in the metabolism of amino acid tryptophan that is essential for chlamydia growth. Our results indicated a significantly increased IDO2 expression in the FP-treated mice, compared to the control and BUD-treated group $(p<0.05)$. This phenomenon was not observed in IDO1 and TDO expression (Figure 7B).

To test the consequence of increased IFN- $\gamma$ release, we determined the relative expression levels of IFN- $\gamma$ related chemokines. Unexpectedly, we found that BUD significantly decreased the expression of MIG/CXCL9 ( $p<0.05)$ and IP-10/CXCL10 $(p<0.01)$, compared to untreated C. pneumoniae infected control mice. However, the relative expression of MIG/CXCL9 and IP-10/CXCL10 was not altered significantly in FP-treated mice. I-TAC/CXCL11 showed similar expression levels in all groups (Figure 7C).

Further, we investigated the expression of glucocorticoid receptor (GR) and Vitamin D receptor (VDR) genes, as both receptors perform immunomodulatory functions $[99,100]$. Interestingly, our results demonstrated that FP treatment increased VDR expression significantly, compared to control and BUD-treated mice $(p<0.01)$, whereas BUD treatment did not affect VDR expression. We found no statistically significant difference in GR expressions in C. pneumoniae-infected BUD- and FP-treated mice (Figure 7D). 

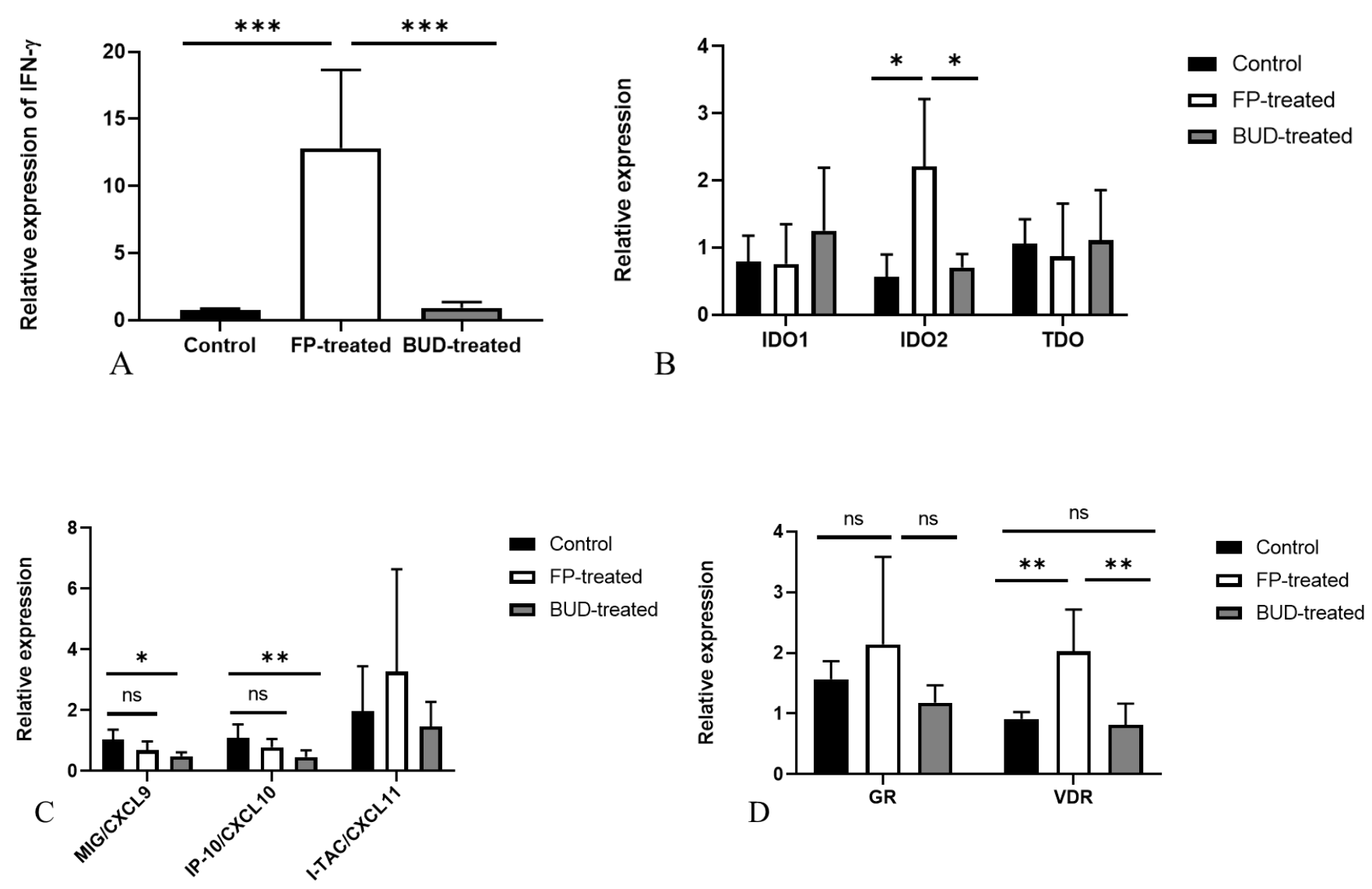

Figure 7. Relative gene expressions in C. pneumoniae-infected and treated mouse lungs.

Gene expression of IFN- $\gamma$ (A), IDO1, IDO2, TDO (B), IFN- $\gamma$-inducible chemokines (C), VDR and GR (D) determined by qPCR. Relative expression was normalized to $\beta$-actin gene expression, and calculated by the $2^{-(\Delta \Delta \mathrm{C} t)}$ method. Significant differences are indicated with asterisks, ${ }^{*} p<0.05, * * p<0.01, * * * p<0.001$, ns means not significant difference.

\subsection{Anti-chlamydial IFN- $\gamma$ and MIG/CXCL9 protein production are enhanced by FP treatment}

As previously described, IFN- $\gamma$ exhibits crucial anti-chlamydial activity by inducing chemokine production and increasing anti-chlamydial gene expression [101]. To determine whether ICSs altered gene expression, and influenced the levels of IFN- $\gamma$ and related chemokines, we estimated IFN- $\gamma$ and MIG/CXCL-9 protein concentrations in the supernatants of lung homogenates for C. pneumoniae-infected mice (Figure 8). According to our results, IFN- $\gamma$ production was significantly increased after FP treatment, compared to untreated infected 
control (4519.77 $\pm 1289.08 \mathrm{pg} / \mathrm{mL}$ vs. $2060.07 \pm 995.76 \mathrm{pg} / \mathrm{mL}, p<0.05)$. BUD treatment did not affect IFN- $\gamma$ production significantly compared to FP-treated or control mice.

We examined whether MIG/CXCL9 production at the protein level was changed in association with alterations in IFN- $\gamma$ production in vivo. We found that FP-treated mice showed a higher protein level of MIG/CXCL9, compared to that in untreated controls $(4984 \pm 1137$ $\mathrm{pg} / \mathrm{mL}$ vs. $1169 \pm 1178 \mathrm{pg} / \mathrm{mL}, p<0.01)$. Further, a significant increment in the level of MIG/CXCL9 was detected in FP-treated lung tissues, compared to the BUD-treated mouse lungs (4984 \pm 1137 pg/mL vs. $1370 \pm 1509$ pg/mL, $p<0.01)$ (Figure 8).

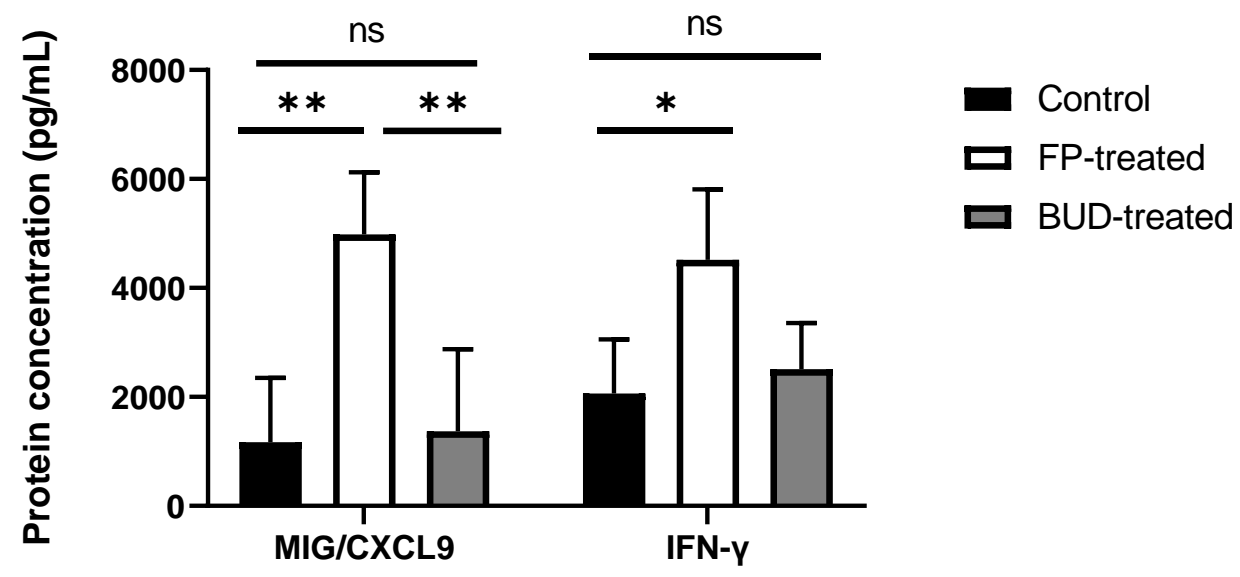

Figure 8. Effect of ICSs on IFN- $\gamma$ and MIG/CXCL9 production in C. pneumoniae-infected mouse lungs.

IFN- $\gamma$ and MIG/CXCL9 protein concentrations were determined by ELISA in the supernatants of homogenised lung tissues of infected FP- and BUD-treated, and untreated mice. Data are shown as $\mathrm{pg} / \mathrm{mL}$. Bars denote mean $\pm \mathrm{SD}$ of each group $(\mathrm{n}=12)$. Significant differences are indicated with asterisks, ${ }^{*} p<0.05$, ${ }^{* *} p<0.01$, ns means not significant difference.

\subsection{Effects of BUD and FP treatment on the secretion of Th17 and Th2 cytokines in C. pneumoniae-infected lung tissues}

ELISA of supernatants from control and treated lung samples was performed to elucidate the influence of ICS treatment on cytokine production. As previously reported by us, IL-17A has an indirect anti-chlamydial activity in vivo [31]. Thus, we investigated the impact of ICSs 
on IL-17A production in infected mouse lungs (Figure 9A). We found a significantly elevated IL-17A level in FP-treated mouse lungs, compared to the control group $(55.59 \pm 17.7 \mathrm{pg} / \mathrm{mL}$ vs. $3.06 \pm 0.67 \mathrm{pg} / \mathrm{mL}, p<0.01)$. Although increased IL-17A production was observed in BUDtreated mice, it did not differ significantly from the control and FP- treated mice.

As Th2 cytokines play a pivotal role in modulating lung inflammation, we evaluated whether FP and BUD could affect IL-4 and IL-10 secretion in C. pneumoniae-infected mice (Figure 9B). Our results indicated unaltered IL-4 production, whereas IL-10 levels changed in a different manner. We detected a significantly higher amount of IL-10 in FP-treated lung tissues, but not in the BUD-treated lungs, in comparison with the untreated infected mice (1757.28 $\pm 602.93 \mathrm{pg} / \mathrm{mL}$ vs. $739.67 \pm 19.70 \mathrm{pg} / \mathrm{mL}, p<0.05)$.

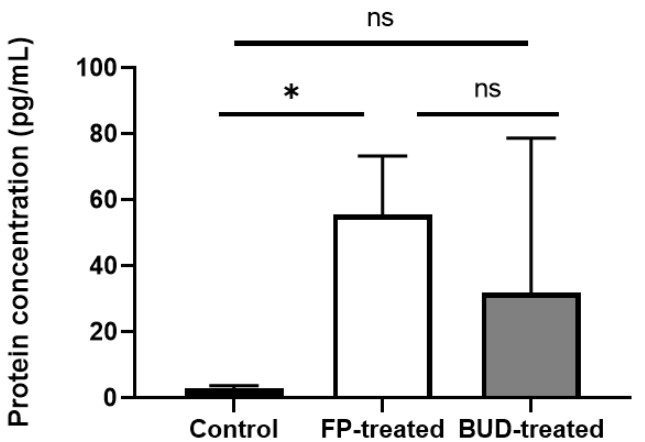

A

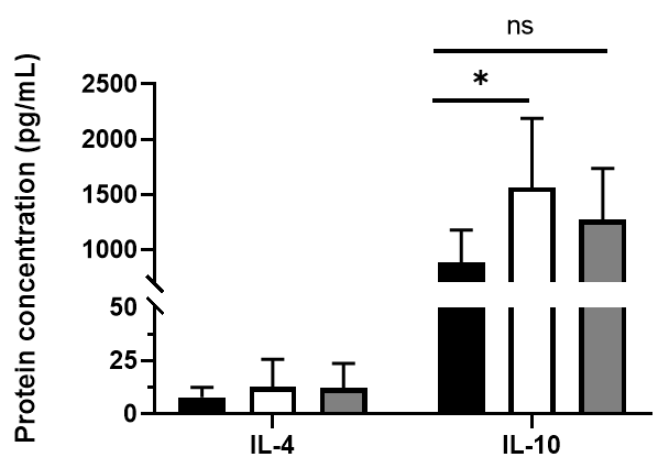

B

Figure 9. Effects of BUD and FP on the secretion of IL-17A, IL-4 and IL-10 in control and treated mice.

IL-17A (A), IL-4 and IL-10 (B) protein concentrations were determined by ELISA in the supernatants of homogenised lung tissues of infected FP- and BUD-treated, and untreated mice. Bars denote mean $\pm \mathrm{SD}$ of each group $(\mathrm{n}=12) .{ }^{*} p<0.05$, ns means not significant difference.

\subsection{Patient characteristics and demographics}

In our further study we aimed to investigate whether PBMCs obtained from steroidresistant and -sensitive patients show different cytokine production depending on the $C$. pneumoniae serostatus of asthmatic patients. Thus, 40 steroid-sensitive asthmatic patients (65\% female, $35 \%$ male, with a mean age of 59 years) and 40 steroid-resistant asthmatic patients 
(68\% female, $32 \%$ male, with a mean age of 63 years) were enrolled. Steroid resistance was defined by the following criterion: Patients did not achieve $>15 \%$ improvement in the FEV1 value after 14 days of oral prednisolone (40 mg/day) therapy. In accordance with our expectations, the steroid-resistant group exhibited significant differences in dynamic lung volumes (Table 2). The steroid-resistant group had a mean FEV1 value of $56 \% \pm 0.2 \%$, with a significant difference as compared with the sensitive group with a mean FEV1 value of $72 \% \pm$ $0.22 \%(p=0.01)$. The ICSs used were budesonide/formoterol dry powder inhaler (daily doses ranging from 400 to $1280 \mu \mathrm{g}$ ), cyclesonide hydrofluoroalkane (HFA) (daily doses ranging from 320 to $640 \mu \mathrm{g}$ ), fluticasone propionate/salmeterol HFA (daily doses ranging from 500 to 1000 $\mu \mathrm{g}$ ), and beclomethasone dipropionate/formoterol HFA (daily doses ranging from 400 to 1000 $\mu \mathrm{g})$. In the sensitive group, $50 \%$ of patients received high daily ICS doses, while in the resistant group, 95\% of patients used high dose ICS. Steroid doses were determined according to the GINA guideline [73]. Further clinical characteristics of asthmatic patients are provided in Table 2. As controls, 40 non-asthmatic, healthy blood donors were selected. 


\begin{tabular}{|c|c|c|c|}
\hline & $\begin{array}{l}\text { Steroid-sensitive } \\
\mathrm{n}=\mathbf{4 0}\end{array}$ & $\begin{array}{l}\text { Steroid-resistant } \\
n=40\end{array}$ & $\begin{array}{l}p \\
\text { value }\end{array}$ \\
\hline Mean age (median) & $59(63)$ & $63(67)$ & 0.13 \\
\hline Gender & $\begin{array}{l}\text { male: } 14(35 \%), \\
\text { female: } 26(65 \%)\end{array}$ & $\begin{array}{l}\text { male: } 13(32 \%), \\
\text { female: } 27(68 \%)\end{array}$ & - \\
\hline Smoking, mean py & $\mathrm{n}=15(24,5)$ & $\mathrm{n}=19(31)$ & 0.14 \\
\hline Smoking status & $\begin{array}{l}\text { Never: } 25 \\
\text { Previously: } 7 \\
\text { Habitual: } 8\end{array}$ & $\begin{array}{l}\text { Never: } 21 \\
\text { Previously: } 10 \\
\text { Habitual: } 9\end{array}$ & \\
\hline $\begin{array}{l}\text { Atopic subjects (allergic rhinitis, sinusitis, } \\
\text { nasal polyposis) }\end{array}$ & $\mathrm{n}=22(55 \%)$ & $\mathrm{n}=25(63 \%)$ & - \\
\hline CHD & $\mathrm{n}=2(5 \%)$ & $\mathrm{n}=17(42 \%)$ & - \\
\hline Blood eosinophilia & $\mathrm{n}=11(27 \%)$ & $\mathrm{n}=17(42 \%)$ & 0.319 \\
\hline FEV1 $(\mathbf{L}, \%)$ & $2.1 \pm 0.8(72 \pm 0.2)$ & $1.4 \pm 0.6(56 \pm 0.2)$ & 0.01 \\
\hline FEV1 reversibility rate (mean, \%) & $15.2 \pm 2.6$ & $12.6 \pm 3.3$ & 0.41 \\
\hline $\operatorname{FVC}(\mathrm{L}, \%)$ & $3.3 \pm 1.1(92.8 \pm 24)$ & $2.5 \pm 0.9(79.9 \pm 21)$ & 0.03 \\
\hline FEV1/FVC (\%) & $65.4 \pm 11.3$ & $60.1 \pm 14.8$ & 0.09 \\
\hline FEF25/75 (L/s) & $1.4 \pm 0.8$ & $0.8 \pm 0.4$ & 0.004 \\
\hline BMI $\left(\mathrm{kg} / \mathrm{m}^{2}\right)$ & $29.4 \pm 8.1$ & $27.6 \pm 5.1$ & 0.3 \\
\hline Asthma medications & $\begin{array}{l}\text { ICS: } 8 \text { patients } \\
\text { ICS/LABA: } 32 \\
\text { patients } \\
\text { SABA: } 28 \text { patients } \\
\text { LTI: } 20 \text { patients }\end{array}$ & $\begin{array}{l}\text { ICS/LABA: } 40 \\
\text { patients } \\
\text { LAMA: } 8 \text { patients } \\
\text { SABA: } 31 \text { patients } \\
\text { LTI: } 27 \text { patients }\end{array}$ & \\
\hline
\end{tabular}

$\overline{\text { Table 2. Main clinical characteristics and demographic data of the steroid sensitive and steroid- }}$ resistant patients.

BMI, body mass index; CHD, coronary heart disease; FEF 25/75, forced expiratory flow at 25\% to $75 \%$ of the pulmonary volume; FEV1, forced expiratory volume in $1 \mathrm{~s}$; FVC, forced vital capacity; ICS; inhaled corticosteroid; LABA, long-acting $\beta$-agonist; LTI, leukotriene inhibitor; py, pack year; SABA; short-acting $\beta$-agonist. 


\subsection{C. pneumoniae-specific serological status of asthmatic patients}

First, we assayed the serum samples for the presence of $C$. pneumoniae-specific IgG to determine the seropositivity rate in each group. The control group representing the average Hungarian population exhibited a $67 \%$ seropositivity rate. Surprisingly, we observed a lower C. pneumoniae seropositivity rate in asthmatic patients than among the controls. In asthmatic patients, $42 \%$ of steroid-sensitive and $47 \%$ of steroid-resistant participants were $C$. pneumoniae IgG-positive (Figure 10).

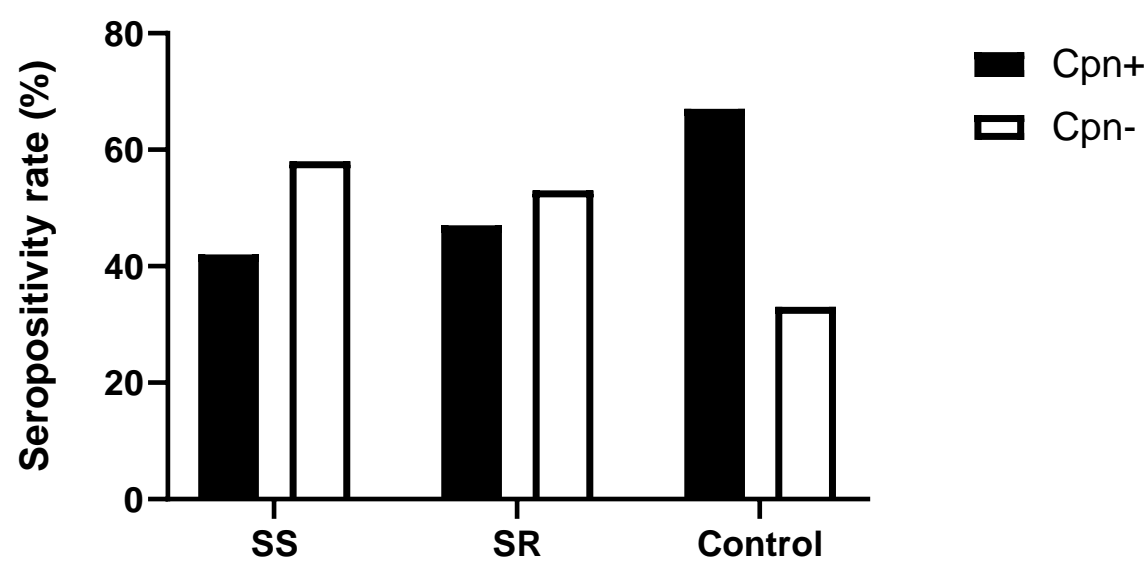

Figure 10. C. pneumoniae serostatus of healthy blood donors (controls) and patients with asthma.

C. pneumoniae serostatus was determined by an ELISA from the native blood samples from controls and steroid-sensitive (SS) and steroid-resistant (SR) asthmatics (C. pneumoniae seropositive (Cpn+) and C. pneumoniae seronegative (Cpn-)).

\subsection{IL-10 Cytokine production in asthmatics in response to specific ( $C$. pneumoniae)} and nonspecific phytohemagglutinin (PHA) stimulation

PBMCs obtained from steroid-resistant and -sensitive asthmatics were cultured with the C. pneumoniae antigen or phytohemagglutinin (PHA); or were untreated. Untreated PBMCs from $C$. pneumoniae seropositive, steroid-sensitive patients secreted a significantly higher amount of IL-10 than did those from the $C$. pneumoniae positive non-asthmatic blood donors $(0.17 \pm 0.06 \mathrm{ng} / \mathrm{mL}$ versus $0.03 \pm 0.01 \mathrm{ng} / \mathrm{mL}, p=0.04)$. The same tendency was observed in the seropositive steroid-resistant group, as their PBMCs spontaneously produced a higher 
amount of IL-10 than did those of seropositive non-asthmatic blood donors $(0.41 \pm 0.07 \mathrm{ng} / \mathrm{mL}$ versus $0.03 \pm 0.01 \mathrm{ng} / \mathrm{mL}, p=0.0002$ ) (Figure 11A).

Moreover, significantly higher IL-10 production was detected without stimulation in $C$. pneumoniae seropositive, steroid-resistant patients than in steroid-sensitive patients $(0.41 \pm$ $0.07 \mathrm{ng} / \mathrm{mL}$ vs. $0.17 \pm 0.06 \mathrm{ng} / \mathrm{mL}, p=0.002)$ (Figure 11A).

Interestingly, when the PBMCs from $C$. pneumoniae seropositive individuals were cultured with $C$. pneumoniae antigen or PHA, no significant difference was observed between the asthmatic groups and the control group related to IL-10 production (Figure 11A).

Concerning steroid resistance, we compared IL-10 production in C. pneumoniae seropositive and seronegative asthmatics. We found that in cases of seropositivity, steroidresistant patients exhibited significantly higher spontaneous IL-10 cytokine release than did seronegative individuals $(0.41 \pm 0.07 \mathrm{ng} / \mathrm{mL}$ vs. $0.25 \pm 0.14 \mathrm{ng} / \mathrm{mL}, p=0.02)$. Moreover, after specific $C$. pneumoniae antigen stimulation, significantly higher IL-10 levels were found in the seropositive steroid-resistant group than in the seronegative steroid-resistant group $(0.59 \pm 0.18$ $\mathrm{ng} / \mathrm{mL}$ vs. $0.34 \pm 0.13 \mathrm{ng} / \mathrm{mL}, p=0.02$ ). Regarding the cytokine response to nonspecific PHA stimulation, we observed no differences related to the $C$. pneumoniae serostatus among steroidresistant asthmatics (Figure 11B). 


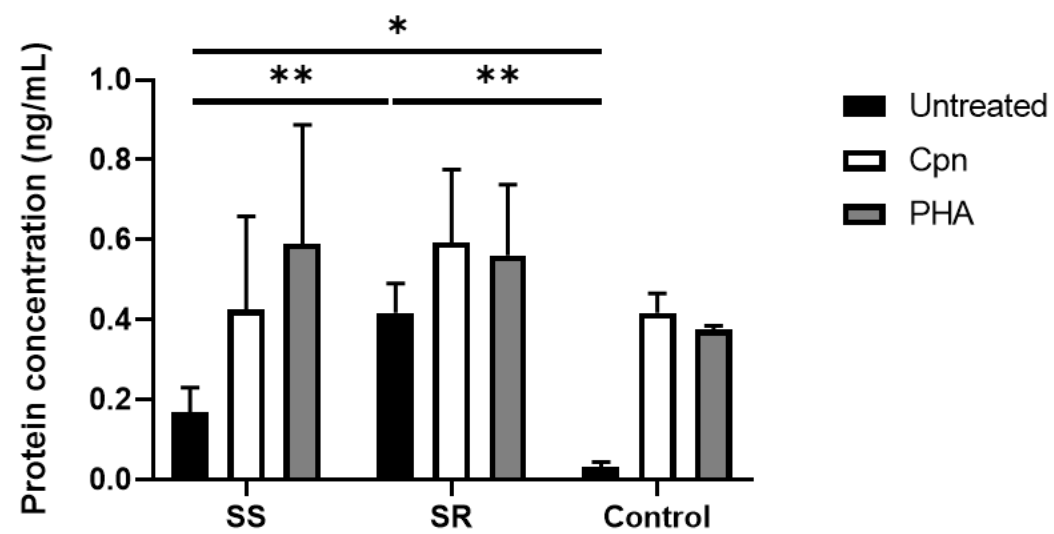

A

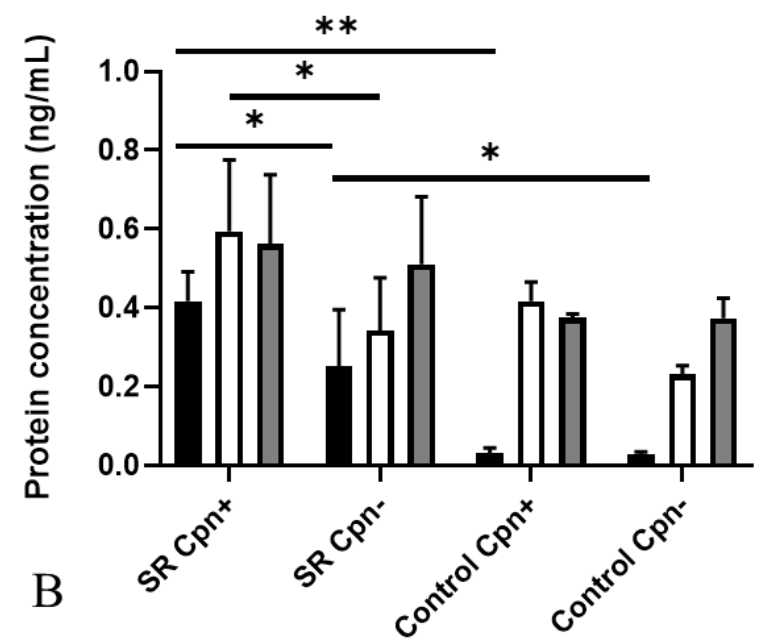

Untreated

ש Cpn

ㅁ PHA

Figure 11. Effect of stimulation with $C$. pneumoniae and phytohemagglutinin (PHA) on interleukin (IL)-10 secretion.

Human peripheral blood mononuclear cells (PBMCs) were obtained from steroid-resistant (SR) and steroid-sensitive (SS) asthma patients and healthy blood donors (controls) with $C$. pneumoniae seropositivity ( $\mathrm{Cpn}+)$ and seronegativity (Cpn-) as follows:

(A) IL-10 concentrations were determined by ELISA and expressed as $\mathrm{ng} / \mathrm{mL}$ (mean $\pm \mathrm{SD}$ ) in the $C$. pneumoniae seropositive groups.

(B) IL-10 production by PBMCs of $C$. pneumoniae seropositive and seronegative SR patients as compared with controls (mean $\pm \mathrm{SD}$ ). Asterisks indicate significant differences ${ }^{*} p<0.05$, $* * p<0.01)$. 


\subsection{TNF- $\alpha$ production in asthmatics in response to specific $(C$. pneumoniae $)$ and nonspecific PHA stimulation}

PBMCs obtained from asthmatics and cultured without stimulation produced a higher amount of TNF- $\alpha$ than did those from non-asthmatics, however these differences did not reach significance. PBMCs from $C$. pneumoniae seropositive steroid-resistant participants spontaneously secreted a higher level of TNF- $\alpha$ than did seropositive steroid-sensitive patients $(0.23 \pm 0.16 \mathrm{ng} / \mathrm{mL}$ vs. $0.08 \pm 0.06 \mathrm{ng} / \mathrm{mL}, p=0.05)($ Figure 12).

In response to specific and nonspecific treatments, in C. pneumoniae seropositive asthmatics there was no significant difference in the secreted TNF- $\alpha$ levels between the steroidsensitive and -resistant groups.

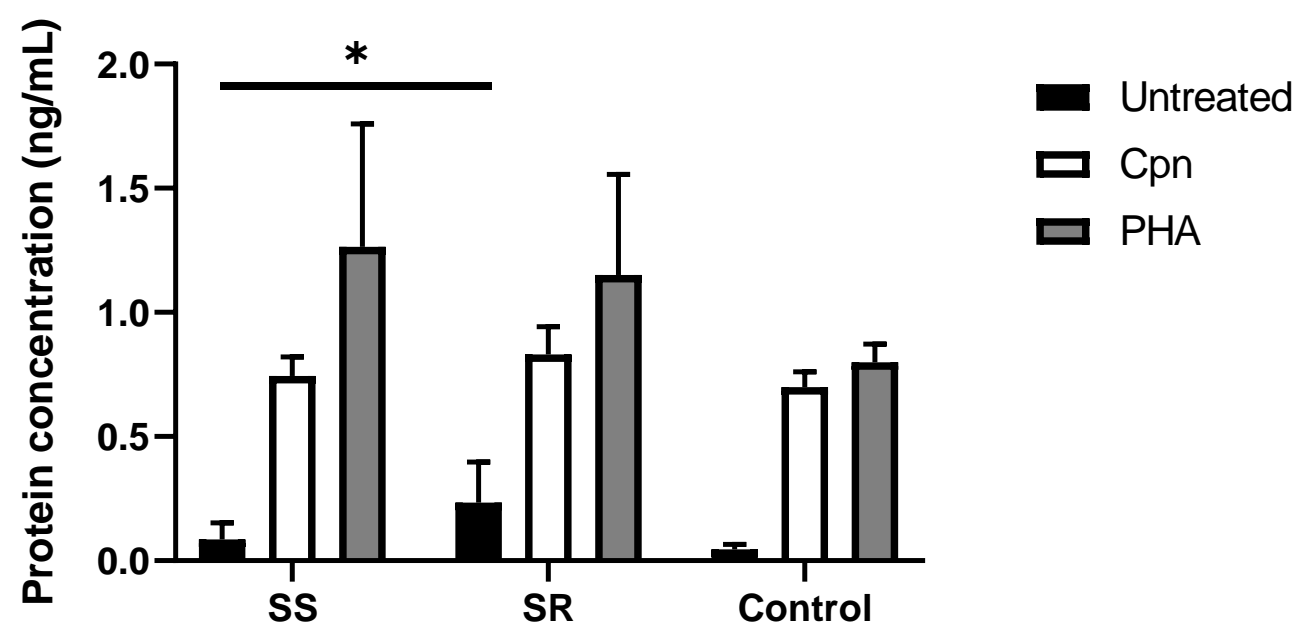

Figure 12. C. pneumoniae and PHA induced TNF- $\alpha$ production of PBMCs from seropositive control and asthmatic participants.

Tumor necrosis factor-alpha (TNF- $\alpha$ ) content of the supernatants of peripheral blood mononuclear cells (PBMCs) from seropositive steroid-sensitive (SS) and steroid-resistant (SR) asthmatic patients and healthy blood donors (controls). TNF- $\alpha$ concentrations were determined by ELISA and expressed as $\mathrm{ng} / \mathrm{mL}$ (mean $\pm \mathrm{SD}$ ). Significant differences are labelled with asterisks, $* p<0.05$.

\subsection{MMP-9 production in steroid-sensitive and steroid-resistant asthmatic patients}

The serum level of MMP-9 was measured in C. pneumoniae seropositive and seronegative steroid-sensitive and steroid-resistant asthmatics. A significant difference in the serum MMP-9 level was observed among the steroid-resistant participants. C. pneumoniae 
seronegative patients exhibited significantly increased serum levels of MMP-9 as compared with those found in $C$. pneumoniae seropositive asthmatics ( $p=0.01,1.46 \pm 1.124 \mathrm{ng} / \mathrm{mL}$ vs. $0.528 \pm 0.193 \mathrm{ng} / \mathrm{mL}$ ) However, this difference was not observed among steroid-sensitive patients. In association with $C$. pneumoniae seronegativity, a statistically significantly higher MMP-9 level was found in the sera of steroid-resistant patients than in steroid-sensitive patients $(1.46 \pm 1.125 \mathrm{ng} / \mathrm{mL}$ vs. $0.87 \pm 0.49 \mathrm{ng} / \mathrm{mL}, p=0.04)$ (Figure 13).

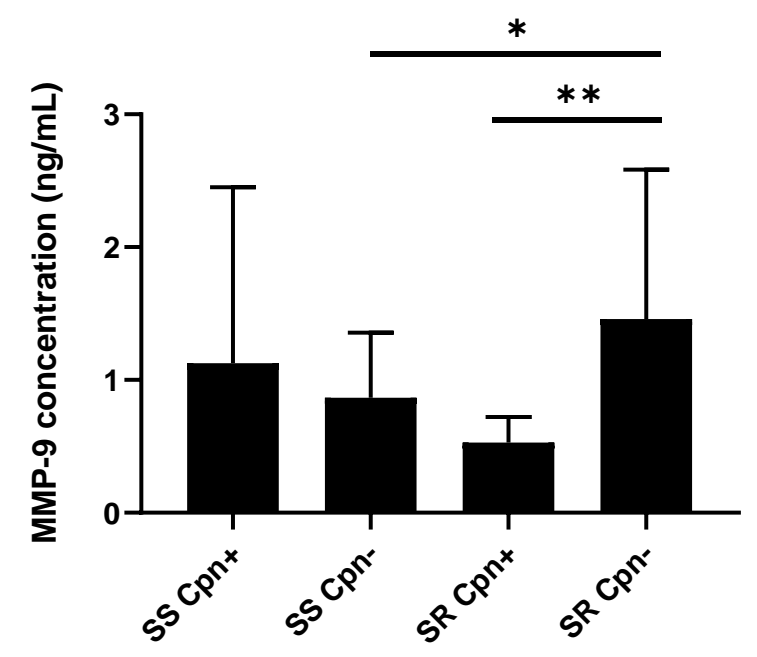

Figure 13. Serum matrix metalloproteinase (MMP)-9 levels in patients with asthma.

MMP-9 levels were measured in steroid-sensitive (SS) and steroid-resistant (SR) $C$. pneumoniae seropositive $(\mathrm{Cpn}+)$ and seronegative $(\mathrm{Cpn}-)$ asthmatic patients by ELISA. Data are expressed as $\mathrm{ng} / \mathrm{mL}$ (mean $\pm \mathrm{SD}$ ). Significant differences are labelled with asterisks, ${ }^{*} p<$ 0.05 and $* * p=0.01$ 


\section{Discussion}

\subsection{The effects of ICSs on $C$. pneumoniae infection in vitro and in mice}

ICSs are widely used to treat COPD and asthma, as they show a broad range of antiinflammatory properties and improve lung function. However, the association between ICS use and the risk of pneumonia remains unclear, as different ICSs have distinct effects on infections. Several studies have been conducted to reveal their possible connection to respiratory infections; nevertheless, clinical data tend to be contradictory $[60,102,103]$. ICSs have different pharmacological and immunomodulatory effects considering responses to viral infections, immune cell functions, and cytokine production [62]. As exacerbations of obstructive lung diseases are mainly caused by viral or bacterial infections, ICSs were investigated from a new perspective and their effects on antimicrobial defence were examined.

FP and BUD affected pro-inflammatory epithelial responses, and presented antiviral and anti-inflammatory activities differentially. In vitro studies have shown that BUD is effective in counteracting rhinovirus replication, inhibiting cytokine production, and enhancing antimicrobial protein secretion; however, in vivo, it suppressed pulmonary host defence genes that are essential for bacterial clearance $[64,72,104,105]$. Moreover, inhalation of BUD has been shown to lead to significant alterations in the regulation of anti- and pro-inflammatory genes involved in eliminating respiratory pathogens [106].

FP is regarded as a more potent inhibitor of pro-inflammatory genes and cytokines, although it can preserve the production of several cytokines, especially IFN- $\gamma$, to reverse its exaggerated effect on $\mathrm{Th} 2$ response in allergic inflammation. Inhibitory effects of this topically active ICS are not well-established in respiratory infections, despite the fact that FP is far more potent in cytokine production than other ICSs [107].

C. pneumoniae is implicated in asthma exacerbations, and there is increasing evidence indicating that it plays a role in asthma pathogenesis, leading to altered cytokine responses, decreased lung function, and heightened disease severity [50,56,108]. Thus, we aimed to investigate whether ICSs could have beneficial modulatory effects on chlamydia infection in vitro and in vivo, and thus, define the possible underlying mechanisms. 
Collectively, our reported data inspire several exciting concepts that could have practical outcomes for respiratory physicians. Our in vitro results suggested that $C$. pneumoniae growth is suppressed in infected epithelial cells by FP, but not by BUD. Thus, we tested our hypothesis whether FP could inhibit the growth of $C$. pneumoniae in vivo. We found that the number of recoverable $C$. pneumoniae decreased in $C$. pneumoniae-infected mouse lungs after FP treatment, as observed in A549 epithelial cells. It is well established that the IFN- $\gamma$ is the main regulator of chlamydia elimination, and can trigger various mechanism leading to chlamydia inhibition. IFN- $\gamma$ exposure induced IDO activity which is responsible for tryptophan degradation. As chlamydiae are tryptophan auxotrophs, increased IDO activity results in a restricted chlamydia growth in vitro and in vivo [17,98]. Moreover, IFN- $\gamma$ enhances the expression of genes involved in innate immunity, thus, contributing further to the mechanisms inhibiting chlamydia infections [97]. Our findings revealed that FP can significantly induce IFN- $\gamma$ not only at the transcription level, but also at the protein level, in contrast to BUD, indicating the previously described phenomenon that FP preserves IFN- $\gamma$ responses [107]. IFN$\gamma$ associated MIG/CXCL9 was shown to have antimicrobial effect to $C$. pneumoniae [100], similar to C. trachomatis and C. muridarum [97]. Our results demonstrated that MIG/CXCL9 levels increased at the protein level in parallel with IFN- $\gamma$ after FP administration, compared to that in untreated control and BUD-treated mouse lungs. Interestingly, FP did not alter the expression of other IFN- $\gamma$-inducible chemokines, suggesting that other mechanisms may be playing a role in chemokine expression. Notably, BUD treatment significantly reduced the gene expression levels of the CXCL-10 and CXCL-11, which is in accordance with a previous report [109]. Consistently, ICS treatments have a unique impact on IFN- $\gamma$ response and chemokine production.

IDO activity is a hallmark of tryptophan depletion and suppression of chlamydia growth in cell cultures and mice. Further, IDO activity is associated with several pulmonary diseases, including lung cancer [110]. Sputum IDO activity was enhanced in an IL-10 dependent manner in asthmatic patients receiving ICSs; the ICSs increased IL-10 secretion from macrophages in parallel with IDO activity, indicating that ICS use could generate IDO activity through IL-10 production [111]. Our results also indicate a significant increase in IL-10 production after FP administration in infected mice; conversely, BUD did not have an enhancing effect. Since it is 
well-known that FP can increase local secretion of IL-10 in vivo [112], we concluded that the observed IDO activity could have been derived from the additive effects of IFN- $\gamma$ and IL-10.

To further analyse the production of anti-chlamydial cytokines, we measured IL-17A levels, as it has been reported to trigger neutrophil recruitment in the lung, whereas its neutralisation results in a higher $C$. pneumoniae burden [31]. FP was not able to inhibit IL-17A, in contrast to BUD, which downregulates IL-23, the potential inducer of IL-17A [113,114]. Our current findings revealed that FP-treated mice produced significantly higher amounts of IL-17A in response to $C$. pneumoniae infection, suggesting that this increase in IL-17A production might also result in the development of $C$. pneumoniae inhibition, as observed in a previous study, IL17A can synergize with IFN- $\gamma$, playing a protective role in chlamydia infection [115].

Lastly, we analysed the relative expression of GR and VDR, and found that FP treatment significantly increased VDR expression compared to control and BUD-treated mice. VDR is one of the highly downregulated transcription factors in chlamydia-infected murine cells [97], suggesting that the elevated VDR expression in our study was due to the influence of FP in mice. This result raises the likelihood of the beneficial impact of FP to stem from VDR activation; a former study proved that the diminished VDR activity was associated with higher chlamydia load in the lungs [116]. Vitamin D favours the curtailment of bacterial infections, and had several implications in modulating adaptive and innate immunity to eliminate bacterial infections [117]. Therefore, our results raise the possibility that FP supports VDR functions, which can further influence cytokine and chemokine production. Thus, we recommend further examination of the interaction between ICS use and VDR activity, as Vitamin D supplementation is widely recommended in asthma.

In addition, we investigated whether FP or BUD could amend the histopathology of $C$. pneumoniae-infected mouse lungs and found that all specimens contained lymphocyte infiltration as a sign of $C$. pneumoniae infection. However, emphysema was also visible in FPtreated lung samples. As FP treatment showed an exaggerated IFN- $\gamma$ response to the chlamydia infection, the elimination of $C$. pneumoniae through enhanced cytokine and chemokine production could lead to minimal emphysema in infected lungs. According to previous studies $[118,119]$, emphysema can be associated with the IFN- $\gamma$ production and chlamydia infections. 
To our knowledge, this is the first study that investigated the effects of FP and BUD on C. pneumoniae infection in vivo and in vitro. The most notable results of our research are as follows:

(1) FP treatment inhibited C. pneumoniae growth in A549 cells; (2) FP also inhibited $C$. pneumoniae replication in vivo; (3) FP induced IFN- $\gamma$ at gene expression and protein level, leading to an enhanced IDO activity and MIG/CXCL9 production; (4) FP promoted the expression of VDR.

\subsection{The influence of $C$. pneumoniae in steroid-resistant and steroid-sensitive patients with asthma}

Asthma is a heterogeneous, reversible, obstructive lung disease with systemic immunological features and variable phenotypes. In this study, we examined cytokine responses in asthmatic patents with different asthmatic phenotypes in relation to their steroid responsiveness and $C$. pneumoniae serological status. We aimed to determine whether steroidresistant asthmatics and steroid-sensitive patients differ only in treatment responsiveness and clinical features, or in the cytokine response to the presence of specific antigens as well. Therefore, we investigated the in vitro IL-10 and TNF- $\alpha$ responses of $C$. pneumoniae seropositive and seronegative steroid-resistant and steroid-sensitive asthmatic patients' PBMCs to a polyclonal mitogen and $C$. pneumoniae antigen. Moreover, we examined MMP-9 blood serum levels in association with their $C$. pneumoniae serostatus to detect differences between steroid-resistant and -sensitive asthmatics.

We hypothesized that a prior $C$. pneumoniae infection has an impact on IL-10 production in asthmatic patients. We examined cytokine production under different stimuli in steroidresistant and steroid-sensitive patients. Untreated PBMCs from C. pneumoniae seropositive patients secreted a higher level of IL-10 than did those from controls. These data correspond to the fact that higher serum IL-10 levels were observed in asthmatics than in controls [120]. Our results indicated that increased IL-10 responses are derived from PBMCs, indicating that in asthma pathogenesis, systemic immune responses can alter disease severity and clinical features.

In the C. pneumoniae seropositive groups, we detected greater spontaneous IL-10 secretion in steroid-resistant individuals than in steroid-sensitive individuals. Additionally, PBMCs from steroid-resistant $C$. pneumoniae seropositive asthmatics produced significantly 
higher IL-10 responses when untreated and under $C$. pneumoniae stimulation, supporting the notion that earlier $C$. pneumoniae infection contributes to an altered IL-10 response in steroidresistant asthmatics. In contrast, we did not observe a similar tendency in steroid-sensitive patients, reflecting the distinct immunological features in steroid-resistant participants.

In asthmatics, there is a positive correlation between disease severity and the IL-10 level. Accordingly, patients with asthma exhibit a higher IL-10 serum level than that of healthy individuals [121]. Glucocorticoids enhance IL-10 secretion and regulatory $\mathrm{T}$ cell functions, consequently, in steroid-resistant asthmatics, these effects cannot be observed clearly. However, it is well-known that IL-10 responses can be reversed and steroid responsiveness can be repaired in steroid-resistant asthmatics [122]. The precise role of IL-10 is unclear in asthma pathogenesis, particularly, in steroid-resistant asthmatics, and appears to be pleiotropic. One study revealed that under dexamethasone stimulation, CD4+ T cells from patients with steroidresistant asthma failed to induce IL-10 synthesis [123]. To the best of our knowledge, IL-10 production by PBMCs from asthmatic patients under different stimuli have not been studied in relation to the $C$. pneumoniae serostatus and steroid responsiveness. Collectively, our data indicate that a previous $C$. pneumoniae infection can affect IL-10 secretion by PBMCs in asthmatics and raise further demand to analyse immune response differences between steroidsensitive and -resistant patients.

Related to the TNF- $\alpha$ response, in this study, we found only one significant difference in C. pneumoniae seropositive asthmatics. PBMCs from steroid-resistant patients spontaneously secreted significantly higher levels of TNF- $\alpha$ than did those of steroid-sensitive patients, however, under $C$. pneumoniae stimulation no significant differences were detected between healthy volunteers, steroid-sensitive, and steroid resistant asthmatics. In contrast, pediatric patients with asthma have demonstrated a possibly altered ineffective Th1 immune response, resulting in lower TNF- $\alpha$ responses from C. pneumoniae infected PBMCs [56]. Differences among adult asthmatics have also been demonstrated under specific circumstances such as pregnancy [124]. These findings point out the possibility of impaired cytokine responses under determined factors that can interfere with asthma pathogenesis and C. pneumoniae infection [125]. 
Undoubtedly, former studies have revealed that TNF- $\alpha$ plays a central role in the pathogenesis of refractory asthma, particularly, in the remodelling process and steroid responsiveness. A higher TNF- $\alpha$ level was observed in BAL fluid and in the peripheral blood in asthmatics as compared with healthy controls [126]. The TNF- $\alpha$ axis contributes to activation of NF- $\mathrm{BB}$, and therefore promotes pro-inflammatory cytokine expression. TNF- $\alpha$ induces the recruitment of eosinophil and neutrophil cells and plays a role in airway remodelling and decreased glucocorticoid response via cellular and immune responses [85],[127]. $C$. pneumoniae is also involved in refractory asthma, as it alters the apoptosis process of infected cells and prolongs cell survival leading to airway structure changes. Cho et al. demonstrated that $C$. pneumoniae-infected PBMCs promoted cell proliferation in a Th2 microenvironment and $\mathrm{T}$ lymphocytes were resistant to the pro-apoptotic effect of glucocorticoids. These results were attributable to TNF- $\alpha$ axis activation and its modified function [57].

It is well-known that MMPs are involved in extracellular matrix changes and cytokine regulation. Moreover, MMP-9 levels correlate with lung function parameters, for example, FEV1 [128]. It is worth noting that pivotal differences in exhaled MMP-9 levels were detected in mild/moderate eosinophilic, severe eosinophilic, and severe neutrophilic asthmatics, indicating an association between asthma severity and airway remodelling [92].

The effect of corticosteroids on MMP-9 production is controversial. Inhaled steroids did not reduce the exhaled MMP-9 rate [91], and this trend was also observed in BAL fluids of steroid responder and non-responder patients with asthma [129]. A previous study revealed no difference between $C$. pneumoniae infected and uninfected PBMCs regarding MMP-9 production. However, C. pneumoniae infection increased TIMP-1 secretion, leading to a decreased MMP-9/TIMP-1 ratio. Moreover, dexamethasone treatment resulted in a further reduction of this ratio [90]. In this study, we measured the serum MMP-9 levels to define differences related to the $C$. pneumoniae-specific IgG serostatus and steroid responsiveness. Steroid-resistant $C$. pneumoniae seropositive patients had a lower MMP-9 level than did seronegative patients. In addition, C. pneumoniae seronegative steroid-resistant patients had significantly higher MMP-9 levels than did steroid-sensitive individuals, indicating the probable intensified remodelling process. Former studies have revealed a strong association between MMP-9 expression and C. pneumoniae infection in atherosclerotic plaques; moreover, Paolillo et al. observed increased MMP-9 production in C. pneumoniae-infected human 
endothelial cells $[130,131]$. In addition, it is well-known that MMP-9 plays a detrimental role in the pathogenesis of allergic airway diseases [132,133]. Nevertheless, the punctual effect of C. pneumoniae on MMP-9 production in bronchial epithelial cells and alveolar macrophages remains unclear and further studies are needed to define the role of $C$. pneumoniae in MMP-9 secretion and lung fibrosis.

Taken together, our findings revealed unknown features of asthmatic patients and strengthened the line of evidence that former infection could affect asthma mechanisms. To the best of our knowledge, this is the first study that compared asthmatic patients on the basis of steroid responsiveness and $C$. pneumoniae seropositivity.

In summary, we emphasize the following milestone results: (1) In steroid-sensitive $C$. pneumoniae positive patients a significant IL-10 production was observed as compared with control individuals; (2) similar differences were found in spontaneous IL-10 secretion of PBMCs from seropositive steroid-resistant asthmatics; (3) like resistant asthmatics, we found a significantly higher IL-10 production without treatment and under $C$. pneumoniae stimuli in seropositive patients as compared with seronegative individuals; (4) additionally, this study raised that seropositive steroid-resistant asthmatics expressed a significantly higher level of spontaneous TNF- $\alpha$ than steroid-sensitive asthmatics; (5) significantly higher MMP-9 levels were found in steroid-resistant seronegative patients than seropositive patients; and (6) the same trend was also seen as compared with seronegative steroid-sensitive participants. 


\section{Conclusions}

Our results demonstrate that FP treatment can lead to favourable outcomes in $C$. pneumoniae infection by enhancing IFN- $\gamma$ responses, and inducing potential anti-chlamydial cytokine and chemokine production. Our observations revealed that the effects of FP were different from other ICSs; therefore, we hypothesised that FP is beneficial in C. pneumoniae infections. Recently, patients with asthma are controlled in new ways via telemedicine and experienced fewer outpatient visits due to the COVID-19 pandemic. Therefore, investigating the associations of ICSs use and respiratory infections is especially important in order to avoid further asthma exacerbations. Our study can contribute to a better management of asthma and C. pneumoniae infections, and could assist therapeutic choices.

Additionally, we investigated the secretion of different cytokines by PBMCs from steroid-resistant and -sensitive asthmatic patients with or without stimulation. Our findings suggest that steroid resistance is associated with an altered cytokine production pattern related to $C$. pneumoniae serostatus. Our investigations confirm the heterogeneous nature of asthma disease and contribute to a better definition of the characteristics of steroid-resistant asthma at the cytokine level. Currently, there is an increasing demand to use immunotherapy in asthma management based on the inhibition of Th2 cytokines or $\operatorname{IgE}$ production [134,135]. Consequently, there is an emerging need to determine the immunological phenotypes of asthma, and thus to understand the pitfalls of conventional therapies. As our research was not without limitations, further studies are required to define the precise mechanisms underlying infectionmediated asthma and the long-term effects of persistent $C$. pneumoniae infection. 


\section{Summary}

C. pneumoniae is a ubiquitous intracellular bacterium and is implicated in the pathogenesis of obstructive lung diseases, especially playing a decisive and detrimental role in asthma. In recent years, the management and treatment of asthma have undergone a significant change as novel biological therapeutic options have arisen, targeting directly cytokines and eosinophil cells. However, based on actual asthma guidelines, the first-step treatment of asthma is switched to ICSs and their combinations. Patients are educated about the proper use of their ICSs and perform their own self-management at home. However, ICSs could show both detrimental and beneficial effects related to respiratory infections. The associations between ICS use and pneumonia have been intensively investigated, but data are still controversial as the ICSs showed distinct immunomodulatory effects with regard to cell functions, cytokine and chemokine production, and to the expression of host defence genes with antimicrobial activity.

We investigated whether FP or BUD can inhibit $C$. pneumoniae growth in vitro and found that FP suppressed the $C$. pneumoniae replication, in contrast to BUD. Based on these observations, we aimed to test this effect in vivo, in a mouse model, and investigate further underlying mechanisms at gene expression and protein levels. We detected significantly increased gene expression levels in the case of IFN- $\gamma$, IDO2, and VDR that could contribute to a potential antimicrobial defence. Besides the above, we found that in $C$. pneumoniae-infected and FP-treated mice the production of IFN- $\gamma$ and an IFN- $\gamma$ inducible chemokine, MIG/CXCL9, as well as the production of IL-10 and IL-17 were significantly increased at the protein level. All factors were previously described to reflect anti-chlamydial effects. Indeed, the number of viable $C$. pneumoniae cultured from FP-treated mice lungs was significantly lower compared to BUD-treated or control mice, suggesting the validity of our hypothesis.

Next, we intended to define distinct immunological features of steroid-resistant and sensitive asthmatic patients based on cytokine production and C. pneumoniae serostatus. We observed that steroid-resistant and -sensitive patients showed different patterns of IL-10 and TNF- $\alpha$ cytokine production, based on whether PBMCs were obtained from C. pneumoniae seropositive or seronegative patients. The differences were also manifested in baseline cytokine or MMP-9 levels. This study highlights that steroid-resistant and steroid-sensitive patients 
differ with respect to cytokine production of their PBMCs, reflecting distinct immunophenotypes of patients with asthma.

Collectively, our reported data in both studies inspire several exciting concepts in terms of $C$. pneumoniae infection, asthma treatment and their associations with patients' individual responsiveness to infections or conventional therapies. Therefore, we believe our results could contribute to further translational asthma research and therapeutic choices as well.

\section{Considered novel findings}

Both of our studies produced several novel findings related to the complex nature of $C$. pneumoniae infection in patients with asthma and the influence of asthma treatment on $C$. pneumoniae.

The following results are regarded to be state-of-the-art in Chlamydia and asthma research:

- $\quad$ FP suppressed C. pneumoniae growth in vitro and in vivo;

- FP promoted IFN- $\gamma$ expression and production, along with IDO gene expression and IFN- $\gamma$ inducible MIG/CXCL-9 secretion at the protein level in C. pneumoniae-infected mouse lungs;

- FP triggered the production of IL-17A, thus contributing to the indirect inhibition of $C$. pneumoniae replication in mice;

- Interestingly, FP induced the expression of VDR in vivo that could exert additional immunomodulatory effects;

- FP was demonstrated to affect immune responses in a distinct manner, compared to BUD;

- PBMCs of the patients with steroid-resistant or -sensitive asthma act differently in response to stimulation with $C$. pneumoniae or a polyclonal mitogen stimulation, demonstrating altered IL10 and TNF- $\alpha$ responses, based on the host's C. pneumoniae serological status. 


\section{8. Összefoglalás}

A C. pneumoniae egy széles körben elterjedt intracelluláris baktérium, mely szerepet játszik az obstruktív tüdőbetegségek patogenezisében, főként az asztma kialakulásával és exacerbációjával hozták összefüggésbe. Az elmúlt években az asztma kezelése jelentős mértékben megváltozott, a citokin és eosinophil sejtek elleni biológiai terápiák alkalmazásával. A hatályos asztmára vonatkozó nemzetközi és hazai irányelvek alapján az asztma kezelése első lépésben az inhalált kortikoszteroidokra (ICS) és azok kombinációira korlátozódik. Bár a betegek az előírt ICS terápiájukat otthonukban önállóan használják, mégis ezen inhalációs gyógyszerek alkalmazására kiemelt figyelmet érdemes fordítani, hiszen elönyös vagy akár káros hatásuk a különböző légúti fertőzésekre mai napig nem nyert egyértelmű bizonyítást. Az ICS-k használata és a tüdőgyulladás közötti összefüggéseket intenzíven vizsgálták, de az adatok továbbra is ellentmondásosak, mivel az ICS-ek különböző immunmoduláló hatásokkal bírnak, a cellularis immunitás, a citokin és kemokin termelés, valamint az antimikrobiális védekezésben szerepet játszó gének expressziója tekintetében.

Kísérleteink során megvizsgáltuk, vajon a FP és a BUD befolyásolja-e a $C$. pneumoniae növekedését in vitro, és azt találtuk, hogy a FP gátolta a $C$. pneumoniae szaporodását, ellentétben a BUD-dal. Ezt az eredményt alapul véve, a továbbiakban kísérletünket egérmodellben folytattuk, annak kiderítésére, vajon a FP és BUD hatása között tapasztalt különbség a $C$. pneumoniae szaporodását illetően in vivo is kimutatható-e. A fertőzött, FP-tal kezelt egerek tüdejéből a visszatenyészthető $C$. pneumoniae mennyisége szignifikánsan alacsonyabb volt, mint a BUD-dal kezelt vagy kontroll egerek esetében. További célunk volt, hogy feltárjuk ennek a hatásnak hátterében lévő lehetséges anti-chlamydiális immun mechanizmusokat génexpresszió és fehérje szinten is. Kísérleteink során szignifikánsan magasabb IFN- $\gamma$, IDO2 és VDR génexpressziót észleltünk, ami potenciálisan hozzájárulhat az antimikrobiális védekezéshez. Emellett a $C$. pneumoniae-val fertőzött és FP-vel kezelt egerekben az IFN- $\gamma$ és az IFN- $\gamma$ által indukálható kemokin, a MIG/CXCL-9, illetve az IL-10 és az IL-17 fokozott termelődést mutatott.

Ezt követően, a szteroid-rezisztens és -érzékeny asztmás betegek immunológiai jellemzőit tanulmányoztuk a $C$. pneumoniae szerostátusszal összefüggésben. A szteroidrezisztens és -érzékeny betegekből nyert perifériás mononukláris sejtek (PBMC) eltérő IL-10 
és TNF- $\alpha$ termelést mutattak, a különbség attól függött, hogy az asztmás betegek $C$. pneumoniae szeropozitívak vagy szeronegatívak voltak-e. A betegek szérumában mért MMP9 szintekben is szignifikáns eltérések mutatkoztak. Eredményeink alapján a szteroid-rezisztens és szteroid-érzékeny betegekből nyert PBMC-k eltérő citokin termelést mutattak, mely arra enged következtetni, hogy az asztmás betegek között különböző immunfenotípusok különíthetőek el.

Összességében, mindkét vizsgálat során nyert adataink számos új eredményt hordoztak a $C$. pneumoniae fertőzés és az asztma kezelése, illetve a szteroid terápiára rezisztens és érzékeny betegek citokin termelésére vonatkozóan, így eredményeink hozzájárulhatnak a további transzlációs asztma kutatáshoz és klinikai terápiás döntésekhez is. 


\section{Acknowledgements}

I would like to express my sincere gratitude to my supervisor, Katalin Burián, who has encouraged me since we first met at the microbiology practices and shared her thorough knowledge with me to inspire my research and even clinical work. My thesis would not have been possible without her unwavering support and belief in me.

I would like to offer my special thanks to our assistants Müllerné Deák Györgyi and Vigyikánné Váradi Anikó, for their excellent technical support.

I am deeply grateful to my colleagues at the Hospital of Chest Diseases for their patience and for substituting for me when I was unable to conduct my clinical work.

I express my thanks to my friend and colleague, Anita Sejben, for her contribution to my research work and support in my everyday problems.

I wish to thank for my very best friend, Fabiola Marinkov, for her unbroken support when I was unbearable in my worst days.

I would like to extend my sincere thanks to Zsuzsanna Csoma for leading me in the ERS SHARP, encouraging me to work on asthma research and patients with asthma. As the leader of the Hungarian Respiratory Foundation, she trusted that my work would be successful and granted the financial support to me as a PhD scholarship.

My PhD thesis is dedicated to my patients, to those who live and to those who are no longer with us. They highlighted the real value of my life and showed what honest humanity is. I will never forget them. 


\section{References}

1. Kuo, C.C.; Jackson, L.A.; Campbell, L.A.; Grayston, J.T. Chlamydia Pneumoniae (TWAR). Clin Microbiol Rev 1995, 8, 451-461, doi:10.1128/CMR.8.4.451-461.1995.

2. Carr, T.F.; Kraft, M. Chronic Infection and Severe Asthma. Immunol Allergy Clin North Am 2016, 36, 483-502, doi:10.1016/j.iac.2016.03.010.

3. Burián, K.; Hegyesi, H.; Buzás, E.; Endrész, V.; Kis, Z.; Falus, A.; Gönczöl, E. Chlamydophila (Chlamydia) Pneumoniae Induces Histidine Decarboxylase Production in the Mouse Lung. Immunol. Lett. 2003, 89, 229-236.

4. Galasso, G.J.; Manire, G.P. Effect of Antiserum and Antibiotics on Persistent Infection of HeLa Cells with Meningopneumonitis Virus. J Immunol 1961, 86, 382-385.

5. Matsumoto, A.; Manire, G.P. Electron Microscopic Observations on the Effects of Penicillin on the Morphology of Chlamydia Psittaci. J Bacteriol 1970, 101, 278-285, doi:10.1128/JB.101.1.278-285.1970.

6. Kokab, A.; Jennings, R.; Eley, A.; Pacey, A.A.; Cross, N.A. Analysis of Modulated Gene Expression in a Model of Interferon-Gamma-Induced Persistence of Chlamydia Trachomatis in HEp-2 Cells. Microb Pathog 2010, 49, 217-225, doi:10.1016/j.micpath.2010.06.002.

7. Pettengill, M.A.; Lam, V.W.; Ojcius, D.M. The Danger Signal Adenosine Induces Persistence of Chlamydial Infection through Stimulation of A2b Receptors. PLoS One 2009, 4, e8299, doi:10.1371/journal.pone.0008299.

8. Wiedeman, J.A.; Kaul, R.; Heuer, L.S.; Thao, N.N.; Pinkerton, K.E.; Wenman, W.M. Tobacco Smoke Induces Persistent Infection of Chlamydophila Pneumoniae in HEp-2 Cells. Microb Pathog 2004, 37, 141-148, doi:10.1016/j.micpath.2004.06.006.

9. Deka, S.; Vanover, J.; Dessus-Babus, S.; Whittimore, J.; Howett, M.K.; Wyrick, P.B.; Schoborg, R.V. Chlamydia Trachomatis Enters a Viable but Non-Cultivable (Persistent) State within Herpes Simplex Virus Type 2 (HSV-2) Co-Infected Host Cells. Cell Microbiol 2006, 8, 149-162, doi:10.1111/j.1462-5822.2005.00608.x.

10. Schoborg, R.V. Chlamydia Persistence -- a Tool to Dissect Chlamydia--Host Interactions. Microbes Infect 2011, 13, 649-662, doi:10.1016/j.micinf.2011.03.004.

11. Vanover, J.; Kintner, J.; Whittimore, J.; Schoborg, R.V. Interaction of Herpes Simplex Virus Type 2 (HSV-2) Glycoprotein D with the Host Cell Surface Is Sufficient to Induce Chlamydia Trachomatis Persistence. Microbiology (Reading) 2010, 156, 1294-1302, doi:10.1099/mic.0.036566-0.

12. Su, H.; Caldwell, H.D. CD4+ T Cells Play a Significant Role in Adoptive Immunity to Chlamydia Trachomatis Infection of the Mouse Genital Tract. Infect Immun 1995, 63, 33023308, doi:10.1128/IAI.63.9.3302-3308.1995. 
13. Perry, L.L.; Feilzer, K.; Caldwell, H.D. Immunity to Chlamydia Trachomatis Is Mediated by T Helper 1 Cells through IFN-Gamma-Dependent and -Independent Pathways. $J$ Immunol 1997, 158, 3344-3352.

14. Loomis, W.P.; Starnbach, M.N. T Cell Responses to Chlamydia Trachomatis. Curr. Opin. Microbiol. 2002, 5, 87-91.

15. Beatty, W.L.; Belanger, T.A.; Desai, A.A.; Morrison, R.P.; Byrne, G.I. Tryptophan Depletion as a Mechanism of Gamma Interferon-Mediated Chlamydial Persistence. Infect Immun 1994, 62, 3705-3711, doi:10.1128/IAI.62.9.3705-3711.1994.

16. Sueltenfuss, E.A.; Pollard, M. Cytochemical Assay of Interferon Produced by Duck Hepatitis Virus. Science 1963, 139, 595-596, doi:10.1126/science.139.3555.595.

17. Byrne, G.I.; Lehmann, L.K.; Landry, G.J. Induction of Tryptophan Catabolism Is the Mechanism for Gamma-Interferon-Mediated Inhibition of Intracellular Chlamydia Psittaci Replication in T24 Cells. Infect. Immun. 1986, 53, 347-351.

18. Carlin, J.M.; Borden, E.C.; Byrne, G.I. Interferon-Induced Indoleamine 2,3Dioxygenase Activity Inhibits Chlamydia Psittaci Replication in Human Macrophages. $J$ Interferon Res 1989, 9, 329-337, doi:10.1089/jir.1989.9.329.

19. Rapoza, P.A.; Tahija, S.G.; Carlin, J.P.; Miller, S.L.; Padilla, M.L.; Byrne, G.I. Effect of Interferon on a Primary Conjunctival Epithelial Cell Model of Trachoma. Invest Ophthalmol Vis Sci 1991, 32, 2919-2923.

20. Pantoja, L.G.; Miller, R.D.; Ramirez, J.A.; Molestina, R.E.; Summersgill, J.T. Characterization of Chlamydia Pneumoniae Persistence in HEp-2 Cells Treated with Gamma Interferon. Infect Immun 2001, 69, 7927-7932, doi:10.1128/IAI.69.12.7927-7932.2001.

21. Burian, K.; Endresz, V.; Deak, J.; Kormanyos, Z.; Pal, A.; Nelson, D.; Virok, D.P. Transcriptome Analysis Indicates an Enhanced Activation of Adaptive and Innate Immunity by Chlamydia-Infected Murine Epithelial Cells Treated with Interferon $\gamma$. J. Infect. Dis. 2010, 202, 1405-1414, doi:10.1086/656526.

22. Balogh, E.P.; Faludi, I.; Virók, D.P.; Endrész, V.; Burián, K. Chlamydophila Pneumoniae Induces Production of the Defensin-like MIG/CXCL9, Which Has in Vitro Antichlamydial Activity. Int. J. Med. Microbiol. 2011, 301, 252-259, doi:10.1016/j.ijmm.2010.08.020.

23. Bernstein-Hanley, I.; Coers, J.; Balsara, Z.R.; Taylor, G.A.; Starnbach, M.N.; Dietrich, W.F. The P47 GTPases Igtp and Irgb10 Map to the Chlamydia Trachomatis Susceptibility Locus Ctrq-3 and Mediate Cellular Resistance in Mice. Proc Natl Acad Sci U S A 2006, 103, 14092-14097, doi:10.1073/pnas.0603338103.

24. Tietzel, I.; El-Haibi, C.; Carabeo, R.A. Human Guanylate Binding Proteins Potentiate the Anti-Chlamydia Effects of Interferon-Gamma. PLoS One 2009, 4, e6499, doi:10.1371/journal.pone.0006499. 
25. Panzetta, M.E.; Valdivia, R.H.; Saka, H.A. Chlamydia Persistence: A Survival Strategy to Evade Antimicrobial Effects in-Vitro and in-Vivo. Front Microbiol 2018, 9, 3101, doi:10.3389/fmicb.2018.03101.

26. Schmidt, S.V.; Schultze, J.L. New Insights into IDO Biology in Bacterial and Viral Infections. Front Immunol 2014, 5, 384, doi:10.3389/fimmu.2014.00384.

27. Kocher, F.; Amann, A.; Zimmer, K.; Geisler, S.; Fuchs, D.; Pichler, R.; Wolf, D.; Kurz, K.; Seeber, A.; Pircher, A. High Indoleamine-2,3-Dioxygenase 1 (IDO) Activity Is Linked to Primary Resistance to Immunotherapy in Non-Small Cell Lung Cancer (NSCLC). Transl Lung Cancer Res 2021, 10, 304-313, doi:10.21037/tlcr-20-380.

28. Shi, Y.; Yin, J.; Zhan, H.; Feng, G.; Zhang, X.; Su, X.; Song, Y.; Xia, X.; Zhou, X.; Shen, P. The Pathogenesis of Chlamydia Pneumoniae-Type Pneumonitis in Mice. Chin Med J (Engl) 2003, 116, 328-332.

29. Aggarwal, S.; Ghilardi, N.; Xie, M.-H.; de Sauvage, F.J.; Gurney, A.L. Interleukin-23 Promotes a Distinct CD4 T Cell Activation State Characterized by the Production of Interleukin-17. J Biol Chem 2003, 278, 1910-1914, doi:10.1074/jbc.M207577200.

30. Zhou, X.; Chen, Q.; Moore, J.; Kolls, J.K.; Halperin, S.; Wang, J. Critical Role of the Interleukin-17/Interleukin-17 Receptor Axis in Regulating Host Susceptibility to Respiratory Infection with Chlamydia Species. Infect Immun 2009, 77, 5059-5070, doi:10.1128/IAI.0040309.

31. Mosolygó, T.; Korcsik, J.; Balogh, E.P.; Faludi, I.; Virók, D.P.; Endrész, V.; Burián, K. Chlamydophila Pneumoniae Re-Infection Triggers the Production of IL-17A and IL-17E, Important Regulators of Airway Inflammation. Inflamm Res 2013, 62, 451-460, doi:10.1007/s00011-013-0596-1.

32. Smith, D.H.; Malone, D.C.; Lawson, K.A.; Okamoto, L.J.; Battista, C.; Saunders, W.B. A National Estimate of the Economic Costs of Asthma. Am J Respir Crit Care Med 1997, 156, 787-793, doi:10.1164/ajrccm.156.3.9611072.

33. Demoly, P.; Gueron, B.; Annunziata, K.; Adamek, L.; Walters, R.D. Update on Asthma Control in Five European Countries: Results of a 2008 Survey. Eur Respir Rev 2010, 19, 150 157, doi:10.1183/09059180.00002110.

34. Hahn, D.L.; McDonald, R. Can Acute Chlamydia Pneumoniae Respiratory Tract Infection Initiate Chronic Asthma? Ann Allergy Asthma Immunol 1998, 81, 339-344, doi:10.1016/S1081-1206(10)63126-2.

35. Hahn, D.L.; Dodge, R.W.; Golubjatnikov, R. Association of Chlamydia Pneumoniae (Strain TWAR) Infection with Wheezing, Asthmatic Bronchitis, and Adult-Onset Asthma. JAMA 1991, 266, 225-230.

36. Johnston, S.L.; Blasi, F.; Black, P.N.; Martin, R.J.; Farrell, D.J.; Nieman, R.B.; TELICAST Investigators The Effect of Telithromycin in Acute Exacerbations of Asthma. $N$ Engl J Med 2006, 354, 1589-1600, doi:10.1056/NEJMoa044080. 
37. Johnston, S.L.; Szigeti, M.; Cross, M.; Brightling, C.; Chaudhuri, R.; Harrison, T.; Mansur, A.; Robison, L.; Sattar, Z.; Jackson, D.; et al. Azithromycin for Acute Exacerbations of Asthma: The AZALEA Randomized Clinical Trial. JAMA Intern Med 2016, 176, 16301637, doi:10.1001/jamainternmed.2016.5664.

38. von, H.L.C. Role of Persistent Infection in the Control and Severity of Asthma: Focus on Chlamydia Pneumoniae. Eur Respir J 2002, 19, 546-556, doi:10.1183/09031936.02.00254402.

39. Hahn, D.L.; Schure, A.; Patel, K.; Childs, T.; Drizik, E.; Webley, W. Chlamydia Pneumoniae-Specific IgE Is Prevalent in Asthma and Is Associated with Disease Severity. PLoS One 2012, 7, e35945, doi:10.1371/journal.pone.0035945.

40. Cook, P.J.; Davies, P.; Tunnicliffe, W.; Ayres, J.G.; Honeybourne, D.; Wise, R. Chlamydia Pneumoniae and Asthma. Thorax 1998, 53, 254-259, doi:10.1136/thx.53.4.254.

41. Webley, W.C.; Hahn, D.L. Infection-Mediated Asthma: Etiology, Mechanisms and Treatment Options, with Focus on Chlamydia Pneumoniae and Macrolides. Respir Res 2017, 18, doi:10.1186/s12931-017-0584-z.

42. Shemer-Avni, Y.; Lieberman, D. Chlamydia Pneumoniae-Induced Ciliostasis in Ciliated Bronchial Epithelial Cells. J Infect Dis 1995, 171, 1274-1278, doi:10.1093/infdis/171.5.1274.

43. Horvat, J.C.; Starkey, M.R.; Kim, R.Y.; Phipps, S.; Gibson, P.G.; Beagley, K.W.; Foster, P.S.; Hansbro, P.M. Early-Life Chlamydial Lung Infection Enhances Allergic Airways Disease through Age-Dependent Differences in Immunopathology. J. Allergy Clin. Immunol. 2010, 125, 617-625, 625.e1-625.e6, doi:10.1016/j.jaci.2009.10.018.

44. Patel, K.K.; Webley, W.C. Evidence of Infectious Asthma Phenotype: ChlamydiaInduced Allergy and Pathogen-Specific IgE in a Neonatal Mouse Model. PLoS One 2013, 8, e83453, doi:10.1371/journal.pone.0083453.

45. Johnston, S.L.; Martin, R.J. Chlamydophila Pneumoniae and Mycoplasma Pneumoniae: A Role in Asthma Pathogenesis? Am J Respir Crit Care Med 2005, 172, 1078-1089, doi:10.1164/rccm.200412-1743PP.

46. Gencay, M.; Rüdiger, J.J.; Tamm, M.; Solér, M.; Perruchoud, A.P.; Roth, M. Increased Frequency of Chlamydia Pneumoniae Antibodies in Patients with Asthma. Am. J. Respir. Crit. Care Med. 2001, 163, 1097-1100, doi:10.1164/ajrccm.163.5.2003162.

47. Huittinen, T.; Hahn, D.; Anttila, T.; Wahlström, E.; Saikku, P.; Leinonen, M. Host Immune Response to Chlamydia Pneumoniae Heat Shock Protein 60 Is Associated with Asthma. Eur Respir J 2001, 17, 1078-1082, doi:10.1183/09031936.01.00089001.

48. Falck, G.; Gnarpe, J.; Hansson, L.-O.; Svärdsudd, K.; Gnarpe, H. Comparison of Individuals with and without Specific IgA Antibodies to Chlamydia Pneumoniae: Respiratory Morbidity and the Metabolic Syndrome. Chest 2002, 122, 1587-1593, doi:10.1378/chest.122.5.1587. 
49. Von, H.L.; Vasankari, T.; Liippo, K.; Wahlström, E.; Puolakkainen, M. Chlamydia Pneumoniae and Severity of Asthma. Scand $J$ Infect Dis 2002, 34, 22-27, doi:10.1080/00365540110077155.

50. Black, P.N.; Scicchitano, R.; Jenkins, C.R.; Blasi, F.; Allegra, L.; Wlodarczyk, J.; Cooper, B.C. Serological Evidence of Infection with Chlamydia Pneumoniae Is Related to the Severity of Asthma. Eur. Respir. J. 2000, 15, 254-259.

51. ten Brinke, A.; van Dissel, J.T.; Sterk, P.J.; Zwinderman, A.H.; Rabe, K.F.; Bel, E.H. Persistent Airflow Limitation in Adult-Onset Nonatopic Asthma Is Associated with Serologic Evidence of Chlamydia Pneumoniae Infection. J. Allergy Clin. Immunol. 2001, 107, 449-454, doi:10.1067/mai.2001.113047.

52. Kaukoranta-Tolvanen, S.S.; Teppo, A.M.; Laitinen, K.; Saikku, P.; Linnavuori, K.; Leinonen, M. Growth of Chlamydia Pneumoniae in Cultured Human Peripheral Blood Mononuclear Cells and Induction of a Cytokine Response. Microb Pathog 1996, 21, 215-221, doi:10.1006/mpat.1996.0056.

53. Redecke, V.; Dalhoff, K.; Bohnet, S.; Braun, J.; Maass, M. Interaction of Chlamydia Pneumoniae and Human Alveolar Macrophages: Infection and Inflammatory Response. Am J Respir Cell Mol Biol 1998, 19, 721-727, doi:10.1165/ajrcmb.19.5.3072.

54. Yang, J.; Hooper, W.C.; Phillips, D.J.; Tondella, M.L.; Talkington, D.F. Induction of Proinflammatory Cytokines in Human Lung Epithelial Cells during Chlamydia Pneumoniae Infection. Infect Immun 2003, 71, 614-620, doi:10.1128/iai.71.2.614-620.2003.

55. Smith-Norowitz, T.A.; Chotikanatis, K.; Erstein, D.P.; Perlman, J.; Norowitz, Y.M.; Joks, R.; Durkin, H.G.; Hammerschlag, M.R.; Kohlhoff, S. Chlamydia Pneumoniae Enhances the Th2 Profile of Stimulated Peripheral Blood Mononuclear Cells from Asthmatic Patients. Human Immunology 2016, 77, 382-388, doi:10.1016/j.humimm.2016.02.010.

56. Smith-Norowitz, T.A.; Chotikanatis, K.; Weaver, D.; Ditkowsky, J.; Norowitz, Y.M.; Hammerschlag, M.R.; Joks, R.; Kohlhoff, S. Chlamydia Pneumoniae-Induced Tumour Necrosis Factor Alpha Responses Are Lower in Children with Asthma Compared with NonAsthma. BMJ Open Respir Res 2018, 5, e000239, doi:10.1136/bmjresp-2017-000239.

57. Cho, Y.S.; Kim, T.-B.; Lee, T.-H.; Moon, K.-A.; Lee, J.; Kim, Y.-K.; Lee, K.-Y.; Moon, H.-B. Chlamydia Pneumoniae Infection Enhances Cellular Proliferation and Reduces Steroid Responsiveness of Human Peripheral Blood Mononuclear Cells via a Tumor Necrosis FactorAlpha-Dependent Pathway. Clin. Exp. Allergy 2005, 35, 1625-1631, doi:10.1111/j.13652222.2005.02391.x.

58. Smith-Norowitz, T.A.; Weaver, D.; Chorny, V.; Norowitz, Y.M.; Lent, D.; Hammerschlag, M.R.; Joks, R.; Kohlhoff, S. Chlamydia Pneumoniae Induces Interferon Gamma Responses in Peripheral Blood Mononuclear Cells in Children with Allergic Asthma. Scand. J. Immunol. 2017, 86, 59-64, doi:10.1111/sji.12561. 
59. Morjaria, J.B.; Rigby, A.; Morice, A.H. Inhaled Corticosteroid Use and the Risk of Pneumonia and COPD Exacerbations in the UPLIFT Study. Lung 2017, 195, 281-288, doi:10.1007/s00408-017-9990-8.

60. Sin, D.D.; Tashkin, D.; Zhang, X.; Radner, F.; Sjöbring, U.; Thorén, A.; Calverley, P.M.A.; Rennard, S.I. Budesonide and the Risk of Pneumonia: A Meta-Analysis of Individual Patient Data. Lancet 2009, 374, 712-719, doi:10.1016/S0140-6736(09)61250-2.

61. McKeever, T.; Harrison, T.W.; Hubbard, R.; Shaw, D. Inhaled Corticosteroids and the Risk of Pneumonia in People with Asthma: A Case-Control Study. Chest 2013, 144, 17881794, doi:10.1378/chest.13-0871.

62. Janson, C.; Stratelis, G.; Miller-Larsson, A.; Harrison, T.W.; Larsson, K. Scientific Rationale for the Possible Inhaled Corticosteroid Intraclass Difference in the Risk of Pneumonia in COPD. Int $J$ Chron Obstruct Pulmon Dis 2017, 12, 3055-3064, doi:10.2147/COPD.S143656.

63. Belchamber, K.B.; Thomas, C.M.; Dunne, A.E.; Barnes, P.J.; Donnelly, L.E. Comparison of Fluticasone Propionate and Budesonide on COPD Macrophage and Neutrophil Function. Int $J$ Chron Obstruct Pulmon Dis 2018, 13, 2883-2897, doi:10.2147/COPD.S169337.

64. Yamaya, M.; Nishimura, H.; Nadine, L.; Kubo, H.; Nagatomi, R. Formoterol and Budesonide Inhibit Rhinovirus Infection and Cytokine Production in Primary Cultures of Human Tracheal Epithelial Cells. Respir Investig 2014, 52, 251-260, doi:10.1016/j.resinv.2014.03.004.

65. Bochkov, Y.A.; Busse, W.W.; Brockman-Schneider, R.A.; Evans, M.D.; Jarjour, N.N.; McCrae, C.; Miller-Larsson, A.; Gern, J.E. Budesonide and Formoterol Effects on Rhinovirus Replication and Epithelial Cell Cytokine Responses. Respir. Res. 2013, 14, 98, doi:10.1186/1465-9921-14-98.

66. van den Berge, M.; Jonker, M.R.; Miller-Larsson, A.; Postma, D.S.; Heijink, I.H. Effects of Fluticasone Propionate and Budesonide on the Expression of Immune Defense Genes in Bronchial Epithelial Cells. Pulm Pharmacol Ther 2018, 50, 47-56, doi:10.1016/j.pupt.2018.04.002.

67. Yamaya, M.; Nishimura, H.; Deng, X.; Sugawara, M.; Watanabe, O.; Nomura, K.; Shimotai, Y.; Momma, H.; Ichinose, M.; Kawase, T. Inhibitory Effects of Glycopyrronium, Formoterol, and Budesonide on Coronavirus HCoV-229E Replication and Cytokine Production by Primary Cultures of Human Nasal and Tracheal Epithelial Cells. Respir Investig 2020, 58, 155-168, doi:10.1016/j.resinv.2019.12.005.

68. Jaffuel, D.; Demoly, P.; Gougat, C.; Balaguer, P.; Mautino, G.; Godard, P.; Bousquet, J.; Mathieu, M. Transcriptional Potencies of Inhaled Glucocorticoids. Am J Respir Crit Care Med 2000, 162, 57-63, doi:10.1164/ajrccm.162.1.9901006. 
69. Ek, A.; Larsson, K.; Siljerud, S.; Palmberg, L. Fluticasone and Budesonide Inhibit Cytokine Release in Human Lung Epithelial Cells and Alveolar Macrophages. Allergy 1999, 54, 691-699, doi:10.1034/j.1398-9995.1999.00087.x.

70. Edsbäcker, S.; Wollmer, P.; Selroos, O.; Borgström, L.; Olsson, B.; Ingelf, J. Do Airway Clearance Mechanisms Influence the Local and Systemic Effects of Inhaled Corticosteroids? Pulm Pharmacol Ther 2008, 21, 247-258, doi:10.1016/j.pupt.2007.08.005.

71. Miller-Larsson, A.; Mattsson, H.; Hjertberg, E.; Dahlbäck, M.; Tunek, A.; Brattsand, R. Reversible Fatty Acid Conjugation of Budesonide. Novel Mechanism for Prolonged Retention of Topically Applied Steroid in Airway Tissue. Drug Metab. Dispos. 1998, 26, 623-630.

72. Wang, P.; Wang, X.; Yang, X.; Liu, Z.; Wu, M.; Li, G. Budesonide Suppresses Pulmonary Antibacterial Host Defense by Down-Regulating Cathelicidin-Related Antimicrobial Peptide in Allergic Inflammation Mice and in Lung Epithelial Cells. BMC Immunol. 2013, 14, 7, doi:10.1186/1471-2172-14-7.

73. (*NEW) 2018 GINA Report: Global Strategy for Asthma Management and Prevention | Global Initiative for Asthma - GINA Available online: http://ginasthma.org/2018-gina-reportglobal-strategy-for-asthma-management-and-prevention/ (accessed on 9 June 2018).

74. Schwartz, H.J.; Lowell, F.C.; Melby, J.C. Steroid Resistance in Bronchial Asthma. Ann. Intern. Med. 1968, 69, 493-499.

75. Kim, R.Y.; Horvat, J.C.; Pinkerton, J.W.; Starkey, M.R.; Essilfie, A.T.; Mayall, J.R.; Nair, P.M.; Hansbro, N.G.; Jones, B.; Haw, T.J.; et al. MicroRNA-21 Drives Severe, SteroidInsensitive Experimental Asthma by Amplifying Phosphoinositide 3-Kinase-Mediated Suppression of Histone Deacetylase 2. J. Allergy Clin. Immunol. 2017, 139, 519-532, doi:10.1016/j.jaci.2016.04.038.

76. Li, L.-B.; Leung, D.Y.M.; Martin, R.J.; Goleva, E. Inhibition of Histone Deacetylase 2 Expression by Elevated Glucocorticoid Receptor Beta in Steroid-Resistant Asthma. Am. J. Respir. Crit. Care Med. 2010, 182, 877-883, doi:10.1164/rccm.201001-0015OC.

77. Hansbro, P.M.; Kim, R.Y.; Starkey, M.R.; Donovan, C.; Dua, K.; Mayall, J.R.; Liu, G.; Hansbro, N.G.; Simpson, J.L.; Wood, L.G.; et al. Mechanisms and Treatments for Severe, Steroid-Resistant Allergic Airway Disease and Asthma. Immunol. Rev. 2017, 278, 41-62, doi:10.1111/imr.12543.

78. Hansbro, P.M.; Starkey, M.R.; Mattes, J.; Horvat, J.C. Pulmonary Immunity during Respiratory Infections in Early Life and the Development of Severe Asthma. Ann Am Thorac Soc 2014, 11 Suppl 5, S297-302, doi:10.1513/AnnalsATS.201402-086AW.

79. Starkey, M.R.; Nguyen, D.H.; Kim, R.Y.; Nair, P.M.; Brown, A.C.; Essifie, A.-T.; Horvat, J.C.; Hansbro, P.M. Programming of the Lung in Early Life by Bacterial Infections Predisposes to Chronic Respiratory Disease. Clin Obstet Gynecol 2013, 56, 566-576, doi:10.1097/GRF.0b013e3182993a0c. 
80. Patel, K.K.; Vicencio, A.G.; Du, Z.; Tsirilakis, K.; Salva, P.S.; Webley, W.C. Infectious Chlamydia Pneumoniae Is Associated with Elevated Interleukin-8 and Airway Neutrophilia in Children with Refractory Asthma. Pediatr. Infect. Dis. J. 2010, 29, 1093-1098.

81. Borish, L.; Aarons, A.; Rumbyrt, J.; Cvietusa, P.; Negri, J.; Wenzel, S. Interleukin-10 Regulation in Normal Subjects and Patients with Asthma. J. Allergy Clin. Immunol. 1996, 97, 1288-1296.

82. Matsumoto, K.; Inoue, H.; Fukuyama, S.; Tsuda, M.; Ikegami, T.; Kibe, A.; Yoshiura, Y.; Komori, M.; Hamasaki, N.; Aizawa, H.; et al. Decrease of Interleukin-10-Producing T Cells in the Peripheral Blood of Severe Unstable Atopic Asthmatics. Int. Arch. Allergy Immunol. 2004, 134, 295-302, doi:10.1159/000079167.

83. Kim, R.Y.; Pinkerton, J.W.; Essilfie, A.T.; Robertson, A.A.B.; Baines, K.J.; Brown, A.C.; Mayall, J.R.; Ali, M.K.; Starkey, M.R.; Hansbro, N.G.; et al. Role for NLRP3 Inflammasome-Mediated, IL-1 $\beta$-Dependent Responses in Severe, Steroid-Resistant Asthma. Am. J. Respir. Crit. Care Med. 2017, 196, 283-297, doi:10.1164/rccm.201609-18300C.

84. Rahman, M.M.; Prabhala, P.; Rumzhum, N.N.; Patel, B.S.; Wickop, T.; Hansbro, P.M.; Verrills, N.M.; Ammit, A.J. TLR2 Ligation Induces Corticosteroid Insensitivity in A549 Lung Epithelial Cells: Anti-Inflammatory Impact of PP2A Activators. Int. J. Biochem. Cell Biol. 2016, 78, 279-287, doi:10.1016/j.biocel.2016.07.030.

85. Berry, M.; Brightling, C.; Pavord, I.; Wardlaw, A. TNF-Alpha in Asthma. Curr Opin Pharmacol 2007, 7, 279-282, doi:10.1016/j.coph.2007.03.001.

86. Adcock, I.M.; Barnes, P.J. Molecular Mechanisms of Corticosteroid Resistance. Chest 2008, 134, 394-401, doi:10.1378/chest.08-0440.

87. Bossé, M.; Chakir, J.; Rouabhia, M.; Boulet, L.P.; Audette, M.; Laviolette, M. Serum Matrix Metalloproteinase-9:Tissue Inhibitor of Metalloproteinase-1 Ratio Correlates with Steroid Responsiveness in Moderate to Severe Asthma. Am. J. Respir. Crit. Care Med. 1999, 159, 596-602, doi:10.1164/ajrccm.159.2.9802045.

88. Mautino, G.; Oliver, N.; Chanez, P.; Bousquet, J.; Capony, F. Increased Release of Matrix Metalloproteinase-9 in Bronchoalveolar Lavage Fluid and by Alveolar Macrophages of Asthmatics. Am. J. Respir. Cell Mol. Biol. 1997, 17, 583-591, doi:10.1165/ajrcmb.17.5.2562.

89. Rödel, J.; Prochnau, D.; Prager, K.; Pentcheva, E.; Hartmann, M.; Straube, E. Increased Production of Matrix Metalloproteinases 1 and 3 by Smooth Muscle Cells upon Infection with Chlamydia Pneumoniae. FEMS Immunol. Med. Microbiol. 2003, 38, 159-164.

90. Park, C.-S.; Lee, Y.S.; Kwon, H.-S.; Lee, T.; Kim, T.-B.; Moon, K.-A.; Yoo, B.; Moon, H.-B.; Cho, Y.S. Chlamydophila Pneumoniae Inhibits Corticosteroid-Induced Suppression of Metalloproteinase-9 and Tissue Inhibitor Metalloproteinase-1 Secretion by Human Peripheral Blood Mononuclear Cells. J. Med. Microbiol. 2012, 61, 705-711, doi:10.1099/jmm.0.0366240 . 
91. Grzela, K.; Zagorska, W.; Krejner, A.; Litwiniuk, M.; Zawadzka-Krajewska, A.; Banaszkiewicz, A.; Kulus, M.; Grzela, T. Prolonged Treatment with Inhaled Corticosteroids Does Not Normalize High Activity of Matrix Metalloproteinase-9 in Exhaled Breath Condensates of Children with Asthma. Arch. Immunol. Ther. Exp. (Warsz.) 2015, 63, 231-237, doi:10.1007/s00005-015-0328-z.

92. Barbaro, M.P.F.; Spanevello, A.; Palladino, G.P.; Salerno, F.G.; Lacedonia, D.; Carpagnano, G.E. Exhaled Matrix Metalloproteinase-9 (MMP-9) in Different Biological Phenotypes of Asthma. Eur. J. Intern. Med. 2014, 25, 92-96, doi:10.1016/j.ejim.2013.08.705.

93. Eszik, I.; Lantos, I.; Önder, K.; Somogyvári, F.; Burián, K.; Endrész, V.; Virok, D.P. High Dynamic Range Detection of Chlamydia Trachomatis Growth by Direct Quantitative PCR of the Infected Cells. J. Microbiol. Methods 2016, 120, 15-22, doi:10.1016/j.mimet.2015.11.010.

94. Virók, D.P.; Eszik, I.; Mosolygó, T.; Önder, K.; Endrész, V.; Burián, K. A Direct Quantitative PCR-Based Measurement of Herpes Simplex Virus Susceptibility to Antiviral Drugs and Neutralizing Antibodies. $J$ Virol Methods 2017, 242, 46-52, doi:10.1016/j.jviromet.2017.01.007.

95. Zuśka-Prot, M.; Maślanka, T. Effect of Inhaled and Systemic Glucocorticoid Treatment on CD4+ Regulatory and Effector $\mathrm{T}$ Cells in a Mouse Model of Allergic Asthma. Int Immunopharmacol 2017, 45, 98-109, doi:10.1016/j.intimp.2017.02.005.

96. Becker, A.B.; Abrams, E.M. Asthma Guidelines: The Global Initiative for Asthma in Relation to National Guidelines. Curr Opin Allergy Clin Immunol 2017, 17, 99-103, doi:10.1097/ACI.0000000000000346.

97. Penttilä, J.M.; Anttila, M.; Puolakkainen, M.; Laurila, A.; Varkila, K.; Sarvas, M.; Mäkelä, P.H.; Rautonen, N. Local Immune Responses to Chlamydia Pneumoniae in the Lungs of BALB/c Mice during Primary Infection and Reinfection. Infect. Immun. 1998, 66, 51135118.

98. Virok, D.P.; Raffai, T.; Kókai, D.; Paróczai, D.; Bogdanov, A.; Veres, G.; Vécsei, L.; Poliska, S.; Tiszlavicz, L.; Somogyvári, F.; et al. Indoleamine 2,3-Dioxygenase Activity in Chlamydia Muridarum and Chlamydia Pneumoniae Infected Mouse Lung Tissues. Front Cell Infect Microbiol 2019, 9, 192, doi:10.3389/fcimb.2019.00192.

99. Marcellini, A.; Swieboda, D.; Guedán, A.; Farrow, S.N.; Casolari, P.; Contoli, M.; Johnston, S.L.; Papi, A.; Solari, R. Glucocorticoids Impair Type I IFN Signalling and Enhance Rhinovirus Replication. Eur J Pharmacol 2020, 893, 173839, doi:10.1016/j.ejphar.2020.173839.

100. Baeke, F.; Takiishi, T.; Korf, H.; Gysemans, C.; Mathieu, C. Vitamin D: Modulator of the Immune System. Curr Opin Pharmacol 2010, 10, 482-496, doi:10.1016/j.coph.2010.04.001. 
101. Nelson, D.E.; Virok, D.P.; Wood, H.; Roshick, C.; Johnson, R.M.; Whitmire, W.M.; Crane, D.D.; Steele-Mortimer, O.; Kari, L.; McClarty, G.; et al. Chlamydial IFN-Gamma Immune Evasion Is Linked to Host Infection Tropism. Proc. Natl. Acad. Sci. U.S.A. 2005, 102, 10658-10663, doi:10.1073/pnas.0504198102.

102. Yeh, J.-J.; Lin, C.-L.; Kao, C.-H. Associations among Chronic Obstructive Pulmonary Disease with Asthma, Pneumonia, and Corticosteroid Use in the General Population. PLoS ONE 2020, 15, e0229484, doi:10.1371/journal.pone.0229484.

103. Kim, M.H.; Rhee, C.K.; Shim, J.S.; Park, S.Y.; Yoo, K.H.; Kim, B.Y.; Bae, H.W.; Sim, Y.S.; Chang, J.H.; Cho, Y.J.; et al. Inhaled Corticosteroids in Asthma and the Risk of Pneumonia. Allergy Asthma Immunol Res 2019, 11, 795-805, doi:10.4168/aair.2019.11.6.795.

104. Heijink, I.H.; Jonker, M.R.; de Vries, M.; van Oosterhout, A.J.M.; Telenga, E.; Ten Hacken, N.H.T.; Postma, D.S.; van den Berge, M. Budesonide and Fluticasone Propionate Differentially Affect the Airway Epithelial Barrier. Respir. Res. 2016, 17, 2, doi:10.1186/s12931-015-0318-z.

105. Kim, S.-R.; Song, J.-H.; Ahn, J.-H.; Lee, G.-S.; Ahn, H.; Yoon, S.-I.; Kang, S.G.; Kim, P.-H.; Jeon, S.-M.; Choi, E.-J.; et al. Antiviral and Anti-Inflammatory Activity of Budesonide against Human Rhinovirus Infection Mediated via Autophagy Activation. Antiviral Res. 2018, 151, 87-96, doi:10.1016/j.antiviral.2018.01.012.

106. Leigh, R.; Mostafa, M.M.; King, E.M.; Rider, C.F.; Shah, S.; Dumonceaux, C.; Traves, S.L.; McWhae, A.; Kolisnik, T.; Kooi, C.; et al. An Inhaled Dose of Budesonide Induces Genes Involved in Transcription and Signaling in the Human Airways: Enhancement of Anti- and Proinflammatory Effector Genes. Pharmacol Res Perspect 2016, 4, e00243, doi:10.1002/prp2.243.

107. Umland, S.P.; Nahrebne, D.K.; Razac, S.; Beavis, A.; Pennline, K.J.; Egan, R.W.; Billah, M.M. The Inhibitory Effects of Topically Active Glucocorticoids on IL-4, IL-5, and Interferon-Gamma Production by Cultured Primary CD4+ T Cells. J Allergy Clin Immunol 1997, 100, 511-519, doi:10.1016/s0091-6749(97)70144-1.

108. Smith-Norowitz, T.A.; Loeffler, J.; Huang, Y.; Klein, E.; Norowitz, Y.M.; Hammerschlag, M.R.; Joks, R.; Kohlhoff, S. Chlamydia Pneumoniae Immunoglobulin E Antibody Levels in Patients with Asthma Compared with Non-Asthma. Heliyon 2020, 6, e03512, doi:10.1016/j.heliyon.2020.e03512.

109. Davies, J.M.; Carroll, M.L.; Li, H.; Poh, A.M.; Kirkegard, D.; Towers, M.; Upham, J.W. Budesonide and Formoterol Reduce Early Innate Anti-Viral Immune Responses in Vitro. PLoS One 2011, 6, e27898, doi:10.1371/journal.pone.0027898.

110. Dora, D.; Rivard, C.; Yu, H.; Bunn, P.; Suda, K.; Ren, S.; Lueke Pickard, S.; Laszlo, V.; Harko, T.; Megyesfalvi, Z.; et al. Neuroendocrine Subtypes of Small Cell Lung Cancer Differ in Terms of Immune Microenvironment and Checkpoint Molecule Distribution. Mol Oncol 2020, 14, 1947-1965, doi:10.1002/1878-0261.12741. 
111. Maneechotesuwan, K.; Supawita, S.; Kasetsinsombat, K.; Wongkajornsilp, A.; Barnes, P.J. Sputum Indoleamine-2, 3-Dioxygenase Activity Is Increased in Asthmatic Airways by Using Inhaled Corticosteroids. J. Allergy Clin. Immunol. 2008, 121, 43-50, doi:10.1016/j.jaci.2007.10.011.

112. Feng, E.; Wan, R.; Yang, S.; Yan, Z.; Wang, S.; He, W.; Zhang, Y.; Yin, H.; Chen, Z.; Liu, R. Expression Levels of Induced Sputum IL-8 and IL-10 and Drug Intervention Effects in Patients with Acute Exacerbated COPD Complicated with Chronic Cor Pulmonale at High Altitude. Exp Ther Med 2013, 6, 747-752, doi:10.3892/etm.2013.1192.

113. Li, H.-T.; Lin, Y.-S.; Ye, Q.-M.; Yang, X.-N.; Zou, X.-L.; Yang, H.-L.; Zhang, T.-T. Airway Inflammation and Remodeling of Cigarette Smoking Exposure Ovalbumin-Induced Asthma Is Alleviated by CpG Oligodeoxynucleotides via Affecting Dendritic Cell-Mediated Th17 Polarization. Int Immunopharmacol 2020, 82, 106361, doi:10.1016/j.intimp.2020.106361.

114. Honda, K.; Wada, H.; Nakamura, M.; Nakamoto, K.; Inui, T.; Sada, M.; Koide, T.; Takata, S.; Yokoyama, T.; Saraya, T.; et al. IL-17A Synergistically Stimulates TNF- $\alpha$-Induced IL-8 Production in Human Airway Epithelial Cells: A Potential Role in Amplifying Airway Inflammation. Exp Lung Res 2016, 42, 205-216, doi:10.1080/01902148.2016.1190796.

115. Zhang, Y.; Wang, H.; Ren, J.; Tang, X.; Jing, Y.; Xing, D.; Zhao, G.; Yao, Z.; Yang, X.; Bai, H. IL-17A Synergizes with IFN- $\gamma$ to Upregulate INOS and NO Production and Inhibit Chlamydial Growth. PLoS One 2012, 7, e39214, doi:10.1371/journal.pone.0039214.

116. He, Q.; Ananaba, G.A.; Patrickson, J.; Pitts, S.; Yi, Y.; Yan, F.; Eko, F.O.; Lyn, D.; Black, C.M.; Igietseme, J.U.; et al. Chlamydial Infection in Vitamin D Receptor Knockout Mice Is More Intense and Prolonged than in Wild-Type Mice. J. Steroid Biochem. Mol. Biol. 2013, 135, 7-14, doi:10.1016/j.jsbmb.2012.11.002.

117. Youssef, D.A.; Miller, C.W.; El-Abbassi, A.M.; Cutchins, D.C.; Cutchins, C.; Grant, W.B.; Peiris, A.N. Antimicrobial Implications of Vitamin D. Dermatoendocrinol 2011, 3, 220 229, doi:10.4161/derm.3.4.15027.

118. Qiu, S.-L.; Kuang, L.-J.; Tang, Q.-Y.; Duan, M.-C.; Bai, J.; He, Z.-Y.; Zhang, J.-Q.; Li, M.-H.; Deng, J.-M.; Liu, G.-N.; et al. Enhanced Activation of Circulating Plasmacytoid Dendritic Cells in Patients with Chronic Obstructive Pulmonary Disease and Experimental Smoking-Induced Emphysema. Clin Immunol 2018, 195, 107-118, doi:10.1016/j.clim.2017.11.003.

119. Theegarten, D.; Anhenn, O.; Hotzel, H.; Wagner, M.; Marra, A.; Stamatis, G.; Mogilevski, G.; Sachse, K. A Comparative Ultrastructural and Molecular Biological Study on Chlamydia Psittaci Infection in Alpha-1 Antitrypsin Deficiency and Non-Alpha-1 Antitrypsin Deficiency Emphysema versus Lung Tissue of Patients with Hamartochondroma. BMC Infect Dis 2004, 4, 38, doi:10.1186/1471-2334-4-38.

120. Wong, C.K.; Ho, C.Y.; Ko, F.W.; Chan, C.H.; Ho, A.S.; Hui, D.S.; Lam, C.W. Proinflammatory Cytokines (IL-17, IL-6, IL-18 and IL-12) and Th Cytokines (IFN-Gamma, 
IL-4, IL-10 and IL-13) in Patients with Allergic Asthma. Clin. Exp. Immunol. 2001, 125, 177183.

121. Zhang, Y.-L.; Luan, B.; Wang, X.-F.; Qiao, J.-Y.; Song, L.; Lei, R.-R.; Gao, W.-X.; Liu, Y. Peripheral Blood MDSCs, IL-10 and IL-12 in Children with Asthma and Their Importance in Asthma Development. PLoS ONE 2013, 8, e63775, doi:10.1371/journal.pone.0063775.

122. Xystrakis, E.; Kusumakar, S.; Boswell, S.; Peek, E.; Urry, Z.; Richards, D.F.; Adikibi, T.; Pridgeon, C.; Dallman, M.; Loke, T.-K.; et al. Reversing the Defective Induction of IL-10Secreting Regulatory $\mathrm{T}$ Cells in Glucocorticoid-Resistant Asthma Patients. J. Clin. Invest. 2006, 116, 146-155, doi:10.1172/JCI21759.

123. Hawrylowicz, C.; Richards, D.; Loke, T.-K.; Corrigan, C.; Lee, T. A Defect in Corticosteroid-Induced IL-10 Production in T Lymphocytes from Corticosteroid-Resistant Asthmatic Patients. J. Allergy Clin. Immunol. 2002, 109, 369-370.

124. Vanders, R.L.; Gibson, P.G.; Wark, P.A.B.; Murphy, V.E. Alterations in Inflammatory, Antiviral and Regulatory Cytokine Responses in Peripheral Blood Mononuclear Cells from Pregnant Women with Asthma. Respirology 2013, 18, 827-833, doi:10.1111/resp.12068.

125. Shima, K.; Coopmeiners, J.; Graspeuntner, S.; Dalhoff, K.; Rupp, J. Impact of MicroEnvironmental Changes on Respiratory Tract Infections with Intracellular Bacteria. FEBS Lett. 2016, 590, 3887-3904, doi:10.1002/1873-3468.12353.

126. Ren, J.; Sun, Y.; Li, G.; Zhu, X.-J.; Cui, J.-G. Tumor Necrosis Factor- $\alpha$, Interleukin-8 and Eosinophil Cationic Protein as Serum Markers of Glucocorticoid Efficacy in the Treatment of Bronchial Asthma. Respir Physiol Neurobiol 2018, 258, 86-90, doi:10.1016/j.resp.2018.06.004.

127. Berry, M.A.; Hargadon, B.; Shelley, M.; Parker, D.; Shaw, D.E.; Green, R.H.; Bradding, P.; Brightling, C.E.; Wardlaw, A.J.; Pavord, I.D. Evidence of a Role of Tumor Necrosis Factor Alpha in Refractory Asthma. N. Engl. J. Med. 2006, 354, 697-708, doi:10.1056/NEJMoa050580.

128. Boulay, M.-E.; Prince, P.; Deschesnes, F.; Chakir, J.; Boulet, L.-P. Metalloproteinase9 in Induced Sputum Correlates with the Severity of the Late Allergen-Induced Asthmatic Response. Respiration 2004, 71, 216-224, doi:10.1159/000077418.

129. Goleva, E.; Hauk, P.J.; Boguniewicz, J.; Martin, R.J.; Leung, D.Y.M. Airway Remodeling and Lack of Bronchodilator Response in Steroid-Resistant Asthma. J. Allergy Clin. Immunol. 2007, 120, 1065-1072, doi:10.1016/j.jaci.2007.07.042.

130. Arno, G.; Kaski, J.C.; Smith, D.A.; Akiyu, J.P.; Hughes, S.E.; Baboonian, C. Matrix Metalloproteinase-9 Expression Is Associated with the Presence of Chlamydia Pneumoniae in Human Coronary Atherosclerotic Plaques. Heart 2005, 91, 521-525, doi:10.1136/hrt.2003.012054. 
131. Paolillo, R.; Iovene, M.R.; Romano Carratelli, C.; Rizzo, A. Induction of VEGF and MMP-9 Expression by Toll-like Receptor 2/4 in Human Endothelial Cells Infected with Chlamydia Pneumoniae. Int $J$ Immunopathol Pharmacol 2012, 25, 377-386, doi:10.1177/039463201202500207.

132. Cataldo, D.D.; Tournoy, K.G.; Vermaelen, K.; Munaut, C.; Foidart, J.-M.; Louis, R.; Noël, A.; Pauwels, R.A. Matrix Metalloproteinase-9 Deficiency Impairs Cellular Infiltration and Bronchial Hyperresponsiveness during Allergen-Induced Airway Inflammation. Am. J. Pathol. 2002, 161, 491-498, doi:10.1016/S0002-9440(10)64205-8.

133. Chiba, N.; Shimada, K.; Chen, S.; Jones, H.D.; Alsabeh, R.; Slepenkin, A.V.; Peterson, E.; Crother, T.R.; Arditi, M. Mast Cells Play an Important Role in Chlamydia Pneumoniae Lung Infection by Facilitating Immune Cell Recruitment into the Airway. J. Immunol. 2015, 194, 3840-3851, doi:10.4049/jimmunol.1402685.

134. Walsh, G.M. Biologics Targeting IL-5, IL-4 or IL-13 for the Treatment of Asthma - an Update. Expert Rev Clin Immunol 2017, 13, 143-149, doi:10.1080/1744666X.2016.1216316.

135. Dominguez-Ortega, J.; Delgado, J.; Blanco, C.; Prieto, L.; Arroabarren, E.; Cimarra, M.; Henriquez-Santana, A.; Iglesias-Souto, J.; Vega-Chicote, J.M.; Tabar, A.I. Specific Allergen Immunotherapy for the Treatment of Allergic Asthma: A Review of Current Evidence. J Investig Allergol Clin Immunol 2017, 27, 1-35, doi:10.18176/jiaci.0149. 
11. Annexes 
I. 


\title{
Beneficial Immunomodulatory Effects of Fluticasone Propionate in Chlamydia pneumoniae-Infected Mice
}

\author{
Dóra Paróczai ${ }^{1,2, *(\mathbb{D}}$, Anita Sejben ${ }^{3}$, Dávid Kókai ${ }^{2}$, Dezső P. Virok ${ }^{2}$, Valéria Endrész ${ }^{2} \mathbb{C}$ and Katalin Burián ${ }^{2} \mathbb{C}$ \\ 1 Department of Pulmonology, University of Szeged, Alkotmány str. 36., 6772 Deszk, Hungary \\ 2 Department of Medical Microbiology and Immunobiology, University of Szeged, Dóm sqr. 10. \\ 6720 Szeged, Hungary; kokai.david@med.u-szeged.hu (D.K.); virok.dezso.peter@med.u-szeged.hu (D.P.V.); \\ endresz.valeria@med.u-szeged.hu (V.E.); burian.katalin@med.u-szeged.hu (K.B.) \\ 3 Department of Pathology, University of Szeged, Állomás str. 1., 6720 Szeged, Hungary; \\ sejben.anita@med.u-szeged.hu \\ * Correspondence: paroczai.dora@med.u-szeged.hu
}

Citation: Paróczai, D.; Sejben, A.; Kókai, D.; Virok, D.P.; Endrész, V.; Burián, K. Beneficial

Immunomodulatory Effects of Fluticasone Propionate in Chlamydia pneumoniae-Infected Mice. Pathogens 2021, 10, 338. https://doi.org/ $10.3390 /$ pathogens 10030338

Academic Editor: Lee Ann Campbell

Received: 17 February 2021

Accepted: 12 March 2021

Published: 14 March 2021

Publisher's Note: MDPI stays neutral with regard to jurisdictional claims in published maps and institutional affiliations.

Copyright: (c) 2021 by the authors. Licensee MDPI, Basel, Switzerland. This article is an open access article distributed under the terms and conditions of the Creative Commons Attribution (CC BY) license (https:// creativecommons.org/licenses/by/ $4.0 /)$.

\begin{abstract}
The associations between inhaled corticosteroid (ICS) use and pulmonary infections remains controversial. Chlamydia pneumoniae (C. pneumoniae) accounts for asthma exacerbations; however, there are no data regarding ICS effects on C. pneumoniae infections. Thus, we investigated whether fluticasone propionate (FP) or budesonide (BUD) could affect $C$. pneumoniae infection in vitro and in vivo, focusing on the possible mechanisms that lead to potential anti-chlamydial outcomes. We performed direct qPCR to detect $C$. pneumoniae growth in infected, FP-treated, and BUD-treated A549 cells. Furthermore, FP or BUD was administered by inhalation to C. pneumoniae-infected mice. The recoverable C. pneumoniae was determined by indirect immunofluorescence. Expression levels of interferon (IFN)- $\gamma$ and IFN- $\gamma$ inducible chemokines were assessed by qPCR. We measured the protein concentrations of IFN- $\gamma$ and of other cytokines that potentially participate in the anti-chlamydial response by ELISA. We found that FP treatment suppressed Chlamydia growth in A549 cells and in mice. Higher levels of IFN- $\gamma$ gene expression were observed in FP-treated mice compared to the untreated and BUD-treated mice $(p<0.0001)$. IFN- $\gamma$ and anti-chlamydial protein MIG/CXCL9 values were significantly higher after FP inhalation. Collectively, FP, but not BUD, suppressed C. pneumoniae growth in vitro and in vivo, which was likely due to the enhanced IFN- $\gamma$ related responses.
\end{abstract}

Keywords: inhaled corticosteroid; fluticasone; Chlamydia pneumoniae; respiratory infection; chemokine; interferon

\section{Introduction}

Inhaled corticosteroids (ICSs) are regarded as the most effective treatment for asthma and chronic obstructive pulmonary disease (COPD) to reduce the risk of exacerbation and improve lung function; however, ICSs have been associated with increased risk of pneumonia [1]. Earlier studies have provided controversial data about the potential risk of pneumonia in patients using ICSs and emphasise the differences in their mechanisms of action [2,3]. It is well established that budesonide (BUD) and fluticasone propionate (FP) show differences in their pharmacokinetic, physicochemical, and even in immunosuppressive properties, which can explain their distinct effects on respiratory infections and exacerbations $[4,5]$. As ICSs may have anti-inflammatory effects on the outcomes of respiratory infections, BUD and FP were studied to determine whether they can affect common viral or bacterial infections associated with COPD and asthma exacerbations. Previous studies have revealed that BUD can inhibit rhinovirus replication and beneficially modulate cytokine responses in vitro depending on the type of infected cell [6,7]. Although both BUD and FP can suppress pro-inflammatory cytokine expression, BUD had a greater impact on antimicrobial proteins [8]. Furthermore, BUD came into focus during the SARS-CoV-2 pandemic, and it was examined in coronavirus $\mathrm{HCoV}-229 \mathrm{E}$ infection, where 
it was found to decrease the expression of the viral entry receptor and infection-induced cytokines, especially interleukin (IL)-6, IL-8, and interferon (IFN)- $\gamma$, resulting in inhibited viral replication in vitro [9]. The transcription of genes involved in cytokine and chemokine responses, particularly CCL-5, also known as RANTES (regulated on activation, normal T cell expressed and secreted); and nuclear factor $\kappa \mathrm{B}$ (NF- $\mathrm{\kappa B})$-dependent gene expression, is altered more extensively by FP than by BUD [10].

However, it remains unclear why ICSs have different effects on the immune responses to respiratory infections. FP has been reported to cause a ten-fold more potent inhibitory effect on airway immune cells and pro-inflammatory cytokine production due to its prolonged presence in the airway mucus, as compared to BUD [11,12]. Since BUD is in conjugated form intracellularly and creates a depot before it is activated [13], its effect is still unexplained in intracellular bacterial infections. In contrast to in vitro studies, BUD attenuated pulmonary antibacterial host defence and increased the number of viable bacteria in mouse lungs [14].

Chlamydia pneumoniae (C. pneumoniae) is an obligate intracellular bacterium that propagates in respiratory epithelial cells, is responsible for community-acquired atypical pneumonia, bronchitis, pharyngitis, sinusitis, and is implicated in the development of severe asthma and acute exacerbations $[15,16]$. We have previously revealed that a former $C$. pneumoniae infection was associated with altered cytokine responses in patients with asthma [17]. However, to our knowledge, the consequences of ICS use on C. pneumoniae infection have not been investigated yet. To address the question of whether ICS use could directly or indirectly influence $C$. pneumoniae infection, we investigated the effects of FP and BUD treatment in an infected mouse model. We hypothesised that $C$. pneumoniae replication and infection-induced immune responses, especially anti-chlamydial IFN- $\gamma$, IFN-related chemokine production, and IFN- $\gamma$ triggered gene expressions, could be influenced by the administration of ICSs. Since BUD and FP have different immunomodulatory effects, they can cause distinct alterations in the immune response to C. pneumoniae infection. To investigate this, we assessed the effects of FP and BUD on the in vitro and in vivo growth of C. pneumoniae in airway epithelial cells and in mice.

\section{Results}

\subsection{FP Suppressed C. pneumoniae Replication in A549 Cells}

We tested C. pneumoniae-infected A549 cells to investigate whether FP or BUD treatment could modulate bacterial growth. As shown earlier, assessment of chlamydial genome concentration by direct qPCR correlated with manual fluorescent microscopic quantitation, wherein qPCR was used to measure the concentration of Chlamydia in infected cells [18]. We assessed C. pneumoniae growth in FP- and BUD-treated epithelial cells based on the cycle threshold $(\mathrm{Ct})$ values. FP treatment resulted in significantly higher $\mathrm{Ct}$ values, indicating suppressed C. pneumoniae growth, compared to that measured in BUD-treated (32.35 \pm 0.51 vs. $30.81 \pm 0.55, p<0.01)$ and untreated control $(32.35 \pm 0.51$ vs. $31.41 \pm 0.39, p<0.01)$ cells. BUD treatment did not affect $C$. pneumoniae growth significantly (Figure 1). Given that our in vitro observations could have significant clinical relevance, we next addressed the elucidation of possible immunomodulating effects of FP and BUD in mice to explore the underlying mechanisms. 


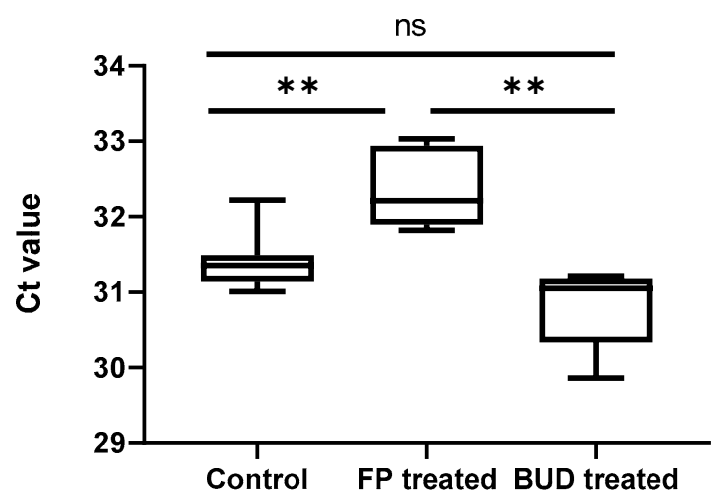

Figure 1. C. pneumoniae growth in A549 cells treated with budesonide (BUD) or fluticasone propionate (FP). A549 cells were treated with BUD or FP for $24 \mathrm{~h}$ before, and for $48 \mathrm{~h}$ after infection with C. pneumoniae (0.01 MOI). Growth of C. pneumoniae was estimated by direct qPCR, as described in the Materials and Methods section. The concentration of C. pneumoniae is shown in terms of Ct value. Error bars denote the mean $\pm \mathrm{SD}$ of five parallel cultures. Asterisks indicate significant differences, ** $p<0.01$; ns means not significant difference.

\subsection{FP Inhibited C. pneumoniae Growth in the Lungs of Mice}

We found that the viable number of $C$. pneumoniae was significantly lower in FP-treated mice compared to the control group $\left(5.33 \times 10^{4} \pm 3.42 \times 10^{4}\right.$ inclusion-forming unit (IFU) $/ \mathrm{mL}$ vs. $1.13 \times 10^{5} \pm 1.28 \times 10^{5} \mathrm{IFU} / \mathrm{mL}, p<0.0001$ ) (Figure 2 ). A similar trend was observed upon comparing FP-treated mice with BUD-treated mice $\left(5.33 \times 10^{4} \pm 3.42 \times 10^{4} \mathrm{IFU} / \mathrm{mL}\right.$ vs. $\left.1.15 \times 10^{5} \pm 1.42 \times 10^{4} \mathrm{IFU} / \mathrm{mL}, p<0.001\right)$. In contrast, no inhibition was detected in BUD-treated mice compared to the control (Figure 2).

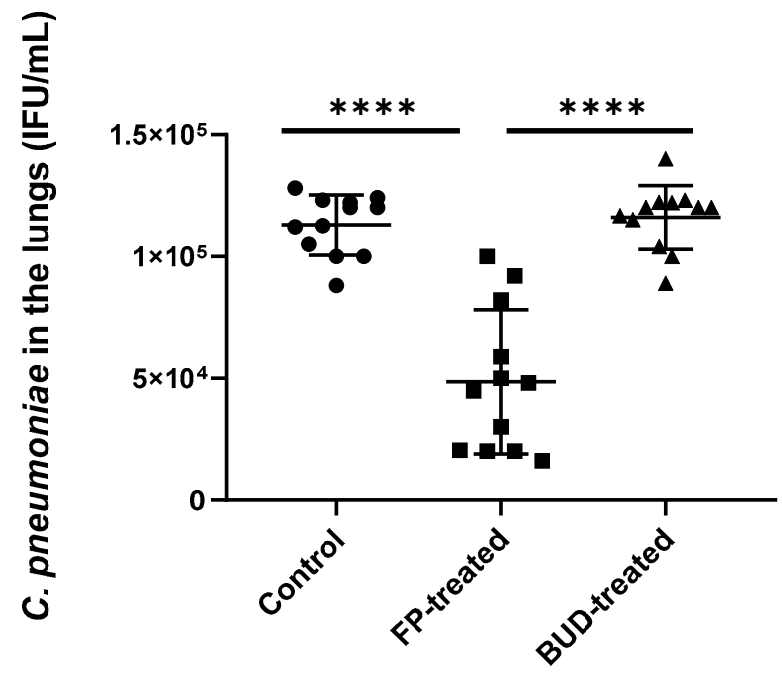

Figure 2. Quantity of recoverable C. pneumoniae in mouse lungs. Supernatants of lung homogenates were cultured on McCoy cells, and the number of recoverable C. pneumoniae was counted by indirect immunofluorescence test after two days of incubation. Symbols show data from individual mice. Horizontal lines indicate mean \pm SD. Significant differences are indicated by asterisks, ${ }^{* * * *} p<0.0001$.

\subsection{Effects of FP and BUD on Chlamydia-Infected Lung Tissue Histopathology}

In the haematoxylin-eosin (HE)-stained mouse lung tissues, a distinctive difference in the general blueish appearance of the background in the control and BUD-treated specimen was observed, which was caused by extensive lymphoid infiltration. Even though the inflammation appeared diffusely, accentuated perivascular and peribronchial infiltration was also observed at higher magnification (Figure 3A,B). Similarly, in the FP-treated 
mouse lung tissues, lymphocytic and plasmacytic infiltration was observed; centriacinar emphysema was also visible, with thin alveolar septa (Figure 3C).

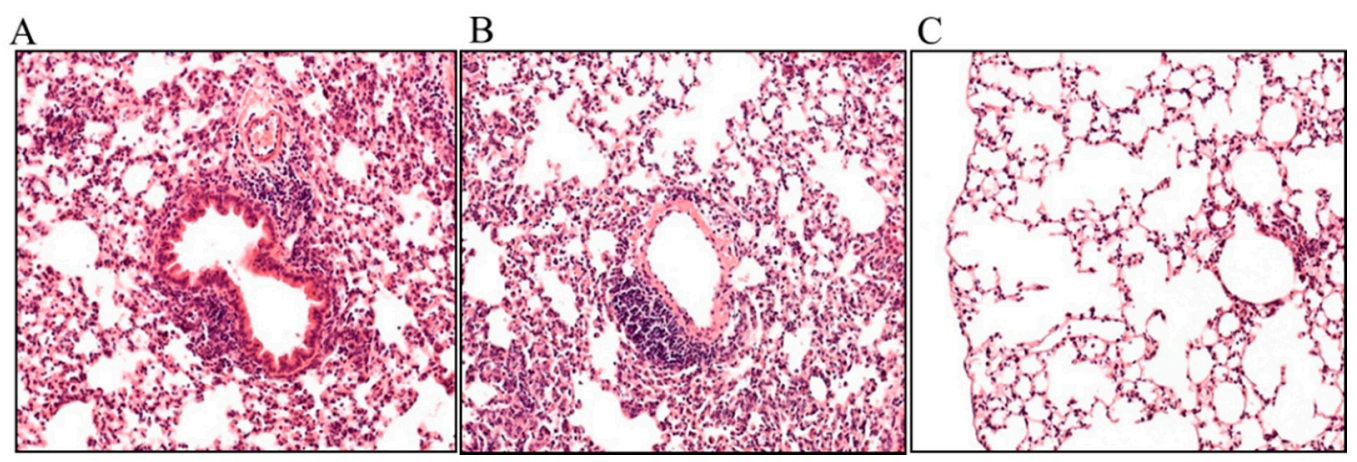

Figure 3. The effects of inhaled corticosteroids (ICSs) on Chlamydia-induced histopathology in BALB/c mouse lung tissues. Representative HE-stained sections of C. pneumoniae-infected, untreated (A), C. pneumoniae-infected, BUD-treated (B), and C. pneumoniae-infected, FP treated (C) lung tissues (magnification $200 \times$ ).

\subsection{Effects of FP and BUD Treatment on Gene Expressions Related to IFN- $\gamma$ and Corticosteroid Responses in C. pneumoniae Infected Mice}

Next, we explored whether the expression of IFN- $\gamma$ and IFN- $\gamma$ induced genes was altered in FP- and BUD-treated lung tissues, including the typical, inducible defence genes against Chlamydia infection, such as indoleamine 2,3-dioxygenase 1 (IDO1), IDO2, MIG/CXCL9, IP-10/CXCL10 and I-TAC/CXCL11. qPCR using total RNA isolated from homogenised lung tissues revealed that the relative expression of IFN- $\gamma$ was significantly enhanced in FP-treated mice $(p<0.001)$ compared to BUD-treated and control mice, the relative expression was $12.8 \pm 5.8$ vs. $0.9 \pm 0.43$ and $12.8 \pm 5.8$ vs. $0.75 \pm 0.1$, respectively (Figure 4A).
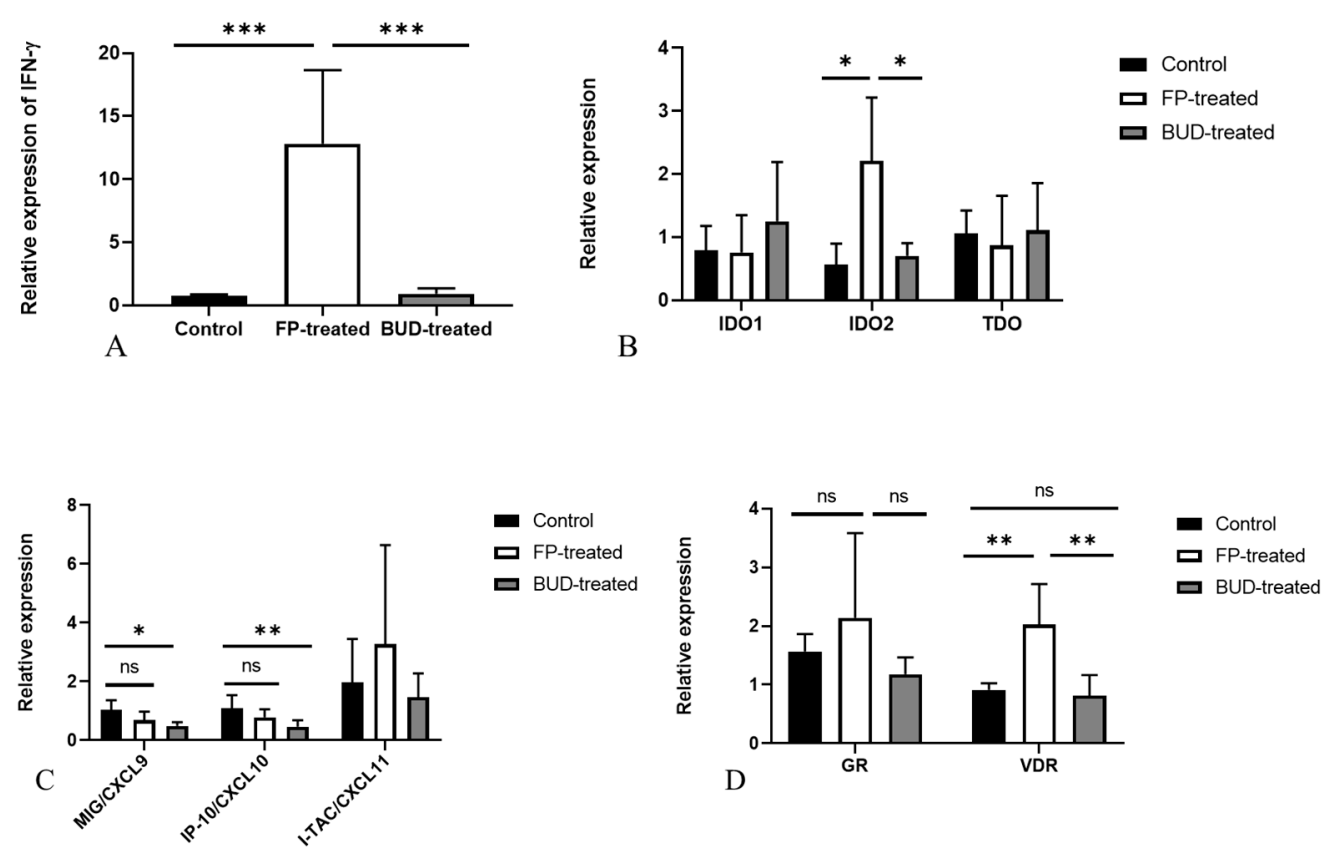

Figure 4. Relative gene expressions in C. pneumoniae-infected and treated mouse lungs. Gene expression of IFN- $\gamma$ (A), IDO1, IDO2, TDO (B), IFN- $\gamma$-inducible chemokines (C), VDR, and GR (D) determined by qPCR. Relative expression was normalised to $\beta$-actin gene expression and calculated by the $2^{-(\Delta \Delta C t)}$ method. Significant differences are indicated with asterisks, ${ }^{*} p<0.05,{ }^{* *} p<0.01,{ }^{* * *} p<0.001$; ns means not significant difference. 
Our previous studies showed that the IFN- $\gamma$ inducible IDO1 and IDO2 are highly expressed in C. pneumoniae-infected mouse lungs [19]. Thus, we next investigated the effects of FP and BUD treatment on the expression of IFN- $\gamma$ inducible IDO1, IDO2, and tryptophan 2,3-dioxygenase (TDO) involved in the metabolism of amino acid tryptophan that is essential for Chlamydia growth. Our results indicated a significantly increased IDO2 expression in the FP-treated mice compared to the control and BUD-treated group $(p<0.05)$. This phenomenon was not observed in IDO1 and TDO expression (Figure 4B).

To test the consequence of increased IFN- $\gamma$ release, we determined the relative expression levels of IFN- $\gamma$ related chemokines. Unexpectedly, we found that BUD significantly decreased the expression of MIG/CXCL9 $(p<0.05)$ and IP-10/CXCL10 $(p<0.01)$ compared to untreated C. pneumoniae infected control mice. However, the relative expression of MIG/CXCL9 and IP-10/CXCL10 was not altered significantly in FP-treated mice. ITAC/CXCL11 showed similar expression levels in all groups (Figure 4C).

Furthermore, we investigated the expression of glucocorticoid receptor (GR) and Vitamin D receptor (VDR) genes, as both receptors perform immunomodulatory functions $[20,21]$. Interestingly, our results demonstrated that FP treatment increased VDR expression significantly compared to control and BUD-treated mice $(p<0.01)$, whereas BUD treatment did not affect VDR expression. We found no statistically significant difference in GR expressions in C. pneumoniae-infected BUD- and FP-treated mice (Figure 4D).

\subsection{Anti-Chlamydial IFN- $\gamma$ and MIG/CXCL9 Protein Production Are Enhanced by FP Treatment}

As previously described, IFN- $\gamma$ exhibits crucial anti-chlamydial activity by inducing chemokine production and increasing anti-chlamydial gene expression [22]. To determine whether ICSs altered gene expression, and influenced the levels of IFN- $\gamma$ and related chemokines, we estimated IFN- $\gamma$ and MIG/CXCL-9 protein concentrations in the supernatants of lung homogenates for C. pneumoniae-infected mice (Figure 5). According to our results, IFN- $\gamma$ production was significantly increased after FP treatment compared to untreated infected control $(4519.77 \pm 1289.08 \mathrm{pg} / \mathrm{mL}$ vs. $2060.07 \pm 995.76 \mathrm{pg} / \mathrm{mL}, p<0.05)$. BUD treatment did not affect IFN- $\gamma$ production significantly compared to FP-treated or control mice.

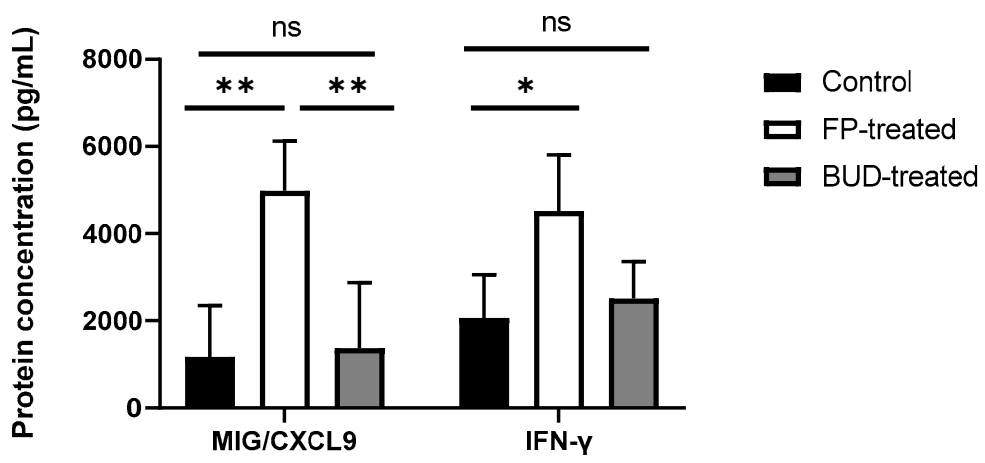

Figure 5. Effect of ICSs on IFN- $\gamma$ and MIG/CXCL9 production in C. pneumoniae-infected mouse lungs. IFN- $\gamma$ and MIG/CXCL9 protein concentrations were determined by ELISA in the supernatants of homogenised lung tissues of infected FP-treated, BUD-treated, and untreated mice. Data are shown as $\mathrm{pg} / \mathrm{mL}$. Bars denote mean $\pm \mathrm{SD}$ of each group $(\mathrm{n}=12)$. Significant differences are indicated with asterisks, ${ }^{*} p<0.05,{ }^{* *} p<0.01$; ns means not significant difference.

We examined whether MIG/CXCL9 production at the protein level was changed in association with alterations in IFN- $\gamma$ production in vivo. We found that FP-treated mice showed a higher protein level of MIG/CXCL9, compared to that in untreated controls $(4984 \pm 1137 \mathrm{pg} / \mathrm{mL}$ vs. $1169 \pm 1178 \mathrm{pg} / \mathrm{mL}, p<0.01)$. Furthermore, a significant increment in the level of MIG/CXCL9 was detected in FP-treated lung tissues compared to the BUD-treated mouse lungs $(4984 \pm 1137 \mathrm{pg} / \mathrm{mL}$ vs. $1370 \pm 1509 \mathrm{pg} / \mathrm{mL}, p<0.01)$ (Figure 5). 


\subsection{Effects of BUD and FP Treatment on the Secretion of Th17 and Th2 Cytokines in C. pneumoniae-Infected Lung Tissues}

ELISA of supernatants from control and treated lung samples was performed to elucidate the influence of ICS treatment on cytokine production. As previously reported by us, IL-17A has an indirect anti-chlamydial activity in vivo [23]. Thus, we investigated the impact of ICSs on IL-17A production in infected mouse lungs (Figure 6A). We found a significantly elevated IL-17A level in FP-treated mouse lungs compared to the control group $(55.59 \pm 17.7 \mathrm{pg} / \mathrm{mL}$ vs. $3.06 \pm 0.67 \mathrm{pg} / \mathrm{mL}, p<0.01)$. Although increased IL-17A production was observed in BUD-treated mice, it did not differ significantly from the control and FP- treated mice.

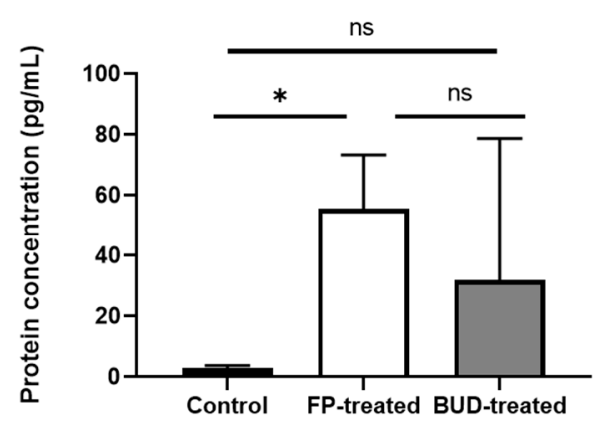

A

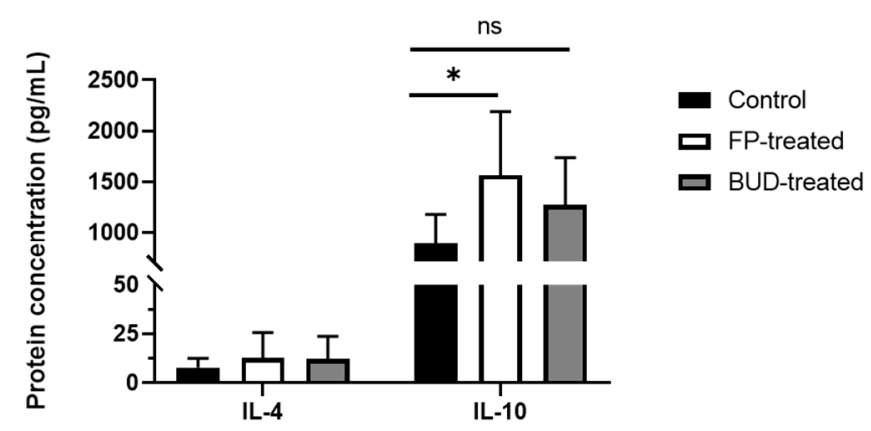

B

Figure 6. Effects of BUD and FP on the secretion of interleukin (IL)-17A, IL-4 and IL-10 in control and treated mice. IL-17A (A), IL-4, and IL-10 (B) protein concentrations were determined by ELISA in the supernatants of homogenised lung tissues of infected FP-treated, BUD-treated, and untreated mice. Bars denote mean \pm SD of each group $(\mathrm{n}=12) .{ }^{*} p<0.05$, ns means not significant difference.

As Th2 cytokines play a pivotal role in modulating lung inflammation, we evaluated whether FP and BUD could affect IL-4 and IL-10 secretion in C. pneumoniae-infected mice (Figure 6B). Our results indicated unaltered IL-4 production, whereas IL-10 levels changed in a different manner. We detected a significantly higher amount of IL-10 in FP-treated lung tissues, but not in the BUD-treated lungs, in comparison with the untreated infected mice $(1757.28 \pm 602.93 \mathrm{pg} / \mathrm{mL}$ vs. $739.67 \pm 19.70 \mathrm{pg} / \mathrm{mL}, p<0.05)$.

\section{Discussion}

ICSs are widely used to treat COPD and asthma, as they show a broad range of antiinflammatory properties and improve lung function. However, the association between ICS use and the risk of pneumonia remains unclear, as different ICSs have distinct effects on infections. Several studies have been conducted to reveal their possible connection to respiratory infections; nevertheless, clinical data tend to be contradictory [2,24,25]. ICSs have different pharmacological and immunomodulatory effects considering responses to viral infections, immune cell functions, and cytokine production [4]. As exacerbations of obstructive lung diseases are mainly caused by viral or bacterial infections, ICSs were investigated from a new perspective, and their effects on antimicrobial defence were examined.

FP and BUD affected pro-inflammatory epithelial responses, and they presented antiviral and anti-inflammatory activities differentially. In vitro studies have shown that BUD is effective in counteracting rhinovirus replication, inhibiting cytokine production, and enhancing antimicrobial protein secretion; however, in vivo, it suppressed pulmonary host defence genes that are essential for bacterial clearance $[6,14,26,27]$. Moreover, inhalation of BUD has been shown to lead to significant alterations in the regulation of anti- and pro-inflammatory genes involved in eliminating respiratory pathogens [28].

FP is regarded as a more potent inhibitor of pro-inflammatory genes and cytokines, although it can preserve the production of several cytokines, especially IFN- $\gamma$, to reverse its exaggerated effect on Th2 response in allergic inflammation. Inhibitory effects of this 
topically active ICS are not well-established in respiratory infections, despite the fact that FP is far more potent in cytokine production than other ICSs [29].

C. pneumoniae is implicated in asthma exacerbations, and there is increasing evidence indicating that it plays a role in asthma pathogenesis, leading to altered cytokine responses, decreased lung function, and heightened disease severity [30-32]. Thus, we aimed to investigate whether ICSs could have beneficial modulatory effects on Chlamydia infection in vitro and in vivo, and thus, define the possible underlying mechanisms.

Collectively, our reported data inspire several exciting concepts that could have practical outcomes for respiratory physicians. Our in vitro results suggest that $C$. pneumoniae growth is suppressed in infected epithelial cells by FP but not by BUD. Thus, we tested our hypothesis whether FP could inhibit the growth of $C$. pneumoniae in vivo. We found that the number of recoverable $C$. pneumoniae decreased in $C$. pneumoniae-infected mouse lungs after FP treatment, as observed in A549 epithelial cells. It is well established that the IFN- $\gamma$ is the main regulator of Chlamydia elimination and can trigger various mechanism leading to Chlamydia inhibition. IFN- $\gamma$ exposure induced IDO activity, which is responsible for tryptophan degradation. As Chlamydiae are tryptophan auxotrophs, increased IDO activity results in a restricted Chlamydia growth in vitro and in vivo [19,33]. Moreover, IFN- $\gamma$ enhances the expression of genes involved in innate immunity, thus contributing further to the mechanisms inhibiting Chlamydia infections [34]. Our findings revealed that FP can significantly induce IFN- $\gamma$ not only at the transcription level but also at the protein level, in contrast to BUD, indicating the previously described phenomenon that FP preserves IFN- $\gamma$ responses [29]. IFN- $\gamma$ associated MIG/CXCL9 was shown to have an antimicrobial effect to C. pneumoniae [35], similar to C. trachomatis and C. muridarum [34]. Our results demonstrated that MIG/CXCL9 levels increased at the protein level in parallel with IFN- $\gamma$ after FP administration, compared to that in untreated control and BUD-treated mouse lungs. Interestingly, FP did not alter the expression of other IFN- $\gamma$-inducible chemokines, suggesting that other mechanisms may be playing a role in chemokine expression. Notably, BUD treatment significantly reduced the gene expression levels of CXCL-10 and CXCL-11, which is in accordance with a previous report [36]. Consistently, ICS treatments have a unique impact on IFN- $\gamma$ response and chemokine production.

IDO activity is a hallmark of tryptophan depletion and suppression of Chlamydia growth in cell cultures and mice. Furthermore, IDO activity is associated with several pulmonary diseases, including lung cancer [37]. Sputum IDO activity was enhanced in an IL-10 dependent manner in asthmatic patients receiving ICSs; the ICSs increased IL-10 secretion from macrophages in parallel with IDO activity, indicating that ICS use could generate IDO activity through IL-10 production [38]. Our results also indicate a significant increase in IL-10 production after FP administration in infected mice; conversely, BUD did not have an enhancing effect. Since it is well-known that FP can increase local secretion of IL-10 in vivo [39], we concluded that the observed IDO activity could have been derived from the additive effects of IFN- $\gamma$ and IL- 10 .

To further analyse the production of anti-chlamydial cytokines, we measured IL-17A levels, as it has been reported to trigger neutrophil recruitment in the lung, whereas its neutralisation results in a higher C. pneumoniae burden [23]. FP was not able to inhibit IL17A, in contrast to BUD, which downregulates IL-23, the potential inducer of IL-17A [40,41]. Our current findings revealed that FP-treated mice produced significantly higher amounts of IL-17A in response to C. pneumoniae infection, suggesting that this increase in IL-17A production might also result in the development of $C$. pneumoniae inhibition; as observed in a previous study, IL-17A can synergise with IFN- $\gamma$, playing a protective role in Chlamydia infection [42].

Lastly, we analysed the relative expression of GR and VDR, and we found that FP treatment significantly increased VDR expression compared to control and BUD-treated mice. VDR is one of the highly downregulated transcription factors in Chlamydia-infected murine cells [34], suggesting that the elevated VDR expression in our study was due to the influence of FP in mice. This result raises the likelihood of the beneficial impact of FP to 
stem from VDR activation; a former study proved that the diminished VDR activity was associated with higher Chlamydia load in the lungs [43]. Vitamin D favours the curtailment of bacterial infections, and it had several implications in modulating adaptive and innate immunity to eliminate bacterial infections [44]. Therefore, our results raise the possibility that FP supports VDR functions, which can further influence cytokine and chemokine production. Thus, we recommend further examination of the interaction between ICS use and VDR activity, as Vitamin D supplementation is widely recommended in asthma.

In addition, we investigated whether FP or BUD could amend the histopathology of C. pneumoniae-infected mouse lungs and found that all specimens contained lymphocyte infiltration as a sign of C. pneumoniae infection. However, emphysema was also visible in FP-treated lung samples. As FP treatment showed an exaggerated IFN- $\gamma$ response to the Chlamydia infection, the elimination of C. pneumoniae through enhanced cytokine and chemokine production could lead to minimal emphysema in infected lungs. According to previous studies [45,46], emphysema can be associated with the IFN- $\gamma$ production and Chlamydia infections.

To our knowledge, this is the first study that investigates the effects of FP and BUD on C. pneumoniae infection in vivo and in vitro. The most notable results of our research are as follows: (1) FP treatment inhibited C. pneumoniae growth in A549 cells; (2) FP also inhibited C. pneumoniae replication in vivo; (3) FP induced IFN- $\gamma$ at the gene expression and protein levels, leading to enhanced IDO activity and MIG/CXCL9 production; (4) FP promoted the expression of VDR.

\section{Materials and Methods}

\subsection{In Vitro Study Design}

A549 human airway epithelial cells (ATCC, Manassas, VA, USA) were transferred to a 96-well plate at a density of $4 \times 10^{4}$ cells /well in $100 \mu \mathrm{L}$ of minimal essential medium (MEM) with Earle's salts supplemented with 10\% heat-inactivated foetal bovine serum (FBS), $2 \mathrm{mmol} / \mathrm{L}$-glutamine, $1 \mathrm{x}$ non-essential amino acids, $4 \mathrm{mM}$ HEPES and $25 \mu \mathrm{g} / \mathrm{mL}$ gentamycin. The cells were pre-treated and incubated for $24 \mathrm{~h}$ at $37^{\circ} \mathrm{C}, 5 \% \mathrm{CO}_{2}$ with FP (Sigma-Aldrich, Saint Louis, MO, USA) or BUD (Sigma-Aldrich, Saint Louis, MO, USA) or left untreated. The highest non-toxic drug concentrations (FP: $3.5 \times 10^{-4} \mathrm{mM}$, BUD: $7 \times 10^{-4} \mathrm{mM}$ ) determined by the 3-(4,5-dimethylthiazol -2yl)-2,5-diphenyl-2H-tetrazolium bromide (MTT) cytotoxicity test. After $24 \mathrm{~h}$ treatment, the wells were washed twice with phosphate-buffered saline (PBS) and the cells were infected with C. pneumoniae at a multiplicity of infection (MOI) of 0.01 . The cells were inoculated in $0.5 \%(w / v)$ glucose medium and centrifuged $(800 \times g, 60 \mathrm{~min})$, which was followed by the addition of FP or BUD to the wells. Control-infected cells were left untreated. After infection, the plates were incubated at $37^{\circ} \mathrm{C}$, under $5 \% \mathrm{CO}_{2}$ for $48 \mathrm{~h}$. Subsequently, the wells were washed twice with PBS, and $100 \mu \mathrm{L}$ sucrose-phosphate-glutamic acid (SPG) solution was added to each well. The plates were subjected to two freeze-thaw cycles with a quick freezing $\left(-80{ }^{\circ} \mathrm{C}, 15 \mathrm{~min}\right)$ to obtain cell lysates, which were used directly as templates for quantitative polymerase chain reaction (qPCR). To evaluate C. pneumoniae propagation, direct qPCR was performed as described previously $[18,47]$.

\subsection{Inoculum Preparation and Immunostaining}

C. pneumoniae strain CWL-029, kindly gifted by Agathe Subtil (Pasteur Institute, Paris, France), was propagated on HEp-2 cells as described previously [48]. The elementary bodies (EBs) were purified and concentrated, and subsequently aliquoted in SPG, which was followed by storage at $-80{ }^{\circ} \mathrm{C}$ until further use. Indirect immunofluorescence was performed to determine the concentration of infectious C. pneumoniae EBs. Serial dilutions of purified EBs were inoculated onto McCoy cell monolayers (ECACC, London UK). After incubation for $48 \mathrm{~h}$, the infected cells were fixed with acetone at $-20^{\circ} \mathrm{C}$ and stained with monoclonal anti-Chlamydia LPS antibody (AbD Serotec, Oxford, UK) and fluorescein isothiocyanate (FITC)-labelled anti-mouse immunoglobulin (Ig) G (Sigma-Aldrich, St. Louis, 
MO, USA). The number of $C$. pneumoniae inclusions was counted under a UV microscope, and the titre was expressed as inclusion-forming units (IFUs) $/ \mathrm{mL}$.

\subsection{Corticosteroid Treatment in Mice}

FP and BUD powder were obtained, and dimethyl sulfoxide (DMSO) was used as a vehicle for the drugs. Mice were exposed to nebulised BUD $(40 \mu \mathrm{g}, 1000 \mu \mathrm{g} / \mathrm{kg})$ and FP $(25 \mu \mathrm{g}, 625 \mu \mathrm{g} / \mathrm{kg})$ in an inhalation chamber for $15 \mathrm{~min}$ once a day, as described previously [49]. We used BUD and FP at equivalent concentrations with the ratio FP:BUD = 1:1.6, based on former clinical studies [50] and the higher potency of FP [10].

\subsection{Animals and Experimental Design}

Female BALB/c mice (6-8-weeks-old) were obtained from Charles River Laboratories (Hungary). The mice were kept under standard husbandry conditions at the animal facility of the Department of Medical Microbiology and Immunobiology, University of Szeged. Animals were fed regular mouse chow and provided with water ad libitum. The mice were randomly divided into three groups: the control, the BUD-treated, and FP-treated ( $\mathrm{n}=16$ in each group). Mice received either BUD, FP, or vehicle alone, for three days prior to infection, and then for seven days after infection. On day 3, the mice were sedated with intraperitoneal injection of sodium pentobarbital $(200 \mu \mathrm{L}, 7.5 \mathrm{mg} / \mathrm{mL})$ and were infected with $5 \times 10^{5}$ IFU C. pneumoniae in $20 \mu \mathrm{L}$ SPG. On day 10, i.e., seven days after infection, the mice were anaesthetised and sacrificed. The lungs were removed and homogenised with acid-purified sea sand (Fluka Chemie AG, Buchs, Switzerland) using a mortar with a pestle. One half of the homogenised lungs was prepared for total RNA extraction, and the other half was suspended in $1 \mathrm{~mL}$ SPG for the detection of recoverable C. pneumoniae and for cytokine measurements. The experiments were implemented with the approval of the Animal Welfare Committee of the University of Szeged, Hungary and conformed to the Directive 2010/63/EU.

\subsection{Culturing of C. pneumoniae from the Lungs}

One half of the homogenised lungs was centrifuged $(10 \mathrm{~min}, 400 \times \mathrm{g})$, and serial dilutions of the supernatants were inoculated onto McCoy cell monolayers and centrifuged $(60 \mathrm{~min}, 800 \times g)$. The number of recoverable C. pneumoniae inclusions was determined by indirect immunofluorescence as described earlier, and expressed in terms of IFU $/ \mathrm{mL}$.

\section{6. mRNA Extraction and cDNA Synthesis}

Total RNA was extracted from the other half of the homogenised lung tissues of the control ( $n=12)$, as well as BUD- and FP-treated mice ( $n=12$ for each group) using TRI reagent (Sigma-Aldrich, Saint Louis, MO, USA) according to the manufacturer's protocol. Total RNA concentrations and purity were measured using a NanoDrop spectrophotometer (Thermo Scientific, Waltham, MA, USA). First-strand cDNA was synthesised from $2 \mu \mathrm{g}$ of total RNA using Maxima First Strand cDNA Synthesis Kit, and 20 pM random hexamer primer in $20 \mu \mathrm{L}$ reaction buffer according to the manufacturer's protocol (Thermo Fisher Scientific Inc. Waltham, MA, USA).

\section{7. $q P C R$ Validation}

qPCR was performed in a Bio-Rad CFX96 real-time system with SsoFast ${ }^{\mathrm{TM}}$ EvaGreen ${ }^{\circledR}$ qPCR Supermix (Bio-Rad, Hercules, CA, USA) master mix and murine specific primer pairs: $\beta$-actin sense, $5^{\prime}$-TGGAATCCTGTGGCATCCATGAAAC- $3^{\prime} ; \beta$-actin antisense, $5^{\prime}$-TAAAACGCAGCTCAGTAACAGTCCG-3'; IDO1 sense, 5'-GCTTCTTCCTCGTCTCTCT ATTG-3' ${ }^{\prime}$; IDO1 antisense, $5^{\prime}$-TCTCCAGACTGGTAGCTATGT-3' ${ }^{\prime}$;DO2 sense, $5^{\prime}$-CCTGGAC TGCAGATTCCTAAAG-3'; IDO2 antisense, 5'-CCAAGTTCCTGGATACCTCAAC-3'; TDO sense, $5^{\prime}$-GGCATGGCTGGAAAGAACAC-3'; TDO antisense, $5^{\prime}$-CTCCCTGGAGTGCACG GTAT-3'; IFN- $\gamma$ sense, $5^{\prime}$-CAAGTGGCATAGATGTGGAAGA- $3^{\prime}$; IFN- $\gamma$ antisense, $5^{\prime}$-GCTG TTGCTGAAGAAGGTAGTA-3'; MIG/CXCL9 sense, $5^{\prime}$-ACGTAGGTTTCGAGACCAGGGA 
TT-3'; MIG/CXCL9 antisense, 5'-CAACACCAAGTGTTCTGCCACCAA-3'; IP10/CXCL10 sense, $5^{\prime}$-TGGCTAGTCCTAATTGCCCTTGGT-3'; IP10/CXCL10 antisense, 5' -TCAGGACC ATGGCTTGACCATCAT-3 ${ }^{\prime}$; ITAC/CXCL11 sense, $5^{\prime}$-TACCCGAGTAACAGCTGCGACAA A-3'; ITAC/CXCL11 antisense, 5'-TATGAGGCGAGCTTGCTTGGATCT-3'; VDR sense, $5^{\prime}$ TACACCCCCTCACTGGACATGAT-3'; VDR antisense, $5^{\prime}$-CGATGACCTTTTGGATGCTGT AA-3' ; GR sense, 5' -GTTCCTAAGGAAGGTCTGAAGAG-3'; and GR antisense, 5' - -CAATTC TGACTGGAGTTTCC- $3^{\prime}$.

Cycle threshold $(\mathrm{Ct})$ values were calculated for $\beta$-actin, IDO1, IDO2, TDO, IFN- $\gamma$ MIG/CXCL9, IP10/CXCL10, ITAC/CXCL11, VDR, and GR, and the relative gene expression levels were determined by the $2^{-(\Delta \Delta \mathrm{Ct})}$ method. The relative expression level was indicated as $2^{-(\Delta \Delta \mathrm{C})}$, where $\Delta \Delta \mathrm{Ct}=\Delta \mathrm{Ct}$ for the experimental sample $-\Delta \mathrm{Ct}$ for the control sample.

\subsection{Lung Histology}

Microscopic examination of the lungs of infected control as well as BUD-treated and FP-treated mice ( $n=4$ from each group) was performed. After the removal of the lungs, tissues of individual mice were immediately placed into plastic tubes, pre-filled with $10 \%$ formalin, resulting in 1:10 of tissue/formalin ratio. During dissection, tissue samples in the tube were cut into $1 \mathrm{~mm}$ slices and embedded into paraffin blocks. Four-micrometre sections were cut, and regular haematoxylin-eosin (HE) staining was performed. All tissue fragments were examined by light microscopy.

\subsection{Cytokine and Chemokine Measurements from the Lungs}

The supernatants of homogenised lung tissues were centrifuged $(12,000 \times g, 5 \mathrm{~min})$ and enzyme-linked immunosorbent assay (ELISA) for IFN- $\gamma$, IL-4, IL-10, IL17-A, MIG/CXCL-9 was performed according to the manufacturers' instructions. MIG/CXCL-9 concentration was determined using a mouse MIG/CXCL-9 ELISA Kit (Sigma-Aldrich, Saint Louis, MO, USA) and IL-17A was measured using Quantikine mouse IL-17 immunoassay (R\&D Systems, Minneapolis, MN, USA). IFN- $\gamma$, IL-4, and IL-10 concentrations were detected with Invitrogen mouse ELISA kits (Thermo Fisher Scientific Inc., Waltham, MA, USA). Sensitivity for IFN- $\gamma$, IL-4, IL-10, IL-17A, and MIG/CXCL-9 measurement ranges were 15-2000, 4-500, 32-4000, 10.9-700, and 2.741-2000 pg/mL, respectively.

\subsection{Statistical Analysis}

Statistical analysis of data was performed with GraphPad Prism 8.0.1. software, using one-way and two-way ANOVA, and Kruskal-Wallis test. All post hoc comparisons were performed using Tukey's method. Data are expressed as mean \pm standard deviation (SD). Differences at $p<0.05$ were considered statistically significant.

\section{Conclusions}

Our results demonstrate that FP treatment can lead to favourable outcomes in C. pneumoniae infection by enhancing IFN- $\gamma$ responses, and inducing potential antichlamydial cytokine and chemokine production. Our observations revealed that the effects of FP were different from other ICSs; therefore, we hypothesised that FP is beneficial in C. pneumoniae infections. Recently, patients with asthma are controlled in new ways via telemedicine and experienced fewer outpatient visits due to COVID19 pandemic. Therefore, investigating the associations of ICSs use and respiratory infections is especially important to avoid further asthma exacerbations. Our study can contribute to a better management of asthma and C. pneumoniae infections, and it could assist therapeutic choices.

Author Contributions: D.P. conceived, designed, and performed the experiments, analysed the data, and wrote the paper. A.S. prepared lung tissues for histopathological analysis, performed HE staining, interpreted histological findings, and was involved in manuscript writing. D.K. was involved in performing qPCR, ELISA, and statistical analysis. V.E. contributed to animal testing 
and manuscript writing. D.P.V. was involved in interpreting lab data and manuscript writing. K.B. conceived the study design, reviewed the manuscript, and supervised the experiment. All authors have read and agreed to the published version of the manuscript.

Funding: The study was supported by GINOP-2.3.2-15-2016-00012.

Institutional Review Board Statement: The experiments were approved by the Animal Welfare Committee of the University of Szeged, Hungary, and conformed to the Directive 2010/63/EU.

Informed Consent Statement: Informed consent was obtained from all subjects involved in the study.

Data Availability Statement: The data presented in this study are available on request from the corresponding author. The data are not publicly available due to privacy.

Acknowledgments: We thank Müllerné Deák Györgyi and Vigyikánné Váradi Anikó for their excellent technical support, and Dezső Mihály for his assistance in the microscopic pictures. D.P. was supported by the Hungarian Respiratory Foundation.

Conflicts of Interest: The authors declare no conflict of interest.

\section{References}

1. Morjaria, J.B.; Rigby, A.; Morice, A.H. Inhaled Corticosteroid Use and the Risk of Pneumonia and COPD Exacerbations in the UPLIFT Study. Lung 2017, 195, 281-288. [CrossRef]

2. Sin, D.D.; Tashkin, D.; Zhang, X.; Radner, F.; Sjöbring, U.; Thorén, A.; Calverley, P.M.A.; Rennard, S.I. Budesonide and the Risk of Pneumonia: A Meta-Analysis of Individual Patient Data. Lancet 2009, 374, 712-719. [CrossRef]

3. McKeever, T.; Harrison, T.W.; Hubbard, R.; Shaw, D. Inhaled Corticosteroids and the Risk of Pneumonia in People with Asthma: A Case-Control Study. Chest 2013, 144, 1788-1794. [CrossRef] [PubMed]

4. Janson, C.; Stratelis, G.; Miller-Larsson, A.; Harrison, T.W.; Larsson, K. Scientific Rationale for the Possible Inhaled Corticosteroid Intraclass Difference in the Risk of Pneumonia in COPD. Int. J. Chronic Obstr. Pulm. Dis. 2017, 12, 3055-3064. [CrossRef]

5. $\quad$ Belchamber, K.B.; Thomas, C.M.; Dunne, A.E.; Barnes, P.J.; Donnelly, L.E. Comparison of Fluticasone Propionate and Budesonide on COPD Macrophage and Neutrophil Function. Int. J. Chronic Obstr. Pulm. Dis. 2018, 13, 2883-2897. [CrossRef]

6. Yamaya, M.; Nishimura, H.; Nadine, L.; Kubo, H.; Nagatomi, R. Formoterol and Budesonide Inhibit Rhinovirus Infection and Cytokine Production in Primary Cultures of Human Tracheal Epithelial Cells. Respir. Investig. 2014, 52, 251-260. [CrossRef] [PubMed]

7. Bochkov, Y.A.; Busse, W.W.; Brockman-Schneider, R.A.; Evans, M.D.; Jarjour, N.N.; McCrae, C.; Miller-Larsson, A.; Gern, J.E. Budesonide and Formoterol Effects on Rhinovirus Replication and Epithelial Cell Cytokine Responses. Respir. Res. 2013, 14, 98. [CrossRef]

8. Van den Berge, M.; Jonker, M.R.; Miller-Larsson, A.; Postma, D.S.; Heijink, I.H. Effects of Fluticasone Propionate and Budesonide on the Expression of Immune Defense Genes in Bronchial Epithelial Cells. Pulm. Pharmacol. Ther. 2018, 50, 47-56. [CrossRef]

9. Yamaya, M.; Nishimura, H.; Deng, X.; Sugawara, M.; Watanabe, O.; Nomura, K.; Shimotai, Y.; Momma, H.; Ichinose, M.; Kawase, T. Inhibitory Effects of Glycopyrronium, Formoterol, and Budesonide on Coronavirus HCoV-229E Replication and Cytokine Production by Primary Cultures of Human Nasal and Tracheal Epithelial Cells. Respir. Investig. 2020, 58, 155-168. [CrossRef]

10. Jaffuel, D.; Demoly, P.; Gougat, C.; Balaguer, P.; Mautino, G.; Godard, P.; Bousquet, J.; Mathieu, M. Transcriptional Potencies of Inhaled Glucocorticoids. Am. J. Respir. Crit. Care Med. 2000, 162, 57-63. [CrossRef]

11. Ek, A.; Larsson, K.; Siljerud, S.; Palmberg, L. Fluticasone and Budesonide Inhibit Cytokine Release in Human Lung Epithelial Cells and Alveolar Macrophages. Allergy 1999, 54, 691-699. [CrossRef]

12. Edsbäcker, S.; Wollmer, P.; Selroos, O.; Borgström, L.; Olsson, B.; Ingelf, J. Do Airway Clearance Mechanisms Influence the Local and Systemic Effects of Inhaled Corticosteroids? Pulm. Pharmacol. Ther. 2008, 21, 247-258. [CrossRef] [PubMed]

13. Miller-Larsson, A.; Mattsson, H.; Hjertberg, E.; Dahlbäck, M.; Tunek, A.; Brattsand, R. Reversible Fatty Acid Conjugation of Budesonide. Novel Mechanism for Prolonged Retention of Topically Applied Steroid in Airway Tissue. Drug Metab. Dispos. 1998, 26, 623-630. [PubMed]

14. Wang, P.; Wang, X.; Yang, X.; Liu, Z.; Wu, M.; Li, G. Budesonide Suppresses Pulmonary Antibacterial Host Defense by DownRegulating Cathelicidin-Related Antimicrobial Peptide in Allergic Inflammation Mice and in Lung Epithelial Cells. BMC Immunol. 2013, 14, 7. [CrossRef]

15. Kuo, C.C.; Jackson, L.A.; Campbell, L.A.; Grayston, J.T. Chlamydia Pneumoniae (TWAR). Clin. Microbiol. Rev. 1995, 8, $451-461$. [CrossRef] [PubMed]

16. Carr, T.F.; Kraft, M. Chronic Infection and Severe Asthma. Immunol. Allergy Clin. N. Am. 2016, 36, 483-502. [CrossRef] [PubMed]

17. Paróczai, D.; Mosolygó, T.; Kókai, D.; Endrész, V.; Virok, D.P.; Somfay, A.; Burián, K. Chlamydia Pneumoniae Influence on Cytokine Production in Steroid-Resistant and Steroid-Sensitive Asthmatics. Pathogens 2020, 9. [CrossRef] [PubMed]

18. Eszik, I.; Lantos, I.; Önder, K.; Somogyvári, F.; Burián, K.; Endrész, V.; Virok, D.P. High Dynamic Range Detection of Chlamydia Trachomatis Growth by Direct Quantitative PCR of the Infected Cells. J. Microbiol. Methods 2016, 120, 15-22. [CrossRef] [PubMed] 
19. Virok, D.P.; Raffai, T.; Kókai, D.; Paróczai, D.; Bogdanov, A.; Veres, G.; Vécsei, L.; Poliska, S.; Tiszlavicz, L.; Somogyvári, F.; et al. Indoleamine 2,3-Dioxygenase Activity in Chlamydia Muridarum and Chlamydia Pneumoniae Infected Mouse Lung Tissues. Front. Cell Infect. Microbiol. 2019, 9, 192. [CrossRef]

20. Marcellini, A.; Swieboda, D.; Guedán, A.; Farrow, S.N.; Casolari, P.; Contoli, M.; Johnston, S.L.; Papi, A.; Solari, R. Glucocorticoids Impair Type I IFN Signalling and Enhance Rhinovirus Replication. Eur. J. Pharmacol. 2020, 893, 173839. [CrossRef]

21. Baeke, F.; Takiishi, T.; Korf, H.; Gysemans, C.; Mathieu, C. Vitamin D: Modulator of the Immune System. Curr. Opin. Pharmacol. 2010, 10, 482-496. [CrossRef]

22. Nelson, D.E.; Virok, D.P.; Wood, H.; Roshick, C.; Johnson, R.M.; Whitmire, W.M.; Crane, D.D.; Steele-Mortimer, O.; Kari, L.; McClarty, G.; et al. Chlamydial IFN-Gamma Immune Evasion Is Linked to Host Infection Tropism. Proc. Natl. Acad. Sci. USA 2005, 102, 10658-10663. [CrossRef] [PubMed]

23. Mosolygó, T.; Korcsik, J.; Balogh, E.P.; Faludi, I.; Virók, D.P.; Endrész, V.; Burián, K. Chlamydophila Pneumoniae Re-Infection Triggers the Production of IL-17A and IL-17E, Important Regulators of Airway Inflammation. Inflamm. Res. 2013, 62, 451-460. [CrossRef]

24. Yeh, J.-J.; Lin, C.-L.; Kao, C.-H. Associations among Chronic Obstructive Pulmonary Disease with Asthma, Pneumonia, and Corticosteroid Use in the General Population. PLoS ONE 2020, 15, e229484. [CrossRef] [PubMed]

25. Kim, M.H.; Rhee, C.K.; Shim, J.S.; Park, S.Y.; Yoo, K.H.; Kim, B.Y.; Bae, H.W.; Sim, Y.S.; Chang, J.H.; Cho, Y.J.; et al. Inhaled Corticosteroids in Asthma and the Risk of Pneumonia. Allergy Asthma Immunol. Res. 2019, 11, 795-805. [CrossRef] [PubMed]

26. Heijink, I.H.; Jonker, M.R.; de Vries, M.; van Oosterhout, A.J.M.; Telenga, E.; Ten Hacken, N.H.T.; Postma, D.S.; van den Berge, M. Budesonide and Fluticasone Propionate Differentially Affect the Airway Epithelial Barrier. Respir. Res. 2016, 17, 2. [CrossRef] [PubMed]

27. Kim, S.-R.; Song, J.-H.; Ahn, J.-H.; Lee, G.-S.; Ahn, H.; Yoon, S.-I.; Kang, S.G.; Kim, P.-H.; Jeon, S.-M.; Choi, E.-J.; et al. Antiviral and Anti-Inflammatory Activity of Budesonide against Human Rhinovirus Infection Mediated via Autophagy Activation. Antivir. Res. 2018, 151, 87-96. [CrossRef]

28. Leigh, R.; Mostafa, M.M.; King, E.M.; Rider, C.F.; Shah, S.; Dumonceaux, C.; Traves, S.L.; McWhae, A.; Kolisnik, T.; Kooi, C.; et al. An Inhaled Dose of Budesonide Induces Genes Involved in Transcription and Signaling in the Human Airways: Enhancement of Anti- and Proinflammatory Effector Genes. Pharmacol. Res. Perspect. 2016, 4. [CrossRef] [PubMed]

29. Umland, S.P.; Nahrebne, D.K.; Razac, S.; Beavis, A.; Pennline, K.J.; Egan, R.W.; Billah, M.M. The Inhibitory Effects of Topically Active Glucocorticoids on IL-4, IL-5, and Interferon-Gamma Production by Cultured Primary CD4+ T Cells. J. Allergy Clin. Immunol. 1997, 100, 511-519. [CrossRef]

30. Smith-Norowitz, T.A.; Loeffler, J.; Huang, Y.; Klein, E.; Norowitz, Y.M.; Hammerschlag, M.R.; Joks, R.; Kohlhoff, S. Chlamydia Pneumoniae Immunoglobulin E Antibody Levels in Patients with Asthma Compared with Non-Asthma. Heliyon 2020, 6. [CrossRef] [PubMed]

31. Smith-Norowitz, T.A.; Chotikanatis, K.; Weaver, D.; Ditkowsky, J.; Norowitz, Y.M.; Hammerschlag, M.R.; Joks, R.; Kohlhoff, S. Chlamydia Pneumoniae-Induced Tumour Necrosis Factor Alpha Responses Are Lower in Children with Asthma Compared with Non-Asthma. BMJ Open Respir. Res. 2018, 5, e000239. [CrossRef] [PubMed]

32. Black, P.N.; Scicchitano, R.; Jenkins, C.R.; Blasi, F.; Allegra, L.; Wlodarczyk, J.; Cooper, B.C. Serological Evidence of Infection with Chlamydia Pneumoniae Is Related to the Severity of Asthma. Eur. Respir. J. 2000, 15, 254-259. [CrossRef] [PubMed]

33. Byrne, G.I.; Lehmann, L.K.; Landry, G.J. Induction of Tryptophan Catabolism Is the Mechanism for Gamma-Interferon-Mediated Inhibition of Intracellular Chlamydia Psittaci Replication in T24 Cells. Infect. Immun. 1986, 53, 347-351. [CrossRef] [PubMed]

34. Burian, K.; Endresz, V.; Deak, J.; Kormanyos, Z.; Pal, A.; Nelson, D.; Virok, D.P. Transcriptome Analysis Indicates an Enhanced Activation of Adaptive and Innate Immunity by Chlamydia-Infected Murine Epithelial Cells Treated with Interferon $\gamma$. J. Infect. Dis. 2010, 202, 1405-1414. [CrossRef]

35. Balogh, E.P.; Faludi, I.; Virók, D.P.; Endrész, V.; Burián, K. Chlamydophila Pneumoniae Induces Production of the Defensin-like MIG/CXCL9, Which Has in Vitro Antichlamydial Activity. Int. J. Med. Microbiol. 2011, 301, 252-259. [CrossRef] [PubMed]

36. Davies, J.M.; Carroll, M.L.; Li, H.; Poh, A.M.; Kirkegard, D.; Towers, M.; Upham, J.W. Budesonide and Formoterol Reduce Early Innate Anti-Viral Immune Responses in Vitro. PLoS ONE 2011, 6, e27898. [CrossRef] [PubMed]

37. Dora, D.; Rivard, C.; Yu, H.; Bunn, P.; Suda, K.; Ren, S.; Lueke Pickard, S.; Laszlo, V.; Harko, T.; Megyesfalvi, Z.; et al. Neuroendocrine Subtypes of Small Cell Lung Cancer Differ in Terms of Immune Microenvironment and Checkpoint Molecule Distribution. Mol. Oncol. 2020, 14, 1947-1965. [CrossRef]

38. Maneechotesuwan, K.; Supawita, S.; Kasetsinsombat, K.; Wongkajornsilp, A.; Barnes, P.J. Sputum Indoleamine-2, 3-Dioxygenase Activity Is Increased in Asthmatic Airways by Using Inhaled Corticosteroids. J. Allergy Clin. Immunol. 2008, 121, 43-50. [CrossRef]

39. Feng, E.; Wan, R.; Yang, S.; Yan, Z.; Wang, S.; He, W.; Zhang, Y.; Yin, H.; Chen, Z.; Liu, R. Expression Levels of Induced Sputum IL-8 and IL-10 and Drug Intervention Effects in Patients with Acute Exacerbated COPD Complicated with Chronic Cor Pulmonale at High Altitude. Exp. Ther. Med. 2013, 6, 747-752. [CrossRef]

40. Li, H.-T.; Lin, Y.-S.; Ye, Q.-M.; Yang, X.-N.; Zou, X.-L.; Yang, H.-L.; Zhang, T.-T. Airway Inflammation and Remodeling of Cigarette Smoking Exposure Ovalbumin-Induced Asthma Is Alleviated by CpG Oligodeoxynucleotides via Affecting Dendritic Cell-Mediated Th17 Polarization. Int. Immunopharmacol. 2020, 82, 106361. [CrossRef] 
41. Honda, K.; Wada, H.; Nakamura, M.; Nakamoto, K.; Inui, T.; Sada, M.; Koide, T.; Takata, S.; Yokoyama, T.; Saraya, T.; et al. IL-17A Synergistically Stimulates TNF- $\alpha$-Induced IL-8 Production in Human Airway Epithelial Cells: A Potential Role in Amplifying Airway Inflammation. Exp. Lung Res. 2016, 42, 205-216. [CrossRef] [PubMed]

42. Zhang, Y.; Wang, H.; Ren, J.; Tang, X.; Jing, Y.; Xing, D.; Zhao, G.; Yao, Z.; Yang, X.; Bai, H. IL-17A Synergizes with IFN- $\gamma$ to Upregulate INOS and NO Production and Inhibit Chlamydial Growth. PLoS ONE 2012, 7, e39214. [CrossRef] [PubMed]

43. He, Q.; Ananaba, G.A.; Patrickson, J.; Pitts, S.; Yi, Y.; Yan, F.; Eko, F.O.; Lyn, D.; Black, C.M.; Igietseme, J.U.; et al. Chlamydial Infection in Vitamin D Receptor Knockout Mice Is More Intense and Prolonged than in Wild-Type Mice. J. Steroid Biochem. Mol. Biol. 2013, 135, 7-14. [CrossRef] [PubMed]

44. Youssef, D.A.; Miller, C.W.; El-Abbassi, A.M.; Cutchins, D.C.; Cutchins, C.; Grant, W.B.; Peiris, A.N. Antimicrobial Implications of Vitamin D. Dermatoendocrinology 2011, 3, 220-229. [CrossRef]

45. Qiu, S.-L.; Kuang, L.-J.; Tang, Q.-Y.; Duan, M.-C.; Bai, J.; He, Z.-Y.; Zhang, J.-Q.; Li, M.-H.; Deng, J.-M.; Liu, G.-N.; et al. Enhanced Activation of Circulating Plasmacytoid Dendritic Cells in Patients with Chronic Obstructive Pulmonary Disease and Experimental Smoking-Induced Emphysema. Clin. Immunol. 2018, 195, 107-118. [CrossRef]

46. Theegarten, D.; Anhenn, O.; Hotzel, H.; Wagner, M.; Marra, A.; Stamatis, G.; Mogilevski, G.; Sachse, K. A Comparative Ultrastructural and Molecular Biological Study on Chlamydia Psittaci Infection in Alpha-1 Antitrypsin Deficiency and NonAlpha-1 Antitrypsin Deficiency Emphysema versus Lung Tissue of Patients with Hamartochondroma. BMC Infect. Dis $2004,4,38$. [CrossRef]

47. Virók, D.P.; Eszik, I.; Mosolygó, T.; Önder, K.; Endrész, V.; Burián, K. A Direct Quantitative PCR-Based Measurement of Herpes Simplex Virus Susceptibility to Antiviral Drugs and Neutralizing Antibodies. J. Virol. Methods 2017, 242, 46-52. [CrossRef]

48. Burián, K.; Hegyesi, H.; Buzás, E.; Endrész, V.; Kis, Z.; Falus, A.; Gönczöl, E. Chlamydophila (Chlamydia) Pneumoniae Induces Histidine Decarboxylase Production in the Mouse Lung. Immunol. Lett. 2003, 89, 229-236. [CrossRef]

49. Zuśka-Prot, M.; Maślanka, T. Effect of Inhaled and Systemic Glucocorticoid Treatment on CD4+ Regulatory and Effector T Cells in a Mouse Model of Allergic Asthma. Int. Immunopharmacol. 2017, 45, 98-109. [CrossRef]

50. Becker, A.B.; Abrams, E.M. Asthma Guidelines: The Global Initiative for Asthma in Relation to National Guidelines. Curr. Opin. Allergy Clin. Immunol. 2017, 17, 99-103. [CrossRef] 


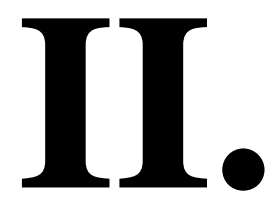


Article

\title{
Chlamydia pneumoniae Influence on Cytokine Production in Steroid-Resistant and Steroid-Sensitive Asthmatics
}

\author{
Dóra Paróczai, ${ }^{1,2}$, Tímea Mosolygó ${ }^{1}$, Dávid Kókai ${ }^{1}$, Valéria Endrész ${ }^{1}$, Dezső P. Virok ${ }^{1}$, \\ Attila Somfay ${ }^{2}$ and Katalin Burián 1,* \\ 1 Department of Medical Microbiology and Immunobiology, University of Szeged, Dóm sqr. 10., \\ 6720 Szeged, Hungary; paroczai.dora@med.u-szeged.hu (D.P.), mosolygo.timea@med.u-szeged.hu (T.M.), \\ kokai.david@med.u-szeged.hu (D.K.), endresz.valeria@med.u-szeged.hu (V.E.), \\ virok.dezso.peter@med.u-szeged.hu (D.P.V) \\ 2 Department of Pulmonology, University of Szeged, Alkotmány str.36., 6772 Deszk, Hungary; \\ paroczai.dora@med.u-szeged.hu (D.P.), somfay.attila@med.u-szeged.hu (A.S.) \\ * Correspondence: burian.katalin@med.u-szeged.hu
}

Received: 1 January 2020; Accepted: 8 February 2020; Published: 11 February 2020

\begin{abstract}
Medications for asthma management consisting of inhaled corticosteroids act by controlling symptoms. However, some patients do not respond to steroid treatment due to immunological factors at the cytokine level. Chlamydia pneumoniae (C. pneumoniae) infection is strongly implicated in asthma pathogenesis, causing altered immune responses. We investigated the association of $C$. pneumoniae serostatus with the production of certain cytokines by peripheral blood mononuclear cells (PBMCs) of steroid-resistant and -sensitive asthmatic patients. Our most important findings are the following: In the case of $C$. pneumoniae seropositive patients we detected pronounced spontaneous interleukin (IL)-10 secretion and, in the case of steroid-resistant patients, IL-10 secretion was at a significantly higher level as compared with in-sensitive patients $(p<0.01)$. Furthermore, steroid-resistant seropositive patients produced a significantly higher level of IL-10 spontaneously and under antigen stimulation as compared with steroid-resistant seronegative individuals $(p<0.05)$. Concerning spontaneous TNF- $\alpha$ secretion by C. pneumoniae seropositive asthmatics, we observed that steroid-resistant patients produced significantly more of this cytokine than steroid-sensitive patients. In the steroid-resistant patients' sera, a remarkably high MMP-9 concentration was associated with $C$. pneumoniae seronegativity. Our study revealed that the differences in the cytokine production in steroid-sensitive and -resistant asthmatic patients can be influenced by their C. pneumoniae serostatus.
\end{abstract}

Keywords: C. pneumonia; cytokine; asthma; steroid-resistant; infection

\section{Introduction}

Asthma is a chronic airway disease associated with airway remodeling, reversible bronchial obstruction, and airway hyperresponsiveness (AHR), and $1 \%$ to $18 \%$ of the global population are affected. Approximately $5 \%$ to $10 \%$ of asthmatic patients fail to fully respond to steroid therapy, and these patients also have higher mortality and morbidity rates [1]. A diagnosis of steroid resistance is made when patients exhibit $<15 \%$ improvement in the forced expiratory volume in one second (FEV1) during post-bronchodilator spirometry after 14 days of oral prednisolone therapy. Steroid resistance was first recognized in 1968 and several studies have since been performed in order to expand our understanding of the complex mechanisms resulting in steroid insensitivity [2]. Currently, there is 
an emerging clinical need to identify the factors contributing to the disease pathogenesis, as severely steroid-resistant asthmatic patients do not respond well to conventional therapies. A variety of factors such as infections and air pollution cause changes in cytokine production at the transcriptional and protein level, leading to steroid resistance [3-5]. Several studies have confirmed that infections, particularly early-life respiratory infections, are implicated in the pathogenesis of steroid-resistant asthma [6-8].

Chlamydia pneumoniae (C. pneumoniae) causes community-acquired pneumonia and accounts for airway remodeling in chronic lung diseases [9]. Asthmatics with earlier C. pneumoniae infection are more likely to develop steroid-resistant asthma, and their positive serostatus is associated with an increased severity of asthma and airway neutrophilia [10,11].

Interleukin (IL)-10 is an anti-inflammatory cytokine produced by regulatory $\mathrm{T}$ cells, macrophages, and even dendritic cells. It plays a crucial role in maintaining lung immune responses and participates in asthma pathogenesis by regulating and inhibiting Th2 responses. Asthmatic patients exhibit diminished IL-10 production in bronchoalveolar lavage (BAL) fluids and, to the best of our knowledge, there are no congruent data about the IL-10 production by the peripheral blood cells of these patients. In addition, IL-10 secretion by circulating cells has not been investigated in relation to the use of inhaled corticosteroids $[12,13]$. We hypothesized that a previous C. pneumoniae infection can change cytokine pattern and have an impact on subsequent IL-10 production with or without specific antigen stimulation of cells from steroid resistant asthmatics. IL-10 regulates responses of immune and airway cells that are infected by C. pneumoniae. A former, persistent infection can affect cytokine production through enhancing Toll-like receptor (TLR) signaling and nucleotide-binding oligomerization domain-like receptor family, pyrin domain-containing 3 (NLRP3) activity. TLR2, 4 signaling, and NLRP3 activity have a connection with glucocorticoid resistance mechanisms, including changes in glucocorticoid receptor (GR) expressions and altered cytokine secretion $[14,15]$. To the best of our knowledge, there are no data about the differences in cytokine production between asthmatics related to Chlamydia serostatus. Consequently, we hypothesized that determining IL-10 responses in steroid-resistant and -sensitive asthmatics proves that a former infection induces alterations in a different manner in asthma phenotypes.

Tumor necrosis factor alpha (TNF- $\alpha$ ) responses play a significant role in AHR via eosinophil and neutrophil attraction, nuclear factor kappa B (NF- $\kappa \mathrm{B})$ activation, production of adhesion molecules, and even myocyte proliferation [16]. All of these factors, along with immune and cytokine responses, can lead to the modification of GRs and changes in receptor affinity and binding capacity, resulting in reduced steroid responsiveness and a decline in lung function [17]. C. pneumoniae is able to induce TNF- $\alpha$ production and trigger cellular proliferation, leading to decreased steroid responsiveness of peripheral blood mononuclear cells (PBMCs) [18]. A previous C. pneumoniae infection could have a long-term effect on TNF- $\alpha$ response, hence, we investigated TNF- $\alpha$ secretion by PBMCs of Chlamydiaspecific $\operatorname{IgG}$ negative and positive patients.

Matrix metalloproteinases (MMPs) and their inhibitors are involved in the changes of the extracellular matrix and determine airway epithelium thickness. MMP-9 has a pivotal role in remodeling and was the first to be investigated in asthma. Elevated MMP levels, particularly MMP9, are detected in the BAL fluids and even in the sera of asthmatic patients $[19,20]$. Rödel et al. found increased MMP-1 and -3 production due to C. pneumoniae infection in smooth muscle cells [21]. C. pneumoniae affects MMP-9 and tissue inhibitor of metalloproteinase-1 (TIMP-1) production by PBMCs and weakens the impact of glucocorticoids on the secretion of MMPs [22]. The levels of MMP-9 inhibitor, TIMP-1, can be altered in asthmatics, however, the relationship with infections are not well studied. As corticosteroids do not normalize the elevated MMP-9 levels [23], we hypothesized that C. pneumoniae infection has a long-term effect in asthmatics and can lead to differences in MMP-9 level between steroid-resistant and -sensitive patients. There are no data regarding this association. MMP-9 seemed to be differentially released in exhaled condensates from asthmatics and based on this phenomenon, we can determine different biological phenotypes of asthma that can help to monitor diseases severity [24]. On the basis of the above-mentioned results, our aim was to compare 
MMP-9 levels in steroid-resistant and -sensitive asthmatic patients' sera which could contribute to a better understanding of steroid-resistant asthma features.

Taken together, IL-10 and TNF- $\alpha$ cytokine production by PBMCs of steroid-sensitive and resistant asthmatic patients have not been analyzed without and with antigen stimulation in relation to their C. pneumoniae serostatus. As C. pneumoniae is involved in asthma exacerbation, as well as in persistent infections, it can have a momentous impact on the cytokine production in asthmatic patients. The long-term effects of chronic C. pneumoniae infection on cytokine production in patients with asthma remain unclear. MMP-9 is implicated in the remodeling process of the lung and is believed to be influenced by C. pneumoniae infection. As there are no data available regarding MMP9 levels in steroid-sensitive and -resistant asthmatics, we intended to define differences in the patients' sera according to the C. pneumoniae serostatus and steroid responsiveness. The primary aim of this research was to find differences in steroid-resistant and -sensitive patients related to $C$. pneumoniae serostatus.

\section{Results}

\subsection{Patient Characteristics and Demographics}

In this study, 40 steroid-sensitive asthmatic patients (65\% female, $35 \%$ male, with a mean age of 59 years) and 40 steroid-resistant asthmatic patients (68\% female, 32\% male, with a mean age of 63 years) were enrolled. Steroid resistance was defined by the following criterion: Patients did not achieve $>15 \%$ improvement in the FEV1 value after 14 days of oral prednisolone (40 mg/day) therapy. In accordance with our expectations, the steroid-resistant group exhibited significant differences in dynamic lung volumes (Table 1). The steroid-resistant group had a mean FEV1 value of $56 \% \pm 0.2 \%$, with a significant difference as compared with the sensitive group with a mean FEV1 value of $72 \% \pm$ $0.22 \%$ ( $p=0.01$ ). The ICSs used were budesonide/formoterol dry powder inhaler (daily doses ranging from 400 to $1280 \mu \mathrm{g}$ ), cyclesonide hydrofluoroalkane (HFA) (daily doses ranging from 320 to $640 \mu \mathrm{g}$ ), fluticasone propionate/salmeterol HFA (daily doses ranging from 500 to $1000 \mu \mathrm{g}$ ), and beclomethasone dipropionate/formoterol HFA (daily doses ranging from 400 to $1000 \mu \mathrm{g}$ ). In the sensitive group, $50 \%$ of patients received high daily ICS doses, while in the resistant group, 95\% of patients used high dose ICS. Steroid doses were determined according to the GINA guideline [1]. Further clinical characteristics of asthmatic patients are provided in Table 1. As controls, 40 nonasthmatic, healthy blood donors were selected.

Table 1. Main clinical characteristics and demographic data of the steroid sensitive and steroidresistant patients.

\begin{tabular}{|c|c|c|c|}
\hline & $\begin{array}{c}\text { Steroid-sensitive } \\
\mathrm{n}=40\end{array}$ & $\begin{array}{l}\text { Steroid-resistant } \\
\mathrm{n}=40\end{array}$ & $\begin{array}{c}p \\
\text { value }\end{array}$ \\
\hline Mean age (median) & $59(63)$ & $63(67)$ & 0.13 \\
\hline Gender & $\begin{array}{l}\text { male: } 14(35 \%), \\
\text { female: } 26(65 \%)\end{array}$ & $\begin{array}{l}\text { male: } 13(32 \%) \\
\text { female: } 27(68 \%)\end{array}$ & - \\
\hline Smoking, mean py & $\mathrm{n}=15(24,5)$ & $\mathrm{n}=19(31)$ & 0.14 \\
\hline Smoking status & $\begin{array}{c}\text { Never: } 25 \\
\text { Previously: } 7 \\
\text { Habitual: } 8 \\
\end{array}$ & $\begin{array}{c}\text { Never: } 21 \\
\text { Previously: } 10 \\
\text { Habitual: } 9\end{array}$ & \\
\hline $\begin{array}{c}\text { Atopic subjects (allergic rhinitis, sinusitis, } \\
\text { nasal polyposis) }\end{array}$ & $\mathrm{n}=22(55 \%)$ & $\mathrm{n}=25(63 \%)$ & - \\
\hline CHD & $\mathrm{n}=2(5 \%)$ & $\mathrm{n}=17(42 \%)$ & - \\
\hline Blood eosinophilia & $\mathrm{n}=11(27 \%)$ & $\mathrm{n}=17(42 \%)$ & 0.319 \\
\hline FEV1 $(\mathrm{L}, \%)$ & $2.1 \pm 0.8(72 \pm 0.2 \%)$ & $1.4 \pm 0.6(56 \pm 0.2 \%)$ & 0.01 \\
\hline FEV1 reversibility rate & $15.2 \pm 2.6$ & $12.6 \pm 3.3$ & 0.41 \\
\hline
\end{tabular}




\begin{tabular}{|c|c|c|c|}
\hline (mean, \%) & & & \\
\hline FVC $(L, \%)$ & $3.3 \pm 1.1(92.8 \pm 24 \%)$ & $2.5 \pm 0.9(79.9 \pm 21 \%)$ & 0.03 \\
\hline FEV1/FVC (\%) & $65.4 \pm 11.3 \%$ & $60.1 \pm 14.8 \%$ & 0.09 \\
\hline FEF25/75 (L/s) & $1.4 \pm 0.8$ & $0.8 \pm 0.4$ & 0.004 \\
\hline BMI $\left(\mathrm{kg} / \mathrm{m}^{2}\right)$ & $29.4 \pm 8.1$ & $27.6 \pm 5.1$ & 0.3 \\
\hline Asthma medications & $\begin{array}{l}\text { ICS: } 8 \text { patients } \\
\text { ICS/LABA: } 32 \\
\text { patients } \\
\text { SABA: } 28 \text { patients } \\
\text { LTI: } 20 \text { patients }\end{array}$ & $\begin{array}{c}\text { ICS/LABA: } 40 \\
\text { patients } \\
\text { LAMA: } 8 \text { patients } \\
\text { SABA: } 31 \text { patients } \\
\text { LTI: } 27 \text { patients }\end{array}$ & \\
\hline
\end{tabular}

BMI, body mass index; CHD, coronary heart disease; FEF 25/75, forced expiratory flow at $25 \%$ to $75 \%$ of the pulmonary volume; FEV1, forced expiratory volume in $1 \mathrm{~s}$; FVC, forced vital capacity; ICS; inhaled corticosteroid; LABA, long-acting $\beta$-agonist; LTI, leukotriene inhibitor; py, pack year; SABA; short-acting $\beta$-agonist.

\subsection{C. pneumoniae-Specific Serological Status of Asthmatic Patients}

First, we assayed the serum samples for the presence of $C$. pneumoniae-specific IgG to determine the seropositivity rate in each group. The control group representing the average Hungarian population exhibited a $67 \%$ seropositivity rate. Surprisingly, we observed a lower $C$. pneumoniae seropositivity rate in asthmatic patients than among the controls. In asthmatic patients, $42 \%$ of steroid-sensitive and $47 \%$ of steroid-resistant participants were C. pneumoniae IgG-positive (Figure 1).

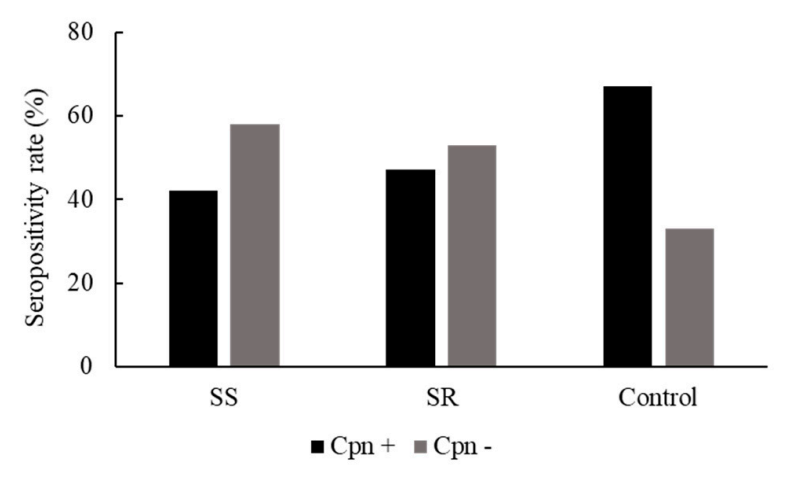

Figure 1. C. pneumoniae serostatus of healthy blood donors (controls) and patients with asthma.

C. pneumoniae serostatus was determined by an enzyme-linked immunosorbent assay from the native blood samples from controls and steroid-sensitive (SS) and steroid-resistant (SR) asthmatics (C. pneumoniae seropositive (Cpn+) and C. pneumoniae seronegative (Cpn-)).

\subsection{IL-10 Cytokine Production in Asthmatics in Response to Specific (C. pneumoniae) and Nonspecific phytohemagglutinin (PHA) Stimulation}

PBMCs obtained from steroid-resistant and -sensitive asthmatics were cultured with the $C$. pneumoniae antigen or phytohemagglutinin (PHA); or were untreated.

Untreated PBMCs from C. pneumoniae seropositive, steroid-sensitive patients secreted a significantly higher amount of IL-10 than did those from the C. pneumoniae positive non-asthmatic blood donors $(0.17 \pm 0.06 \mathrm{ng} / \mathrm{ml}$ versus $0.03 \pm 0.01 \mathrm{ng} / \mathrm{ml}, p=0.04)$. The same tendency was observed in the seropositive steroid-resistant group, as their PBMCs spontaneously produced a higher amount of IL-10 than did those of seropositive non-asthmatic blood donors $(0.41 \pm 0.07 \mathrm{ng} / \mathrm{ml}$ versus $0.03 \pm$ $0.01 \mathrm{ng} / \mathrm{ml}, p=0.0002$ ) (Figure 2A). 
Moreover, significantly higher IL-10 production was detected without stimulation in $C$. pneumoniae seropositive, steroid-resistant patients than in steroid-sensitive patients $(0.41 \pm 0.07 \mathrm{ng} / \mathrm{ml}$ vs. $0.17 \pm 0.06 \mathrm{ng} / \mathrm{ml}, p=0.002$ ) (Figure $2 \mathrm{~A}$ ).

Interestingly, when the PBMCs from C. pneumoniae seropositive individuals were cultured with C. pneumoniae antigen or PHA, no significant difference was observed between the asthmatic groups and the control group related to IL-10 production (Figure 2A).

Concerning steroid resistance, we compared IL-10 production in C. pneumoniae seropositive and seronegative asthmatics. We found that in cases of seropositivity, steroid-resistant patients exhibited significantly higher spontaneous IL-10 cytokine release than did seronegative individuals $(0.41 \pm 0.07$ $\mathrm{ng} / \mathrm{ml}$ vs. $0.25 \pm 0.14 \mathrm{ng} / \mathrm{ml}, p=0.02$ ). Moreover, after specific C. pneumoniae antigen stimulation, significantly higher IL-10 levels were found in the seropositive steroid-resistant group than in the seronegative steroid-resistant group $(0.59 \pm 0.18 \mathrm{ng} / \mathrm{ml}$ vs. $0.34 \pm 0.13 \mathrm{ng} / \mathrm{ml}, p=0.02)$. Regarding the cytokine response to nonspecific PHA stimulation, we observed no differences related to the $C$. pneumoniae serostatus among steroid-resistant asthmatics (Figure 2B).
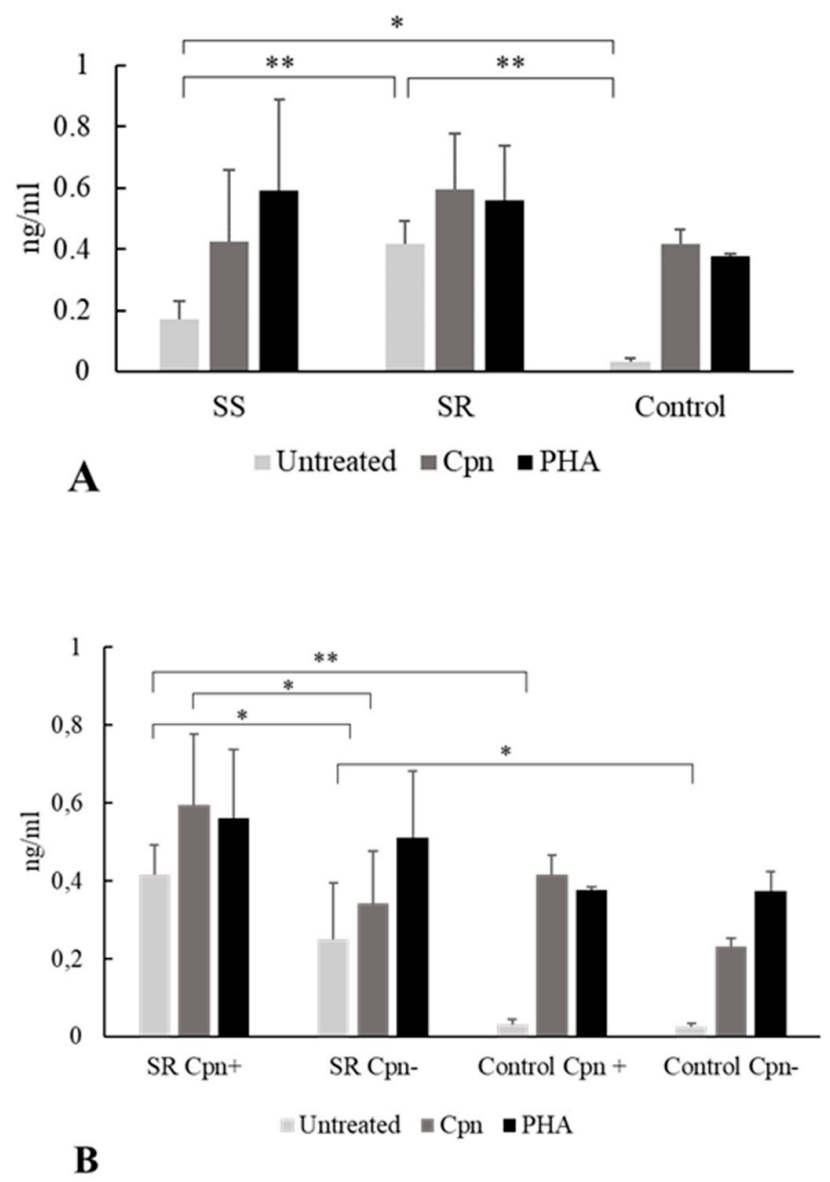

Figure 2. Effect of stimulation with C. pneumoniae and phytohemagglutinin (PHA) on interleukin (IL)10 secretion.

Human peripheral blood mononuclear cells (PBMCs) were obtained from steroid-resistant (SR) and steroid-sensitive (SS) asthma patients and healthy blood donors (controls) with C. pneumoniae seropositivity (Cpn+) and seronegativity (Cpn-) as follows:

(A) IL-10 concentrations were determined by enzyme-linked immunosorbent assay and expressed as $\mathrm{ng} / \mathrm{ml}$ (mean $\pm \mathrm{SD}$ ) in the C. pneumoniae seropositive groups. 
(B) IL-10 production by PBMCs of $C$. pneumoniae seropositive and seronegative SR patients as compared with controls (mean $\pm \mathrm{SD}$ ). Asterisks indicate significant differences $\left({ }^{*} p<0.05,{ }^{* *} p<0.01\right)$.

2.4. TNF- $\alpha$ Production in Asthmatics in Response to Specific (C. pneumoniae) and Nonspecific PHA Stimulation

PBMCs obtained from asthmatics and cultured without stimulation produced a higher amount of TNF- $\alpha$ than did those from non-asthmatics, however these differences did not reach significance. PBMCs from C. pneumoniae seropositive steroid-resistant participants spontaneously secreted a higher level of TNF- $\alpha$ than did seropositive steroid-sensitive patients $(0.23 \pm 0.16 \mathrm{ng} / \mathrm{ml} \mathrm{vs} .0 .08 \pm 0.06$ $\mathrm{ng} / \mathrm{ml}, p=0.05$ ) (Figure 3).

In response to specific and nonspecific treatments, in C. pneumoniae seropositive asthmatics there was no significant difference in the secreted TNF- $\alpha$ levels between the steroid-sensitive and -resistant groups.

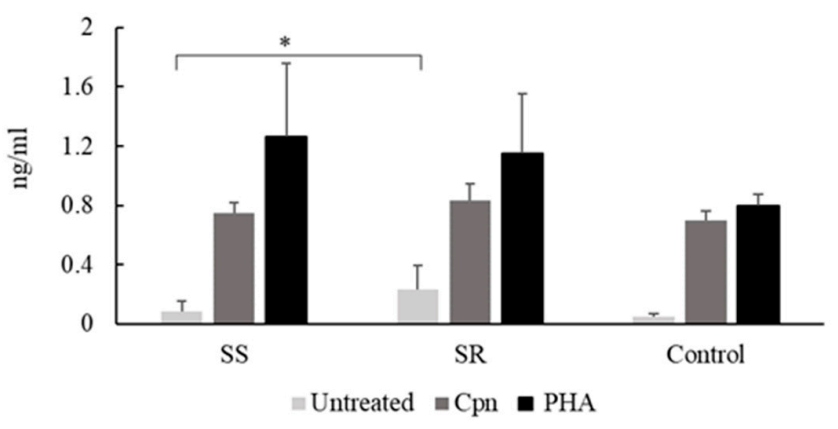

Figure 3. C. pneumoniae and PHA induced TNF- $\alpha$ production of PBMCs from seropositive control and asthmatic participants.

Tumor necrosis factor-alpha (TNF- $\alpha$ ) content of the supernatants of peripheral blood mononuclear cells (PBMCs) from seropositive steroid-sensitive (SS) and steroid-resistant (SR) asthmatic patients and healthy blood donors (controls). TNF- $\alpha$ concentrations were determined by enzyme-linked immunosorbent assay and expressed as $\mathrm{ng} / \mathrm{ml}$ (mean $\pm \mathrm{SD}$ ). Significant differences are labelled with asterisks, ${ }^{*} p<0.05$.

\subsection{MMP-9 Production in Steroid-Sensitive and Steroid-Resistant Asthmatic Patients}

The serum level of MMP-9 was measured in C. pneumoniae seropositive and seronegative steroid-sensitive and steroid-resistant asthmatics. A significant difference in the serum MMP-9 level was observed among the steroid-resistant participants. C. pneumoniae seronegative patients exhibited significantly increased serum levels of MMP-9 as compared with those found in C. pneumoniae seropositive asthmatics ( $p=0.01,1.46 \pm 1.124 \mathrm{ng} / \mathrm{ml}$ vs. $0.528 \pm 0.193 \mathrm{ng} / \mathrm{ml}$ ) However, this difference was not observed among steroid-sensitive patients. In association with C. pneumoniae seronegativity, a statistically significantly higher MMP-9 level was found in the sera of steroid-resistant patients than in steroid-sensitive patients $(1.46 \pm 1.125 \mathrm{ng} / \mathrm{ml}$ vs. $0.87 \pm 0.49 \mathrm{ng} / \mathrm{ml}, p=0.04)$ (Figure 4 ). 


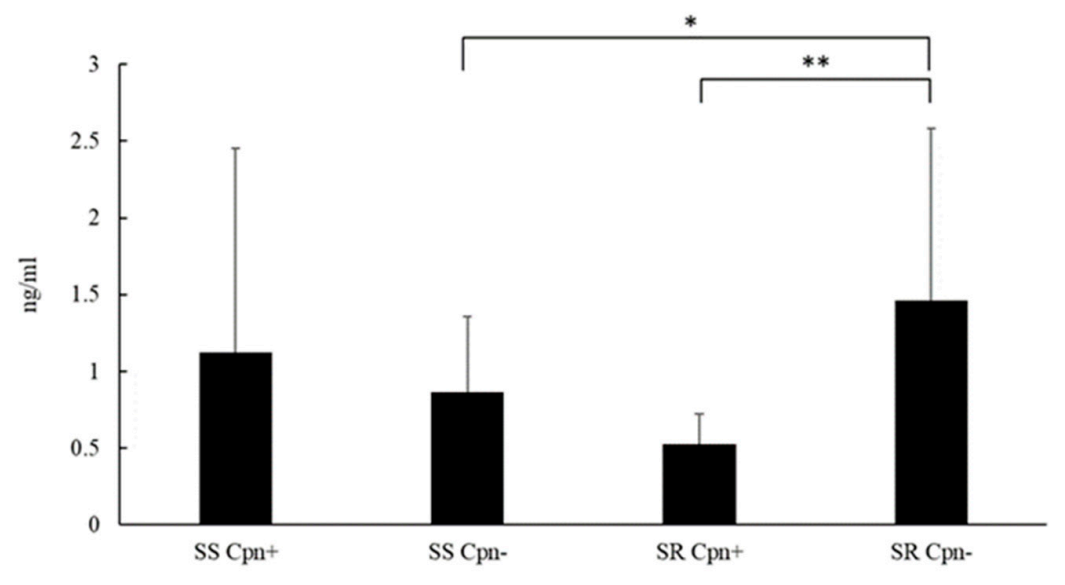

Figure 4. Serum matrix metalloproteinase (MMP)-9 levels in patients with asthma.

MMP-9 levels were measured in steroid-sensitive (SS) and steroid-resistant (SR) C. pneumoniae seropositive $(\mathrm{Cpn}+)$ and seronegative $(\mathrm{Cpn}-)$ asthmatic patients using an enzyme-linked immunosorbent assay. Data are expressed as $\mathrm{ng} / \mathrm{ml}$ (mean $\pm \mathrm{SD}$ ). Significant differences are labelled with asterisks, ${ }^{*} p<0.05$ and ${ }^{* *} p=0.01$

\section{Discussion}

Asthma is a heterogeneous, reversible, obstructive lung disease with systemic immunological features and variable phenotypes. In this study, we examined cytokine responses in asthmatic patents with different asthmatic phenotypes in relation to their steroid responsiveness and C. pneumoniae serological status. We aimed to determine whether steroid-resistant asthmatics and steroid-sensitive patients differ only in treatment responsiveness and clinical features, or in the cytokine response to the presence of specific antigens as well. Therefore, we investigated the in vitro IL-10 and TNF- $\alpha$ responses of $C$. pneumoniae seropositive and seronegative steroid-resistant and steroid-sensitive asthmatic patients' PBMCs to a polyclonal mitogen and C. pneumoniae antigen. Moreover, we examined MMP-9 blood serum levels in association with their C. pneumoniae serostatus to detect differences between steroid-resistant and -sensitive asthmatics.

We hypothesized that a prior C. pneumoniae infection has an impact on IL-10 production in asthmatic patients. We examined cytokine production under different stimuli in steroid-resistant and steroid-sensitive patients. Untreated PBMCs from C. pneumoniae seropositive patients secreted a higher level of IL-10 than did those from controls. These data correspond to the fact that higher serum IL-10 levels were observed in asthmatics than in controls [25]. Our results indicated that increased IL-10 responses are derived from PBMCs, indicating that in asthma pathogenesis, systemic immune responses can alter disease severity and clinical features.

In the C. pneumoniae seropositive groups, we detected greater spontaneous IL-10 secretion in steroid-resistant individuals than in steroid-sensitive individuals. Additionally, PBMCs from steroidresistant $C$. pneumoniae seropositive asthmatics produced significantly higher IL-10 responses when untreated and under C. pneumoniae stimulation, supporting the notion that earlier $C$. pneumoniae infection contributes to an altered IL-10 response in steroid-resistant asthmatics. In contrast, we did not observe a similar tendency in steroid-sensitive patients, reflecting the distinct immunological features in steroid-resistant participants.

In asthmatics, there is a positive correlation between disease severity and the IL-10 level. Accordingly, patients with asthma exhibit a higher IL-10 serum level than that of healthy individuals [26]. Glucocorticoids enhance IL-10 secretion and Treg functions, consequently, in steroid-resistant asthmatics, these effects cannot be observed clearly. However, it is well-known that IL-10 responses can be reversed and steroid responsiveness can be repaired in steroid-resistant asthmatics [27]. The precise role of IL-10 is unclear in asthma pathogenesis, particularly, in steroid-resistant asthmatics, 
and appears to be pleiotropic. One study revealed that under dexamethasone stimulation, CD4+ T cells from patients with steroid-resistant asthma failed to induce IL-10 synthesis [28]. To the best of our knowledge, IL-10 production by PBMCs from asthmatic patients under different stimuli have not been studied in relation to the C. pneumoniae serostatus and steroid responsiveness. Collectively, our data indicate that a previous $C$. pneumoniae infection can affect IL-10 secretion by PBMCs in asthmatics and raise further demand to analyze immune response differences between steroidsensitive and -resistant patients.

Related to the TNF- $\alpha$ response, in this study, we found only one significant difference in $C$. pneumoniae seropositive asthmatics. PBMCs from steroid-resistant patients spontaneously secreted significantly higher levels of TNF- $\alpha$ than did those of steroid-sensitive patients, however, under $C$. pneumoniae stimulation no significant differences were detected between healthy volunteers, steroidsensitive, and steroid resistant asthmatics. In contrast, pediatric patients with asthma have demonstrated a possibly altered ineffective Th1 immune response, resulting in lower TNF$\alpha$ responses from C. pneumoniae infected PBMCs [29]. Differences among adult asthmatics have also been demonstrated under specific circumstances such as pregnancy [30]. These findings point out the possibility of impaired cytokine responses under determined factors that can interfere with asthma pathogenesis and C. pneumoniae infection [31].

Undoubtedly, former studies have revealed that TNF- $\alpha$ plays a central role in the pathogenesis of refractory asthma, particularly, in the remodeling process and steroid responsiveness. A higher TNF- $\alpha$ level was observed in BAL fluid and in the peripheral blood in asthmatics as compared with healthy controls [32]. The TNF- $\alpha$ axis contributes to activation of NF- $\kappa B$, and therefore promotes proinflammatory cytokine expression. TNF- $\alpha$ induces the recruitment of eosinophil and neutrophil cells and plays a role in airway remodeling and decreased glucocorticoid response via cellular and immune responses [16,33]. C. pneumoniae is also involved in refractory asthma, as it alters the apoptosis process of infected cells and prolongs cell survival leading to airway structure changes. Cho et al. demonstrated that C. pneumoniae-infected PBMCs promoted cell proliferation in a Th2 microenvironment and $\mathrm{T}$ lymphocytes were resistant to the proapoptotic effect of glucocorticoids. These results were attributable to TNF- $\alpha$ axis activation and its modified function [18].

It is well-known that MMPs are involved in extracellular matrix changes and cytokine regulation. Moreover, MMP-9 levels correlate with lung function parameters, for example, FEV1 [34]. It is worth noting that pivotal differences in exhaled MMP-9 levels were detected in mild/moderate eosinophilic, severe eosinophilic, and severe neutrophilic asthmatics, indicating an association between asthma severity and airway remodeling [24].

The effect of corticosteroids on MMP-9 production is controversial. Inhaled steroids did not reduce the exhaled MMP-9 rate [34], and this trend was also observed in BAL fluids of steroid responder and non-responder patients with asthma [35]. A previous study revealed no difference between C. pneumoniae infected and uninfected PBMCs regarding MMP-9 production. However, $C$. pneumoniae infection increased TIMP-1 secretion, leading to a decreased MMP-9/TIMP-1 ratio. Moreover, dexamethasone treatment resulted in a further reduction of this ratio [22]. In this study, we measured the serum MMP-9 levels to define differences related to the C. pneumoniae-specific IgG serostatus and steroid responsiveness. Steroid-resistant C. pneumoniae seropositive patients had a lower MMP-9 level than did seronegative patients. In addition, C. pneumoniae seronegative steroidresistant patients had significantly higher MMP-9 levels than did steroid-sensitive individuals, indicating the probable intensified remodeling process. Former studies have revealed a strong association between MMP-9 expression and C. pneumoniae infection in atherosclerotic plaques; moreover, Paolillo et al. observed increased MMP-9 production in C. pneumoniae-infected human endothelial cells [36,37]. In addition, it is well-known that MMP-9 plays a detrimental role in the pathogenesis of allergic airway diseases [38,39]. Nevertheless, the punctual effect of C. pneumoniae on MMP-9 production in bronchial epithelial cells and alveolar macrophages remains unclear and further studies are needed to define the role of C. pneumoniae in MMP-9 secretion and lung fibrosis.

Taken together, our findings revealed unknown features of asthmatic patients and strengthened the line of evidence that former infection could affect asthma mechanisms. To the best of our 
knowledge, this is the first study that compared asthmatic patients on the basis of steroid responsiveness and C. pneumoniae seropositivity. In summary, we emphasize the following milestone results: (i) In steroid-sensitive C. pneumoniae positive patients a significant IL-10 production was observed as compared with control individuals; (ii) similar differences were found in spontaneous IL-10 secretion of PBMCs from seropositive steroid-resistant asthmatics; (iii) like resistant asthmatics, we found a significantly higher IL-10 production without treatment and under C. pneumoniae stimuli in seropositive patients as compared with seronegative individuals; (iv) additionally, this study raised that seropositive steroid-resistant asthmatics expressed a significantly higher level of spontaneous TNF- $\alpha$ than steroid-sensitive asthmatics; (v) significantly higher MMP-9 levels were found in steroid-resistant seronegative patients than seropositive patients; and (vi) the same trend was also seen as compared with seronegative steroid-sensitive participants.

\section{Materials and Methods}

\subsection{Study Population and Participants}

Eighty adult patients with asthma were recruited from the outpatient departments and inpatient wards at the Department of Pulmonology (University of Szeged, Hospital of Chest Diseases, Deszk). The inclusion criteria included clinically stable asthma, persistent asthma symptoms, inhaled steroid use, absence of current exacerbation, and complete follow-up periods. The exclusion criteria included a history of HIV infection, current viral or bacterial infections, chronic immunosuppression or autoimmune disease, cancer, systemic intravenous corticosteroid use (in the past 30 days), and antibiotic treatment (in the past 30 days). As a control group, 40 non-asthmatic, healthy blood donors without obstructive lung diseases, nasal polyposis, allergic rhinoconjunctivitis, cancer, chronic heart disease, autoimmune diseases, and immunosuppression were selected. Patients' demographic and clinical characteristics were recorded. To investigate cytokine production, $5 \mathrm{ml}$ native and $5 \mathrm{ml}$ unfractionated heparin anticoagulated blood samples were collected from each patient. Before collecting blood samples from the patients with asthma, post-bronchodilator tests were performed. After administering $400 \mu \mathrm{g}$ inhaled salbutamol, dynamic lung volumes (the FEV1, forced vital capacity [FVC], FEV1/FVC, and forced expiratory flow at $25 \%$ to $75 \%$ of the pulmonary volume [FEF25/75]) were measured. Spirometry was carried out using a Carefusion MasterScreen Body Plethysmograph (Sentrysuite software 2.13).

Asthmatic and control patients were not involved in the development, implementation, and interpretation of the study. Our study was undertaken in accordance with the Regional Human Biomedical Research Ethics Committee, University of Szeged (WHO-3220, 77/2013, 27/05/2013). Patients received written and verbal information about the purpose of blood sampling. All patients volunteered and their written informed consents were obtained.

\subsection{C. pneumoniae-Specific Enzyme-Linked Immunosorbent Assay}

C. pneumoniae-specific antibodies from the patients and the controls were detected using the "NovaLisa TM Chlamydia pneumoniae" enzyme-linked immunosorbent assay [ELISA] kit (Nova Tec Immundiagnostica GmbH, Germany). Fifty-fold diluted sera were tested in duplicate in accordance with the manufacturer's instructions for the presence of $C$. pneumoniae-specific immunoglobulin (Ig) G.

\subsection{Preparation of the C. pneumoniae Antigen}

C. pneumoniae CWL29 (ATCC, US) elementary bodies (EBs) were purified from infected Hep2 cells (ECACC, London, UK) by density gradient centrifugation and inactivated with formaldehyde treatment, as described by Penttila et al. [40]. The protein content of the antigen was measured by spectrophotometry, and the antigen was stored at $-80{ }^{\circ} \mathrm{C}$ until use. 


\subsection{Separation and Stimulation of PBMCs}

PBMCs from $10 \mathrm{ml}$ heparinized blood were separated using Ficoll gradient (Sigma), $5 \times 10^{5}$ cells in three parallel wells were incubated in the presence of $2 \mu \mathrm{g} / \mathrm{ml} \mathrm{C}$. pneumoniae antigen or $10 \mu \mathrm{g} / \mathrm{ml}$ polyclonal mitogen (phytohemagglutinin, PHA) or left untreated in $200 \mu \mathrm{l}$ RPMI medium containing $10 \%$ fetal bovine serum supplemented with glutamine, non-essential amino acids, gentamycin, and fluconazole. Supernatants of the stimulated wells were harvested $48 \mathrm{~h}$ after treatment, aliquoted, and stored at $-80{ }^{\circ} \mathrm{C}$ until performing the cytokine ELISA.

\subsection{Cytokine ELISA}

The supernatants of the stimulated or untreated PBMCs were centrifuged ( $5 \mathrm{~min}, 1200 \mathrm{rpm}$ ) and assayed for the concentrations of IL-10 and TNF- $\alpha$ using Human Mini ELISA Development cytokine kits (PeproTech), while the quantity of MMP-9 in the sera was determined using the human MMP-9 ELISA kit (Sigma). The sensitivities of the IL-10, TNF- $\alpha$, and MMP-9 measurements were in the range of 23 to 3000, 16 to 2000, and 8.23 to $6000 \mathrm{pg} / \mathrm{ml}$, respectively. The clarified supernatants and sera were tested in duplicate in accordance with the manufacturer's instructions.

\subsection{Statistical Analysis}

Statistical analysis of the data was carried out using SigmaPlot for Windows Version 11.0 software, using the Wilcoxon-Mann-Whitney two-sample test. Differences were considered statistically significant at $p<0.05$.

\section{Conclusions}

In summary, this study provides novel data about the different cytokine secretion of PBMCs from steroid-resistant and -sensitive asthmatic patients with or without stimulation. Our findings suggest that steroid resistance is associated with altered cytokine production based on Chlamydia pneumoniae serostatus. Our investigations support the heterogeneous features of asthma disease and contribute to define better steroid-resistant asthmatic characteristics at the cytokine level. Currently, there is increasing demand to use immunotherapy in asthma management based on the inhibition of Th2 cytokines or IgE [41,42]. Consequently, there is an emerging need to determine the immunological phenotypes of asthma, and therefore understand the pitfalls of conventional therapies. As our research was not without limitations, further studies are required to define the precise mechanisms underlying infection-mediated asthma and the long-term effect of persistent $C$. pneumoniae infection.

Author Contributions: D.P. designed the experiments, collected blood samples, implemented postbronchodilator spirometry, provided and analyzed clinical data, contributed to lab measurements and interpretation, prepared the manuscript; T.M., D.K., and V.E. were involved in performing C. pneumoniae specific ELISA, cytokine ELISA measurements and data analysis; D.P.V. and K.B. contributed to design the study, interpret lab data, prepare, and review manuscript; A.S. were involved in blood sampling, patient consent obtaining, and spirometry measurements, as well as interpreting clinical data. All authors have read and agreed to the published version of the manuscript.

Funding: K.B. and D.P.V. were supported by the Hungarian-European Union Grant EFOP-3.6.1-16-2016-00008.

Acknowledgments: D.P. was advocated by the Hungarian Respiratory Foundation with a postgraduate PhD scholarship.

Conflicts of Interest: The authors declare no conflict of interest.

\section{References}

1. 2018 GINA Report: Global Strategy for Asthma Management and Prevention/Global Initiative for Asthma-GINA. Available online: http://ginasthma.org/2018-gina-report-global-strategy-for-asthmamanagement-and-prevention/ (accessed on 9 June 2018). 
2. Schwartz, H.J.; Lowell, F.C.; Melby, J.C. Steroid resistance in bronchial asthma. Ann. Intern. Med. 1968, 69, 493-499.

3. Kim, R.Y.; Horvat, J.C.; Pinkerton, J.W.; Starkey, M.R.; Essilfie, A.T.; Mayall, J.R.; Nair, P.N.; Hansbro, N.H.; Jones, B.; Haw, T.J.; et al. MicroRNA-21 drives severe, steroid-insensitive experimental asthma by amplifying phosphoinositide 3-kinase-mediated suppression of histone deacetylase 2. J. Allergy Clin. Immunol. 2017, 139, 519-532, doi:10.1016/j.jaci.2016.04.038.

4. Li, L.-B.; Leung, D.Y.M.; Martin, R.J.; Goleva, E. Inhibition of histone deacetylase 2 expression by elevated glucocorticoid receptor beta in steroid-resistant asthma. Am. J. Respir. Crit. Care Med. 2010, 182, 877-883, doi:10.1164/rccm.201001-0015OC.

5. Hansbro, P.M.; Kim, R.Y.; Starkey, M.R.; Donovan, C.; Dua, K.; Mayall, J.R.; Liu, G.; Hansbro, N.H.; Simpson, J.L.; Wood, L.H.; et al. Mechanisms and treatments for severe, steroid-resistant allergic airway disease and asthma. Immunol. Rev. 2017, 278, 41-62, doi:10.1111/imr.12543.

6. Horvat, J.C.; Starkey, M.R.; Kim, R.Y.; Phipps, S.; Gibson, P.G.; Beagley, K.W.; Foster, P.S.; Hansbro, P.M. Early-life chlamydial lung infection enhances allergic airways disease through age-dependent differences in immunopathology. J. Allergy Clin. Immunol. 2010, 125, 617-625, doi:10.1016/j.jaci.2009.10.018.

7. Hansbro, P.M.; Starkey, M.R.; Mattes, J.; Horvat, J.C. Pulmonary immunity during respiratory infections in early life and the development of severe asthma. Ann. Am. Thorac. Soc. 2014, 11 (Suppl. 5), S297-S302, doi:10.1513/AnnalsATS.201402-086AW.

8. Starkey, M.R.; Nguyen, D.H.; Kim, R.Y.; Nair, P.M.; Brown, A.C.; Essifie, A.T.; Horvat, J.C.; Hansbro, P.M. Programming of the lung in early life by bacterial infections predisposes to chronic respiratory disease. Clin. Obstet. Gynecol. 2013, 56, 566-576, doi:10.1097/GRF.0b013e3182993a0c.

9. Grayston, J.T.; Campbell, L.A.; Kuo, C.C.; Mordhorst, C.H.; Saikku, P.; Thorn, D.H.; Wang, S.P. A new respiratory tract pathogen: Chlamydia pneumoniae strain TWAR. J. Infect. Dis. 1990, 161, 618-625.

10. Patel, K.K.; Vicencio, A.G.; Du, Z.; Tsirilakis, K.; Salva, P.S.; Webley, W.C. Infectious Chlamydia pneumoniae is associated with elevated interleukin-8 and airway neutrophilia in children with refractory asthma. Pediatric Infect. Dis. J. 2010, 29, 1093-1098.

11. Black, P.N.; Scicchitano, R.; Jenkins, C.R.; Blasi, F.; Allegra, L.; Wlodarczyk, J.; Cooper B;C. Serological evidence of infection with Chlamydia pneumoniae is related to the severity of asthma. Eur. Respir. J. 2000, 15, 254-259.

12. Borish, L.; Aarons, A.; Rumbyrt, J.; Cvietusa, P.; Negri, J.; Wenzel, S. Interleukin-10 regulation in normal subjects and patients with asthma. J. Allergy Clin. Immunol. 1996, 97, 1288-1296.

13. Matsumoto, K.; Inoue, H.; Fukuyama, S.; Tsuda, M.; Ikegami, T.; Kibe, A.; Yoshiura, Y.; Komori, M.; Hamasaki, N.; Aizawa, H.; et al. Decrease of interleukin-10-producing T cells in the peripheral blood of severe unstable atopic asthmatics. Int. Arch. Allergy Immunol. 2004, 134, 295-302, doi:10.1159/000079167.

14. Kim, R.Y.; Pinkerton, J.W.; Essilfie, A.T.; Robertson, A.A.B.; Baines, K.J.; Brown, A.C.; Mayall, J.R.; Ali, M.K.; Starkey, M.R.; Hansbro, N.G.; et al. Role for NLRP3 Inflammasome-mediated, IL-1 $\beta$-Dependent Responses in Severe, Steroid-Resistant Asthma. Am. J. Respir. Crit. Care Med. 2017, 196, 283-297, doi:10.1164/rccm.201609-1830OC.

15. Rahman, M.M.; Prabhala, P.; Rumzhum, N.N.; Patel, B.S.; Wickop, T.; Hansbro, P.M.; Verrills, N.M.; Ammit, A.J. TLR2 ligation induces corticosteroid insensitivity in A549 lung epithelial cells: Antiinflammatory impact of PP2A activators. Int. J. Biochem. Cell Biol. 2016, 78, 279-287, doi:10.1016/j.biocel.2016.07.030.

16. Berry, M.; Brightling, C.; Pavord, I.; Wardlaw, A. TNF-alpha in asthma. Curr. Opin. Pharmacol. 2007, 7, 279282, doi:10.1016/j.coph.2007.03.001.

17. Adcock, I.M.; Barnes, P.J. Molecular mechanisms of corticosteroid resistance. Chest 2008, 134, 394-401, doi:10.1378/chest.08-0440.

18. Cho, Y.S.; Kim, T.-B.; Lee, T.-H.; Moon, K.A.; Lee, J.; Kim, Y.K.; Lee, K.Y.; Moon, H.B. Chlamydia pneumoniae infection enhances cellular proliferation and reduces steroid responsiveness of human peripheral blood mononuclear cells via a tumor necrosis factor-alpha-dependent pathway. Clin. Exp. Allergy 2005, 35, 1625-1631, doi:10.1111/j.1365-2222.2005.02391.x.

19. Bossé, M.; Chakir, J.; Rouabhia, M.; Boulet, L.P.; Audette, M.; Laviolette, M. Serum matrix metalloproteinase-9: Tissue inhibitor of metalloproteinase-1 ratio correlates with steroid responsiveness in moderate to severe asthma. Am. J. Respir. Crit. Care Med. 1999, 159, 596-602, doi:10.1164/ajrccm.159.2.9802045. 
20. Mautino, G.; Oliver, N.; Chanez, P.; Bousquet, J.; Capony, F. Increased release of matrix metalloproteinase9 in bronchoalveolar lavage fluid and by alveolar macrophages of asthmatics. Am. J. Respir. Cell Mol. Biol. 1997, 17, 583-591, doi:10.1165/ajrcmb.17.5.2562.

21. Rödel, J.; Prochnau, D.; Prager, K.; Pentcheva, E.; Hartmann, M.; Straube, E. Increased production of matrix metalloproteinases 1 and 3 by smooth muscle cells upon infection with Chlamydia pneumoniae. FEMS Immunol. Med. Microbiol. 2003, 38, 159-164.

22. Park, C.-S.; Lee, Y.S.; Kwon, H.-S.; Lee, T.; Kim, T.B.; Moon, K.A.; Yoo, B.; Moon, H.B.; Cho, Y.S. Chlamydophila pneumoniae inhibits corticosteroid-induced suppression of metalloproteinase-9 and tissue inhibitor metalloproteinase-1 secretion by human peripheral blood mononuclear cells. J. Med. Microbiol. 2012, 61 Pt 5, 705-711, doi:10.1099/jmm.0.036624-0.

23. Grzela, K.; Zagorska, W.; Krejner, A.; Litwiniuk, M.; Zawadzka-Krajewska, A.; Banaszkiewicz, A.; Kulus, M.; Grzela, T. Prolonged Treatment with Inhaled Corticosteroids does not Normalize High Activity of Matrix Metalloproteinase-9 in Exhaled Breath Condensates of Children with Asthma. Arch. Immunol. Ther. Exp. (Warszawa) 2015, 63, 231-237, doi:10.1007/s00005-015-0328-z.

24. Barbaro, M.P.F.; Spanevello, A.; Palladino, G.P.; Salerno, F.G.; Lacedonia, D.; Carpagnano, G.E. Exhaled matrix metalloproteinase-9 (MMP-9) in different biological phenotypes of asthma. Eur. J. Intern. Med. 2014, 25, 92-96, doi:10.1016/j.ejim.2013.08.705.

25. Wong, C.K.; Ho, C.Y.; Ko, F.W.; Chan, C.H.; Ho, A.S.; Hui, D.S.; Lam, C.W. Proinflammatory cytokines (IL17, IL-6, IL-18 and IL-12) and Th cytokines (IFN-gamma, IL-4, IL-10 and IL-13) in patients with allergic asthma. Clin. Exp. Immunol. 2001, 125, 177-183.

26. Zhang, Y.-L.; Luan, B.; Wang, X.-F.; Qiao, J.Y.; Song, L.; Lei, R.R.; Gao, W.X.; Liu, Y. Peripheral blood MDSCs, IL-10 and IL-12 in children with asthma and their importance in asthma development. PLoS ONE 2013, 8, e63775, doi:10.1371/journal.pone.0063775.

27. Xystrakis, E.; Kusumakar, S.; Boswell, S.; Peek, E.; Urry, Z.; Richards, D.F.; Adikibi, T.; Pridgeon, C.; Dallman, M.; Loke, T.K.; et al. Reversing the defective induction of IL-10-secreting regulatory T cells in glucocorticoid-resistant asthma patients. J. Clin. Investig. 2006, 116, 146-155, doi:10.1172/JCI21759.

28. Hawrylowicz, C.; Richards, D.; Loke, T.-K.; Corrigan, C.; Lee, T. A defect in corticosteroid-induced IL-10 production in T lymphocytes from corticosteroid-resistant asthmatic patients. J. Allergy Clin. Immunol. 2002, 109, 369-370.

29. Smith-Norowitz, T.A.; Chotikanatis, K.; Weaver, D.; Ditkowsky, J.; Norowitz, Y.M.; Hammerschlag, M.R.; Joks, R.; Kohlhoff, S. Chlamydia pneumoniae-induced tumour necrosis factor alpha responses are lower in children with asthma compared with non-asthma. BMJ Open Respir. Res. 2018, 5, e000239, doi:10.1136/bmjresp-2017-000239.

30. Vanders, R.L.; Gibson, P.G.; Wark, P.A.B.; Murphy, V.E. Alterations in inflammatory, antiviral and regulatory cytokine responses in peripheral blood mononuclear cells from pregnant women with asthma. Respirology 2013, 18, 827-833, doi:10.1111/resp.12068.

31. Shima, K.; Coopmeiners, J.; Graspeuntner, S.; Dalhoff, K.; Rupp, J. Impact of micro-environmental changes on respiratory tract infections with intracellular bacteria. FEBS Lett. 2016, 590, 3887-3904, doi:10.1002/18733468.12353.

32. Ren, J.; Sun, Y.; Li, G.; Zhu, X.-J.; Cui J-G. Tumor necrosis factor- $\alpha$, interleukin- 8 and eosinophil cationic protein as serum markers of glucocorticoid efficacy in the treatment of bronchial asthma. Respir. Physiol. Neurobiol. 2018, 258, 86-90, doi:10.1016/j.resp.2018.06.004.

33. Berry, M.A.; Hargadon, B.; Shelley, M.; Parker, D.; Shaw, D.E.; Green, R.H.; Bradding, P.; Brightling, C.E.; Wardlaw, A.J.; Pavord, I.D. Evidence of a role of tumor necrosis factor alpha in refractory asthma. N. Engl. J. Med. 2006, 354, 697-708, doi:10.1056/NEJMoa050580.

34. Boulay, M.-E.; Prince, P.; Deschesnes, F.; Chakir, J.; Boulet L-P. Metalloproteinase-9 in induced sputum correlates with the severity of the late allergen-induced asthmatic response. Respiration 2004, 71, 216-224, doi:10.1159/000077418.

35. Goleva, E.; Hauk, P.J.; Boguniewicz, J.; Martin, R.J.; Leung, D.Y.M. Airway remodeling and lack of bronchodilator response in steroid-resistant asthma. J. Allergy Clin. Immunol. 2007, 120, 1065-1072, doi:10.1016/j.jaci.2007.07.042.

36. Arno, G.; Kaski, J.C.; Smith, D.A.; Akiyu, J.P.; Hughes, S.E.; Baboonian, C. Matrix metalloproteinase-9 expression is associated with the presence of Chlamydia pneumoniae in human coronary atherosclerotic plaques. Heart 2005, 91, 521-525, doi:10.1136/hrt.2003.012054. 
37. Paolillo, R.; Iovene, M.R.; Romano Carratelli, C.; Rizzo, A. Induction of VEGF and MMP-9 expression by toll-like receptor 2/4 in human endothelial cells infected with Chlamydia pneumoniae. Int. J. Immunopathol. Pharmacol. 2012, 25, 377-386, doi:10.1177/039463201202500207.

38. Cataldo, D.D.; Tournoy, K.G.; Vermaelen, K.; Munaut, C.; Foidart, J.M.; Louis, R.; Noël, A.; Pauwels, R.A. Matrix metalloproteinase-9 deficiency impairs cellular infiltration and bronchial hyperresponsiveness during allergen-induced airway inflammation. Am. J. Pathol. 2002, 161, 491-498, doi:10.1016/S00029440(10)64205-8.

39. Chiba, N.; Shimada, K.; Chen, S.; Jones, H.D.; Alsabeh, R.; Slepenkin, A.V.; Peterson, E.; Crother, T.R.; Arditi, M. Mast cells play an important role in chlamydia pneumoniae lung infection by facilitating immune cell recruitment into the airway. J. Immunol. 2015, 194, 3840-3851, doi:10.4049/jimmunol.1402685.

40. Penttilä, J.M.; Anttila, M.; Puolakkainen, M.; Laurila, A.; Varkila, K.; Sarvas, M.; Mäkelä, P.H.; Rautonen, $\mathrm{N}$. Local immune responses to Chlamydia pneumoniae in the lungs of BALB/c mice during primary infection and reinfection. Infect. Immun. 1998, 66, 5113-5118.

41. Walsh, G.M. Biologics targeting IL-5, IL-4 or IL-13 for the treatment of asthma-An update. Expert Rev. Clin. Immunol. 2017, 13, 143-149, doi:10.1080/1744666X.2016.1216316.

42. Dominguez-Ortega, J.; Delgado, J.; Blanco, C.; Prieto, L.; Arroabarren, E.; Cimarra, M.; Henriquez-Santana, A.; Iglesias-Souto, J.; Vega-Chicote, J.M.; Tabar, A.I. Specific allergen immunotherapy for the treatment of allergic asthma: A review of current evidence. J. Investig. Allergol Clin. Immunol. 2017, 27(Suppl. 1), 1-35, doi:10.18176/jiaci.0149.

(C) 2020 by the author. Licensee MDPI, Basel, Switzerland. This article is an open access article distributed under the terms and conditions of the Creative Commons Attribution (CC BY) license (http://creativecommons.org/licenses/by/4.0/). 